\title{
15. CENOZOIC RADIOLARIA BIOSTRATIGRAPHY: LEG 30: TROPICAL AND EQUATORIAL PACIFIC
}

\author{
B.K. Holdsworth, The University, Keele, Staffordshire, England
}

\section{INTRODUCTION}

Well-preserved Cenozoic Radiolaria were recovered at all five sites drilled during Leg 30, though in two Holes-285 and 287-the Radiolaria-bearing sections were short. A very few Cretaceous Radiolarians were encountered in Holes $288 \mathrm{~A}$ and 289 , but in very poor preservation, and in view of the large volume of Cenozoic material for examination, these older occurrences have been ignored in the present investigation. By far the most important material is from Site 289, from which 110 contiguous Radiolaria-bearing cores were recovered, representing an almost complete paleontologic record from earliest late Eocene through Pleistocene.

Four of the five sites-286, 287, 288, 289-are tropical-equatorial, lying between $17^{\circ} 00^{\prime} \mathrm{S}$ and the Equator. Only Site 285 is at a significantly higher latitude. Sites 288 and 289 both lie within the area of the Ontong-Java Plateau.

The purpose of the investigation was to provide information on the distribution of Radiolaria taxa of known stratigraphic utility, though by no means have all such taxa been investigated. Practically no original paleontology is reported here. The results of a joint investigation by the present writer and B.M. Harker in attempting to gain information on fluctuations in Radiolaria dissolution at Sites 288-288A and 289 are reported separately in this volume.

\section{METHODS AND PRESENTATION OF RESULTS}

Radiolaria slides were prepared in the standard manner and frequencies of taxa determined in "regular" slides of the $>63 \mu$ fraction. Where time and material permitted, additional "coarse" slides of the $>150 \mu$ fraction were also prepared, together with "fine" slides of the $>63<150 \mu$ fraction. Such additional slides were used to assist in the detection of very rare taxa in most Site 289 section samples.

Frequencies of taxa recorded in tabulations are on the scale:

- Absent from all slides examined.

$\times$ Extremely rare. Not present in all regular slides examined, or present only in coarse or fine slide.

+ Very rare. Present, but less than three specimens in all regular slides examined.

$\mathrm{R}$ Rare. Three to 10 specimens per regular slide.

$\mathrm{F}$ Few. Eleven to 30 specimens per regular slide.

C Common. More than 30 specimens per regular slide.

A Abundant. More than 30 specimens could be found after searching only one or two fields at $60 \times$ magnification.

P Present. Frequency not determined.
It should be noted that the writer's " $\mathrm{C}$ " category is probably equivalent to the " $F$ " used by Riedel and Sanfilippo in earlier Initial Reports Volumes. " $X$ " is used where a taxon has not been detected but, for various reasons, cannot be reliably reported as "absent." Blanks in tabulations indicate that particular taxa have not been searched for, and exclamation marks indicate taxa believed to have been reworked or to be present due to contamination.

In some cases it is necessary to indicate that one taxon is significantly more abundant than another in a sample, even though both fall into the same conventional abundance bracket. In such cases the less-frequent taxon is recorded with a lowercase symbol. An x against a frequency symbol indicates that the taxon is probably significantly more abundant than reported, but that poor preservation prevents certainty.

Tabulations are presented for a selection of samples from all sites, with brief comments on lithology, abundance, preservation, paleontology, and zonation. The sequence of Radiolaria events at Site 289 is set out graphically (Figure 4) and used as the basis for a provisional biostratigraphic subdivision of the column. The writer's interpretations of all taxa tabulated are briefly indicated in the Paleontology section.

\section{ZONAL SYSTEM EMPLOYED}

Leg 30 Radiolaria assemblages have been allocated wherever possible to the zones of Riedel and Sanfilippo and Foreman (1973), conveniently summarized in Riedel and Sanfilippo (in press). Wherever possible the Site 289 sequence has been used as a standard for more precise estimation of relative ages of samples from other Leg 30 sites. Position relative to Site 289 can often be conveniently and precisely indicated by reference to one or more of the Ontong-Java segments (OS.1-35) defined below and wherever possible, the segment or segments with which a sample appears to correlate is indicated in conjunction with its zonal allocation. The applicability of the Riedel and Sanfilippo-Foreman zonal scheme to Leg 30 material is briefly discussed below.

\section{RADIOLARIANS AT EACH SITE}

Site 285: South Fiji Basin (lat $26^{\circ} 49.16^{\prime} \mathrm{S}$, long $175^{\circ} 48.24^{\prime} \mathrm{E}$; water depth $4658 \mathrm{~m}$ )

Radiolaria in biostratigraphically useful quantities are confined to a short segment at Site 285, Samples 285$2-5,126-128 \mathrm{~cm}$ through $285-4, \mathrm{CC}$. The richest faunas are those of Cores 2 and 3 in Radiolaria nanno oozes, brown, yellow, or green in color with variable volcanogenic content and very largely lacking planktonic foraminifera. 
Core 285-1 through Sample 285-2-4, 80-82 cm yielded only traces of orosphaerids and collosphaerids, or proved entirely barren. Traces only of Radiolaria, mainly collosphaerids and orosphaerids, were found from Core 285-5 to the base of Hole 285. In Hole 285A most processed samples proved barren or yielded only traces of spongodiscids, orosphaerids, and collosphaerids. A very slightly richer fauna with Saturnalis sp., Carpocanopsis ? sp. Stichocorys peregrina, and Lithopera bacca was found in $285 \mathrm{~A}-2, \mathrm{CC}$, but specimens are so excessively rare that the possibility of downhole reworking or sieve contamination must be taken into account.

\section{Zonal Allocation}

Preservation of Sections 285-2-5 through 285-4, CC faunas is only moderate, Cannartus and Ommatartus species in particular being both scarce and poorly preserved except for the robust "Cannartus pseudoprismaticus." Acrobotrys tritubus is present in Samples 285-2-5, 126-128 cm through 285-3-1, 120-122 $\mathrm{cm}$ and absent in 285-3-2, 80-82 $\mathrm{cm}$ through 285-4, CC, where only Acrobotrys sp. (two tubes) occurs. Lithopera bacca is common in all rich samples from the segment, Solenosphaera omnitubus is totally absent in all samples.

The rather monotonous sequence of assemblages in this probably slowly deposited segment, together with marked differences in degree of preservation of specimens within assemblages, suggests some upward reworking-confirmed by the nannofossils. Samples 285-4, CC through 285-3-1 fairly certainly belong to the Ommatartus antepenultimus Zone, OS.11-10. Samples 285-3-1 through 285-2-5 appear to belong to the $O$. antepenultimus Zone, OS.9-8. The suggested upward limit depends, however, upon the absence of $S$. omnitubus which has not been proved to exist at relatively high latitudes and is probably not to be expected (W.R. Riedel, personal communication). The persistence of $A$. tritubus to 285-2-5 suggests the sample to be no younger than the Stichocorys peregrina Zone, OS.6, presuming the specimens are not reworked.

The Stichocorys populations are curiously anomalous relative to known equatorial sequences. Compositions fluctuate, but the Stichocorys peregrina morphotype is more abundant than the Stichocorys delmontensis morphotype as low as $285-4, \mathrm{CC}$, where a totally $S$. delmontensis population would be expected. Further, all $S$. delmontensis are of "late" form in this hole, the "typical" form, to be expected at Os.10 levels, is completely absent. The 285-4, CC fauna would not, according to equatorial experience, be expected earlier than OS.6, but the Site 285 nannoplankton flatly denies that the sample can be this young. It can only be concluded that the $S$. delmontensis to $S$. peregrina transition occurs considerably earlier at relatively high latitudes. Kling (1971) was led to the same conclusion by an early occurrence of a Stichocorys peregrina population at $18^{\circ} 02.0^{\circ} \mathrm{N}$ in the Philippine Basin.

In thickness, depth, lithology, and faunal content the Radiolaria-rich 285 segment appears to compare very closely with that, at the adjacent Site 205 (Burns, Andrews, et al., 1973, p. 66) which was allocated entirely to the $S$. peregrina Zone (Table 1).

\section{Site 286: New Hebrides (lat $16^{\circ} 31.92$ 'S, long $166^{\circ} 22.18^{\prime} \mathrm{E}$; water depth $4465 \mathrm{~m}$ )}

Radiolaria faunas adequate for biostratigraphic purposes are patchily distributed in the column at Site 286, many samples revealing only traces of useful species or proving virtually barren. Throughout the greater part of

TABLE 1

Radiolaria at Site 285

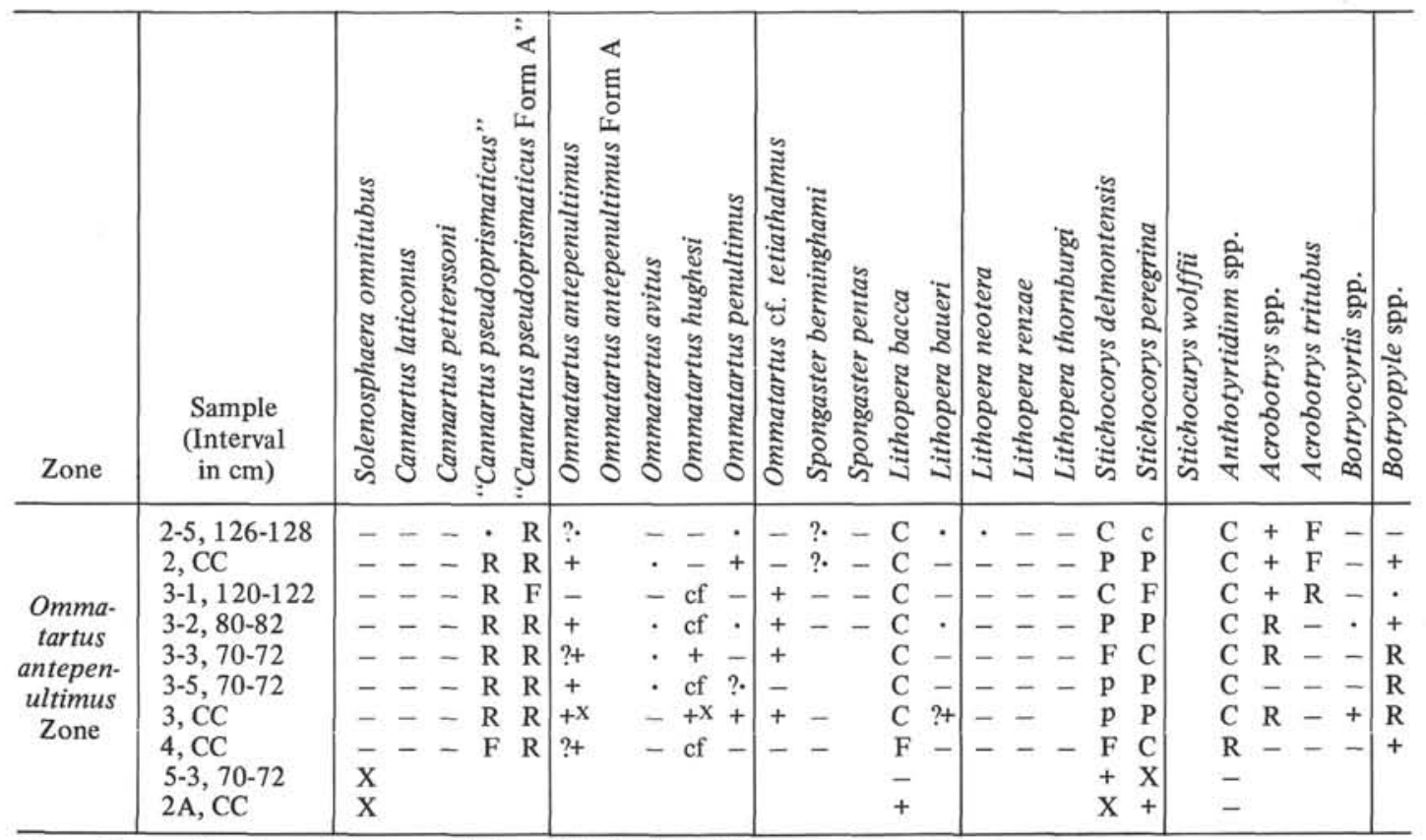

Note: For explanation of most symbols see Methods and Presentation of Results. $\mathrm{cf} .=$ Specimens with some similarities to species named. 
the hole even the richer assemblages are strongly diluted by volcanic glass, pumice, mineral grains, and siliceous aggregates so that slides are unsatisfactory. Tabulated frequencies cannot be directly compared with those recorded at other sites, as Site 286 samples yield far fewer specimens. Nevertheless, the apparent sequence of Radiolaria events detected proves to be in comparatively good agreement with that established at Site 289 wherever comparison between holes can be made (Figure 3). A short segment of the faunal sequence at Site 286 is unpreserved at Site 289 due to the EoceneOligocene vacuity, and at least the lowest 14 sedimentary cores of Site 286 equate with levels below the lowest level of Radiolaria-preservation at Site 289.

Among the Site 286 specimens processed, only Sample 286-1, CC yielded common Radiolaria. Cores 286-2 through 286-6 are essentially barren on the evidence of core-catcher samples, yielding only very occasional highly dissolved specimens. Absence of Radiolaria in this segment is probably due to solution associated with extreme water depth and very low depositional rates. Reasonably abundant but never common Radiolaria occur in Sections 286-7-2 through 286-12-2, though abundance is lower in Cores 9 and 10. In Samples 286-12, CC through 286-15, CC reasonably abundant specimens are confined to Sections 286-14-1 and 286-14-2. Comparatively rich faunas return in 286-17-1 through 28617-4. Samples from Sections 286-17-5 through 286-24, $\mathrm{CC}$ proved either barren or revealed very poor faunas, slightly richer samples occurring in 286-18-1 and 286-23, CC. Reasonably abundant Radiolaria are found in practically all samples of 286-25, CC through 286-30, CC. Sparse Radiolaria are present in 286-31-2 and 31, CC, 31-1 being barren, and these are the lowest useful faunas encountered in the hole.

Fluctuating abundance of Radiolaria below 286-6, $\mathrm{CC}$ is almost certainly due to variation in the degree of dilution by volcanic debris.

In Core 286-1 Radiolaria are preserved in ashy ooze; in 286-7, 286-8, and 286-9-2 in very slowly accumulated, brown nanno ooze; in 286-9, CC through 286-11, CC in more rapidly accumulated, brown nanno ooze and chalk, rich in volcanic glass. Lower in the hole Radiolaria are preserved in siltstones and sandstones, rich in volcanic debris, rapidly or very rapidly accumulated.

\section{Zonal Allocation}

Samples 286-31, CC through 286-21, CC belong to the Podocyrtis mitra. The lowest fauna is apparently above the range of Podocyrtis ampla, the highest apparently below the morphotypic base of Podocyrtis chalara. The true top of the P. mitra Zone is thus higher than 286-21, CC.

Sections 286-17-3 and 286-17-4 apparently represent a high level in the Podocyrtis chalara Zone, above the morphotypic top of P. mitra. The Podocyrtis goetheana Zone is apparently unrepresented and the species has not been recognized at Site 286 .

Samples 286-17-2 through 286-11, CC belong to the T. bromia Zone, OS.35. T. bromia Zone, OS.34 is represented by $286-10$, CC through 286-9-2. Sample 2868, CC apparently belongs to the T. bromia Zone, OS.33.

The base of the Theocyrtis tuberosa Zone, OS.32 apparently lies between 286-8, CC and 286-8-3. Core 286-7 belongs to $T$. tuberosa Zone, OS. 30 .

Sample 286-1, CC almost certainly belongs to the $\mathrm{Om}$ matartus tetrathalmus Zone, OS.1 (Table 2).

\section{Radiolaria Events and Paleontology}

The reliability of the positioning of Radiolaria events at Site 286 varies according to the abundance and diversity of the available faunas. Events are summarized in Figure 1, and an indication is given of the abundance of radiolarians immediately above and below the apparent level of each event.

Most important is the event sequence across the $T$. bromia Zone- $T$. tuberosa Zone boundary-a portion of the succession which frequently appears to be cut out by a discontinuity in DSDP holes (as at 289), to be uncored, or in which the record is confused by obvious reworking. At Site 286 the junction lies in a very slowly accumulated, deep-water ooze section (see Biostratigraphic Summary, Site 286).

As at Site 289, Cyclampterium is first detected below the morphotypic base of Lithocyclia angusta, but in contrast with 289, "typical" Cyclampterium milowi as interpreted in this report is absent from the uppermost $T$. bromia Zone and lowermost $T$. tuberosa Zone. Specimens lack the markedly elongate abdomen and perforate feet, and according to length of abdomen have been tabulated as either " $C$. cf. milowi" or "Cyclampterium cf pegetrum." The latter tend to have rather more weakly developed abdomens and more elongate feet than younger specimens included in this species.

\section{Site 287: Coral Sea Basin (lat $13^{\circ} 54.67^{\prime} \mathrm{S}$, long $153^{\circ} 15.93^{\prime} \mathrm{E}$; water depth $4632 \mathrm{~m}$ )}

The downward sequence of graded silts and claysgreen clay-brown clay-brown nanno ooze recovered in the upper 10 cores at this Site proved essentially devoid of Radiolaria. Traces of Radiolaria in 287-1, CC and 287-10, CC are quite inadequate for biostratigraphic purposes. The lowermost lithologic unit of yellowishgray nanno chalk, immediately below the OligoceneEocene discontinuity at $287-11-0,27 \mathrm{~cm}$, also proved to be barren of Radiolaria down to $287-11-2,40-42 \mathrm{~cm}$. Trace quantities of Radiolaria occur down to 287-11-4, $28-30 \mathrm{~cm}$ and rare, moderately preserved specimens were found in 287-11-5, 37-39 cm. Abundant wellpreserved radiolarians are present by 287-11-6, 28-30 $\mathrm{cm}$, and such rich, well-preserved assemblages persist at least through the next 6.9 meters to $287-12-4,70-72 \mathrm{~cm}$. Only traces of radiolarians are present by $287-12-5,70$ $72 \mathrm{~cm}$. From this point through the 31 meters to basement, only sporadic traces of extremely poorly preserved radiolarians were encountered.

The reason for restriction of common radiolarians to only a short segment of the nanno chalk is not wholly apparent. Smear-slide data reveal no correlation with 
TABLE 2

Radiolaria at Site $\mathbf{2 8 6}$

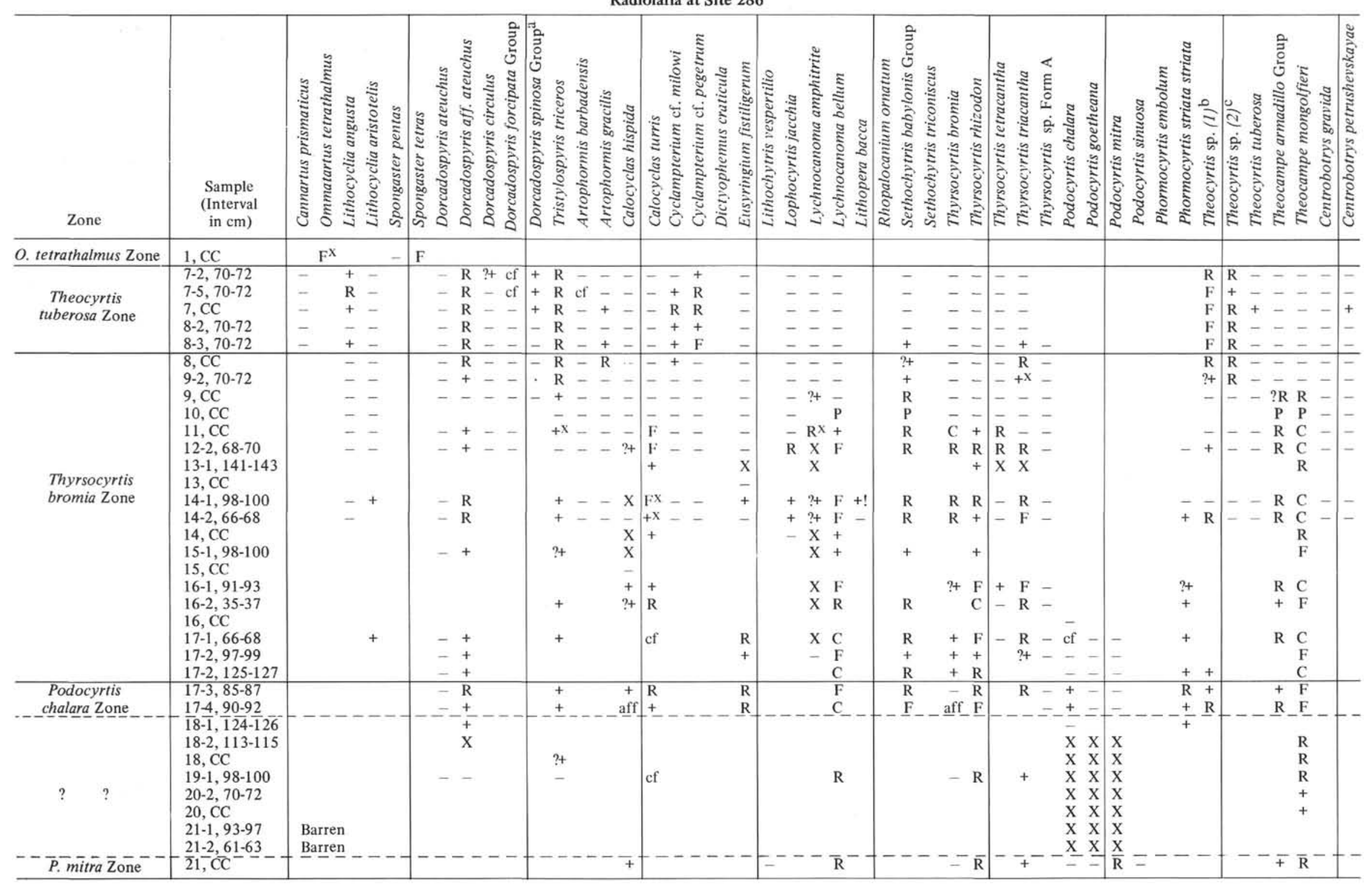




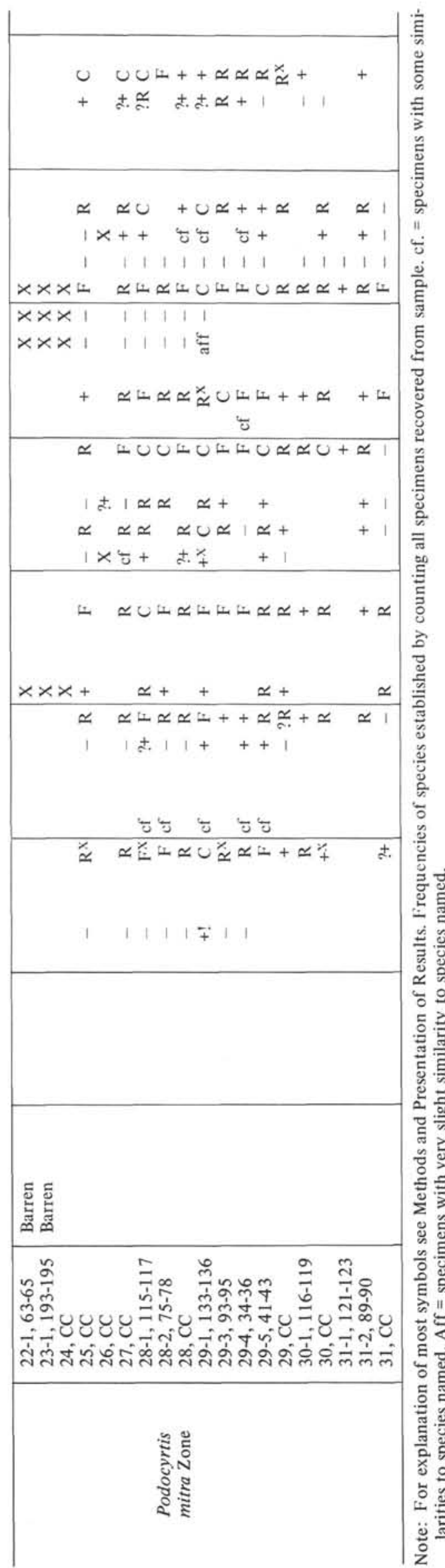

any nonbiogenic component and the lowest rich Radiolaria level is some 4.5 meters above the highest recorded chert in Core 287-13. Smear-slide data do, however, suggest an increase in sponge debris through the Radiolaria-rich segment, and it is possible that an increased mass of organic opal allowed silica saturation of pore water to be achieved during early diagenesis without dissolution of a signficant percentage of opaline fossils.

\section{Zonal Allocation}

The very poor fauna of Sample 287-14, CC contains Phormocrytis striata striata in the absence of Phormocyrtis striata exquisita and cannot, therefore (Foreman, 1973), be lower than the P. striata striata Zone, basal zone of the middle Eocene. It could well be considerably higher.

The tabulation of the biostratigraphically more important taxa in the rich segment of Sections 287-12-4 through 287-11-6 apparently shows the morphotypic base of Thyrsocyrtis triacantha and the virtual extinction of Thyrsocyrtis hirsuta hirsuta. There appears to be good agreement with Foreman's (1973) tabulation of Sections 94-22-4 through 94-21-2 (Foreman, 1973, p. 412), except that Theocampe mongolfieri is excessively and surprisingly scarce at Site 287 . In the very poor fauna of Sample $287-11-5,37-39 \mathrm{~cm}, T$. hirsuta tensa is still almost certainly numerically in excess of $T$. triacantha. If, therefore, following Foreman (1973, p. 412), the base of the T. triacantha Zone is taken at the evolutionary transition between $T$. hirsuta tensa and T. triacantha, then the entire Section 287-12-4 through 287-11-5 belongs to the immediately lower $T$. mongolfieri Zone.

At the adjacent DSDP Coral Sea site, Site 210, Radiolaria were found through some 50 meters of subOligocene nanno chalk, never, apparently, as abundant or well preserved as at Site 287 (Burns, Andrews, et al., 1973 , p. 380). The top of the Radiolaria-bearing segment is of $P$. mitra Zone, clearly younger than the uppermost radiolarian sediments of Site 287, and, judging by Leg 30 experience, of middle Eocene age-not late Eocene as indicated in Burns, Andrews, et al., 1973, p. 440. The lowest adequate fauna, that of $210-39, \mathrm{CC}$, is indicated to be of T. triacantha Zone (Burns, Andrews, et al., 1973 , p. 380 ). If so, relatively well-preserved Radiolaria at Site 210 are entirely younger than at Site 287 , but close comparison of the earliest faunas cannot be made (Table 3).

Site 288: Ontong-Java Plateau (lat $5^{\circ} 58.35^{\prime} \mathrm{S}$, long $161^{\circ} 49.53^{\prime} \mathrm{E}$; water depth $3000 \mathrm{~m}$ )

Radiolaria are preserved in gray to white foramnanno oozes and chalks, essentially similar to those encountered at the adjacent Site 289. However, the biostratigraphic range of Radiolaria-containing cores recovered at Site 288 is shorter than at Site 289 and the preservation and diversity of assemblages considerably poorer. At least four discontinuities occur within the Radiolaria-bearing column (see Site Report, Site 288).

The segment of Sections 288-1 through 288-5, CC yielded Radiolaria in abundances ranging from few to trace. Sections 288-6-1 through 288A-2, CC contain 


\begin{tabular}{|c|c|c|c|}
\hline O. tetrathalmus Zone & $1, \mathrm{CC}$ & $\mathrm{C}$ & $\mathrm{mb} . O$. tetrathalmus $S$. pentas $\Rightarrow S$. tetras $\mathrm{mt} . S$. peregrina $\mathrm{mt} . P$. prismatium \\
\hline 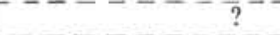 & $6, \mathrm{CC}$ & $\mathrm{B}$ & 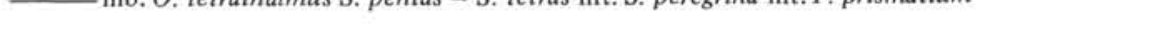 \\
\hline$-\cdots--\cdots$ & $7-2$ & $\mathrm{~F}$ & \\
\hline \multirow{4}{*}{$\begin{array}{l}\text { T. tuberosa } \\
\text { Zone }\end{array}$} & $7-5$ & $\mathrm{~F}$ & \\
\hline & $7, \mathrm{CC}$ & $\mathrm{F}$ & mb. C. petrushevskayae \\
\hline & $8-2$ & $\mathrm{~F}$ & mt. S. babylonis $\mathrm{mt}$. T. triacantha (2) grp. \\
\hline & $8-3$ & $\mathrm{~F}$ & mb. C. pegetrum var. mb. L. angusta \\
\hline \multirow{20}{*}{ T. bromia Zone } & $8, \mathrm{CC}$ & $\mathrm{F}$ & _ mb.C. milowi var. mb. A. gracilis \\
\hline & $9-2$ & $\mathrm{R}$ & ? $\mathrm{mt} . T$. armadillo $\mathrm{mt} . T$. mongolfieri ? mt. L. amphitrite mb. T. tuberosa mb. T. triacantha(2) \\
\hline & $9, \mathrm{CC}$ & $\mathrm{R}$ & mt. L. bellum mt. T. armadillo grp. \\
\hline & $10, \mathrm{CC}$ & $\mathrm{R}$ & - mt. C. turris mt. T. bromia $\mathrm{mt}$. L. amphitrite $\mathrm{mt}$. T. rhizodon $\mathrm{mt}$. $T$. tetracantha \\
\hline & $11, \mathrm{CC}$ & $\mathrm{F}$ & mt. L. jacchia ?mt. C. hispida T. triacantha $\Rightarrow T$. tetracantha \\
\hline & $12-2$ & $\mathrm{~F}$ & mb. L. amphitrite L. bellum $\Rightarrow$ L. amphitrite $\mathrm{mt} . T$. triacantha $(1)$ \\
\hline & $12, \mathrm{CC}$ & & \\
\hline & $13-1$ & $\mathrm{~T}$ & \\
\hline & $13, \mathrm{CC}$ & $\mathrm{R}$ & - $\mathrm{mt}$. E. fistilgerum \\
\hline & $14-1$ & $\mathrm{~F}$ & - mt.P. s. striata \\
\hline & $14-2$ & $\mathrm{~F}$ & - ?mb. L. amphitrite mb. L. jacchia \\
\hline & $14, \mathrm{CC}$ & $\mathrm{T}$ & \\
\hline & $15-1$ & $\mathrm{~T}$ & \\
\hline & $15, \mathrm{CC}$ & $\mathrm{R}$ & — mt. C. hispida \\
\hline & $16-1$ & $\mathrm{~F}$ & mb. T. tetracantha \\
\hline & $16-2$ & F & \\
\hline & $16, \mathrm{CC}$ & $\mathrm{R}$ & - $\mathrm{mt} . P$. cf. chalara \\
\hline & $17-1$ & $\mathrm{~F}$ & \\
\hline & $17-2$ & $\mathrm{~F}$ & \\
\hline & $\begin{array}{l}17-2 \\
17-3\end{array}$ & $\begin{array}{l}\mathrm{F} \\
\mathrm{F}\end{array}$ & - mb. T. bromia $\mathrm{mt}$. P. chalara \\
\hline \multirow{11}{*}{ ? } & $17-4$ & $\mathrm{~F}$ & $\longrightarrow$ mb $P$ chalara mb $T$ triceros mb Theocyrtis sp. mb $C$ turris \\
\hline & $17-5$ & $\mathrm{~T}$ & - mo. F. chatara mo. 1. triceros mo. Theocyrtis sp. mo. C. tarris \\
\hline & $18-1$ & $\mathrm{R}$ & mb. D. aff. ateuchus \\
\hline & $18-2$ & $\mathrm{~T}$ & - mo. $D$. ant. areucras \\
\hline & $18-3$ & $\mathrm{~T}$ & \\
\hline & $18, \mathrm{CC}$ & $\mathrm{T}$ & ? $\mathrm{mb}, T$ triceros \\
\hline & $19-1$ & $\mathrm{~T}$ & \\
\hline & $20-2$ & B & \\
\hline & $20, \mathrm{CC}$ & $\mathrm{T}$ & \\
\hline & $21-1$ & B & \\
\hline & $21-2$ & B & - mt.P. mitra \\
\hline \multirow{23}{*}{ P. mitra Zone } & $21, \mathrm{CC}$ & $\mathrm{R}$ & \\
\hline & $22-1$ & B & \\
\hline & $22-2$ & $\mathrm{~T}$ & \\
\hline & 23-1 & B & \\
\hline & $24, \mathrm{CC}$ & $\mathrm{T}$ & $-\mathrm{mt}$. L. vespertilio \\
\hline & $25, \mathrm{CC}$ & $\mathrm{F}$ & ? mt. S. triconiscus \\
\hline & $26, \mathrm{CC}$ & $\mathrm{T}$ & mt. R. cf. ornatum mt. P. embolum \\
\hline & $27, \mathrm{CC}$ & $\mathrm{F}$ & $? \mathrm{mt} . D$ craticula $\mathrm{mt}, R$ ornatum $\mathrm{mt}, S$, triconiscus \\
\hline & $28-1$ & $\mathrm{~F}$ & \\
\hline & $28-2$ & $\mathrm{~F}$ & \\
\hline & $28, \mathrm{CC}$ & $\mathrm{F}$ & \\
\hline & $29-1$ & $\mathrm{~F}$ & $? \mathrm{mb} T$ triceros \\
\hline & $29-3$ & $\mathrm{~F}$ & —?mb. T. triceros \\
\hline & $29-4$ & $\mathrm{~F}$ & mb. $T$ armadillo \\
\hline & $29-5$ & $\mathrm{~F}$ & mb, $D$, craticula mb $R$ ornatum \\
\hline & $29, \mathrm{CC}$ & $\mathrm{F}$ & ino. D. cratcata no. A. Ormatum \\
\hline & $30-1$ & $\mathrm{~F}$ & $\longrightarrow \mathrm{mb}$, C hispida \\
\hline & $30, \mathrm{CC}$ & $\mathrm{F}$ & \multirow{6}{*}{$\begin{array}{l}\text { mb. S. babylonis grp. mb. T. rhizodon mb. E. fistiligerum } \\
\text { mb.P. s. striata mb. S. triconiscus mb. P. embolum } \\
\text { mb. L. vespertilio mb.P. mitra mb. T. triacantha mb. L. bellum ?mb. C. hispida }\end{array}$} \\
\hline & $31-1$ & $\mathrm{~T}$ & \\
\hline & $31-2$ & $\mathrm{R}$ & \\
\hline & $31, \mathrm{CC}$ & $\mathrm{R}$ & \\
\hline & $33, \mathrm{CC}$ & $\mathrm{T}$ & \\
\hline & $35, \mathrm{CC}$ & $\mathrm{T}$ & \\
\hline
\end{tabular}

Figure 1. Radiolaria events and abundances at Site 286. $B=$ barren, $T=$ trace, $R=$ rare, $F=$ few, and $C=$ common. 
TABLE 3

Radiolaria at Site 287

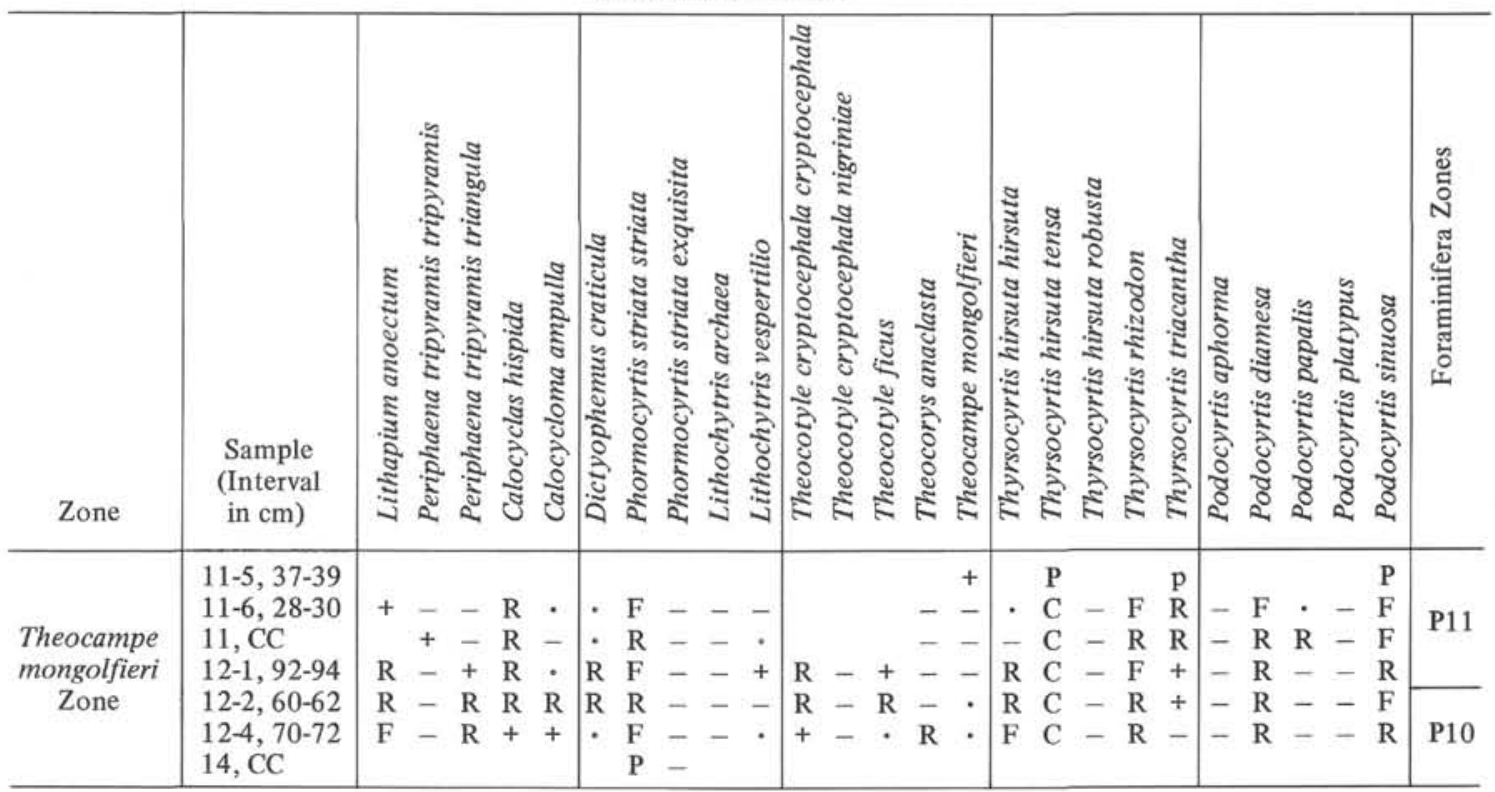

Note: For explanation of symbols see Methods and Presentation of Results.

considerably higher numbers of radiolarians, but compared to Site 289 preservation and diversity are poor. Sample 288A-3-1, 120-122 cm proved completely barren and only a few poorly preserved specimens were found in $288 \mathrm{~A}-3-2,51-53 \mathrm{~cm}$. Lower samples, down to 288A-51 , yielded comparatively abundant radiolarians, but only traces were found in Core 288A-6. Below this point in the hole, no biostratigraphically usable specimens were found, and most cores appear to be completely barren.

\section{Zonal Allocation}

Due to clearly apparent upward reworking of radiolarians, generally poor preservation, and the scarcity of even some usually commonly encountered species, detailed biostratigraphic subdivision of Holes 288-288A is impossible to achieve with any confidence. As a recourse Figure 2 has been constructed.

Positions of the 22 most reliably determined Radiolaria events in Holes 288-288A are indicated, together with the corresponding positions at Site 289 . Also indicated is the zonal range of the interval between each pair of events, as determined at Site 289 , so that a rough positioning is achieved of Holes 288-288A samples or sample sequences within zones. Positions of discontinuities in Holes 288-288A are those established on the basis of all available paleontologic information (see Site Report, Site 288).

Sample 288A-4, CC appears to be considerably older than the upper part of the core, and the base of the $D$. ateuchus Zone lies between the core catcher and 288A-42 . The very marked and sudden thinning relative to Site 289 strongly suggests a slight intracore discontinuity. Neither nannoplankton nor foraminifera confirms this conclusion. The nannoflora zonal position for Sample
$288 \mathrm{~A}-4, \mathrm{CC}$ is a level which, at Site 289 , lies within the D. ateuchus Zone: The foram zonal position for $288 \mathrm{~A}-$ 4-1 is a level which, at Site 289, lies within T. tuberosa Zone, OS.29. Presuming the highest-nanno-position for Sample 288A-4, CC to be the correct position, it appears that the Radiolaria and foram faunas truly contemporaneous with accumulation of Sample 288A-4, CC have been completely masked by older, upwardly reworked fossils. By analogy with 288-11, which lies above a clearly defined discontinuity and is heavily contaminated with older fossils of all three groups, it seems highly probable that a discontinuity immediately underlies Sample 288A-4, CC. If so, it appears to correlate with a segment at Site 289 throughout which dissolution of Radiolaria is particularly marked. This "solution anomaly" is numbered S.8A (Holdsworth and Harker, this volume, fig. 1).

Some further indications exist that discontinuities at Site 288 may correspond with solution anomalies at Site 289. Most striking is the coincidence between the truncation of the Site 288 Miocene column between Samples 288-6-1 and 288-5, CC and the beginning of solution anomaly S.3A in the latest Miocene of Site 289 (Holdsworth and Harker, this volume, fig. 1).

The relationships could be fortuitous. Nevertheless, it does seem possible that periods of increased opal dissolution in the essentially stable environment of the plateau surface (Site 289) were also periods of reduced accumulation, nonaccumulation, or erosion at the plateau margin (Site 288).

The extremely sparse fauna of Sample 288A-6-1, 76$78 \mathrm{~cm}$ indicates a position within T. tuberosa Zone, OS.31. Thus, the disappearance of Radiolaria in Hole $288 \mathrm{~A}$ occurs at a level slightly higher than the major $T$. bromia Zone/T. tuberosa Zone discontinuity at Site 289 . 


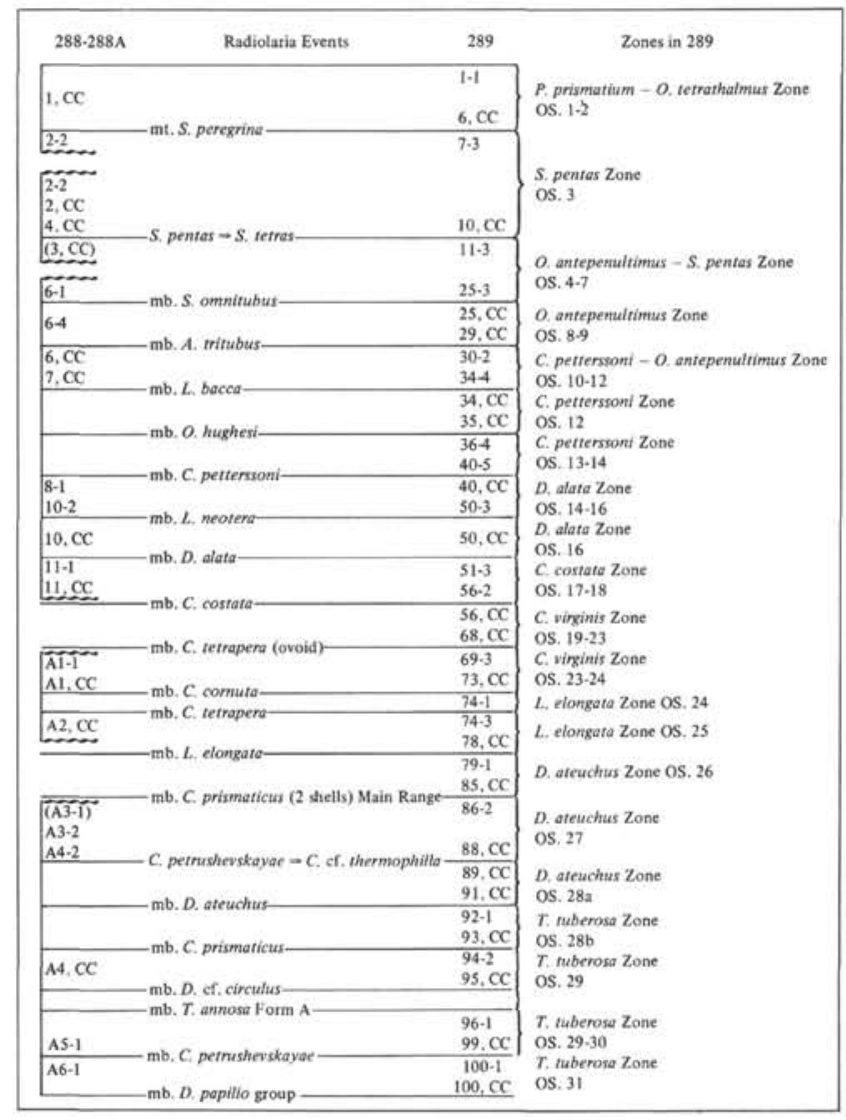

Figure 2. Correlation of Holes 288-288A with Site 289. (Note: Not to scale. Brackets indicate barren samples.)

Whether any part of the Radiolaria-bearing $T$. bromia Zone section of Site 289 is present at Site 288 cannot be determined, as no recovery was achieved between the Oligocene Core 288A-6 and the Paleocene Core 288A-8 (Table 4).

Site 289: Ontong-Java Plateau (lat $00^{\circ} 29.92$ 'S, long $158^{\circ} 30.69^{\prime} \mathrm{E}$; water depth $2206 \mathrm{~m}$ )

Radiolaria assemblages adequate for biostratigraphic purposes were found in all of the upper 110 continuous cores recovered at this site, with the exception of Core 289-109 which proved totally barren. Below 289-110-1 only traces of extremely poorly preserved Radiolaria were encountered at a few Cretaceous levels, apart from a rich $T$. bromia Zone assemblage downworked in a drilling sand of 289-112, CC.

Throughout this succession Radiolaria are preserved in gray to white nanno-foram oozes, chalks, and limestones. Down to Sample 289-107, CC abundance of Radiolaria, though subject to fluctuation, is high. Peak abundance is probably in Cores 289-103 and 289-104; the longest section showing consistently relatively low return per sample is Core 289-1 through Core 289-14. With very few marked exceptions, preservation and diversity of assemblages is good. A slightly more detailed discussion of abundance, preservation, and diversity of Radiolarians, is included in Holdsworth and Harker (this volume).
Between Samples 289-107, CC and 289-108-1, 72-75 $\mathrm{cm}$ there occurs a drastic change, taking place within an interval which is at maximum 14 meters and at minimum 0.72 meter, but most probably only slightly more than 6.0 meters. Radiolarians become very scarce and show corrosion and darkening. In Section 289-110-1 only fragmentary, robust species have survived and Core 289-109 revealed no evidence of radiolarians. Change in abundance, preservation, and diversity coincides rather closely with a sharp increase in the degree of chertification of rock recovered.

\section{Zonal Allocation}

In the time available for preparation of this report only a relatively small amount of the material from this hole has been examined. Most Radiolaria events considered in the investigation have been placed to within half a core, a minority can as yet be placed only within a core. Positions of zonal boundaries relative to individual cores are indicated in Table 5, and certain difficulties in the recognition of zonal boundaries are also discussed below.

The total zonal range of the Radiolaria-containing column is the Podocyrtis mitra Zone to Ommatartus tetrathalmus Zone. No assemblages diagnostic of the Podocyrtis chalara and Podocyrtis goetheana zones were recognized. If such assemblages exist (or existed) at Site 289 they must be confined to the interval between 289 110-1, 106-108 cm, P. mitra Zone, and 289-108-1, 72-75 $\mathrm{cm}, T$. bromia Zone, OS.35. This interval has a probable thickness of 19.25 meters, but the only available material is in Section 289-109-1, samples from which at $131-133 \mathrm{~cm}$ and $150-152 \mathrm{~cm}$ yielded no radiolarians. The only other zone unrecognizable in material from the upper 110 cores at Site 289 is that of Ommatartus penultimus (see below), but the very uppermost $T$. bromia Zone and very lowest $T$. tuberosa Zone levels are cut out by a discontinuity.

All Radiolaria events previously reported from tropical sediments of $T$. bromia Zone through $O$. tetrathalmus Zone and considered in this investigation proved detectable in Site 289 material. The event sequence determined is in good general agreement with that established in the adjacent but incompletely cored Hole 64 (Riedel and Sanfilippo, 1971).

\section{CORRELATION OF SITES 286 AND 289: RADIOLARIANS AT THE EOCENE-OLIGOCENE BOUNDARY}

Figure 3 shows the extent of agreement between the Radiolaria event sequences determined at Sites 286 and 289.

At Site 286, the first detected (latest Eocene) Cyclampterium specimens appear to be younger than the first examples seen at Site 289, as do the first-detected specimens of $A$. gracilis. The extinction of $L$. jacchia appears to be considerably earlier at Sites 286 than 289, while the extinctions of $L$. bellum and $P$. striata striata are considerably later. The latter species was not recognized at Site 289. Conversely Site 286 appears to lack C. azyx and Thyrsocyrtis sp. Form A. Important 
similarities are: (1) the first disappearance of $T$. triacantha prior to the extinction of $T$. tetracantha; (2) the closely spaced (perhaps coincident) disappearances of the other remaining Thyrsoc yrtis species and $C$. turris within the T. bromia Zone; (3) the reappearance of rare $T$. triacantha in the highest levels of the zone; and (4) the appearance of Cyclampterium species below the morphotypic base of L. angusta. Changes with time in the morphology of $T$. bromia are also comparable at the two sites

Asterisked events at Site 286 are those occurring between 101, CC and 102-1 at Site 289, where foram evidence points to a discontinuity involving at least Zones P17 and P18-and, therefore, spanning the Eocene-Oligocene boundary at Site 289 (Berggren, 1972). The spacing of these event levels through some 19 meters of probably very slowly deposited, glass-free nanno ooze at Site 286 suggests that the sequence is substantially more complete than at Site 289 . Some confirmation is afforded by a P18 Zone foram fauna in Core 286-8. In contrast to Site 287 and all other investigated sites of the neighboring Coral and Tasman seas (Edwards, 1973), as well as to Site 289, Site 286 appears to lack an Eocene-Oligocene discontinuity. The reason for the anomalously complete succession is not apparent. The clearly tropical nature of the Site 286 Radiolaria does not suggest that the Eocene latitude of the site was significantly different from those of adjacent Coral Sea sites where the discontinuity is well developed. Late Eocene through earliest Oligocene water depth was, however, probably greater at Site 286 than at sites where the discontinuity has been recognized.

Evidence from Sites 286 and 289 suggests that the level of the morphotypic base of $L$. angusta - taken here as the base of the T. tuberosa Zone-is coincident or nearly so with the level of the Eocene-Oligocene boundary as understood by foraminifera workers.

\section{APPLICABILITY OF ZONAL SCHEME TO LEG 30 MATERIAL}

In general, the zones outlines by Riedel and Sanfilippo (in press) and widely used in previous Initial Reports are readily recognizable in Leg 30 material. Certain difficulties were, however, encountered in placing zone boundaries, and these are summarized below.

Pterocanium prismatium Zone: P. prismatium is excessively scarce at Site 289 and was not encountered at other sites. It seems probable that this scarcity has led to the extinction level being placed rather lower at Site 289 than the level recorded at some previously investigated sites. The top of the $P$. prismatium Zone recorded in this account will, therefore, also be lower.

Spongaster pentas Zone: The base of this zone is defined as the level of first appearance of $P$. prismatium. At Site 289 the first definite $P$. prismatium detected is clearly at a level considerably higher than that of the first appearance at some previously investigated sites. In this account, therefore, the base of the $S$. pentas Zone (and of OS.4) is taken at the evolutionary transition from $S$. berminghami to $S$. pentas - the next highest datum indicated in Riedel and Sanfilippo (in press). Elsewhere, the morphotypic base of $P$. prismatium, and hence the base of the $S$. pentas Zone, appears to be considerably lower than this level-lower than the morphotypic top of A. tritubus (Sanfilippo and Riedel, 1974).

Stichocorys peregrina Zone: Placement of the upper boundary of this zone at Site 289 is subject to the problems outlined immediately above. The defined lower limit, the evolutionary transition from $S$. delmontensis to $S$. peregrina, was found difficult to place with confidence in the sequence of closely spaced samples.

Ommatartus penultimus Zone: The base of this zone has been defined as the level of evolutionary transition from $O$. antepenultimus to $O$. penultimus, the top as the level of evolutionary transition from $S$. delmontensis to $S$. peregrina. As such, it does not exist at Site 289 as an Ommatartus population with $O$. penultimus more abundant than $O$. antepenultimus is first seen at a level higher than that at which the Stichocorys transition is judged to occur.

The "blurring" of this zone at Site 289 may be at least partly attributable to reworking and scarcity of $\mathrm{Om}$ matartus spp. in what appears to be a segment of the column which has undergone considerable dissolution of opaline fossils. However, both in the Indian Ocean (Site 238) and elsewhere in the Pacific (Site 73, 77B) $O$. antepenultimus appears to remain dominant over $O$. penultimus up to the Stichocorys transition (Sanfilippo and Riedel, 1974).

Both the transitions currently considered to delimit this zone involve somewhat indistinct morphotypes, and the concept of OS.7 and OS.6 may provide a more satisfactory means for biostratigraphic division of this part of the equatorial succession.

Calocycletta virginis Zone: The true morphotypic base of $C$. virginis, the defined basal datum of this zone, cannot be located with confidence at either Sites 288 or 289 as the diagnostic feet are dissolved from all Calocycletta specimens through a considerable thickness of the column. The same problem has been encountered at other sites (A. Sanfilippo, personal communication) and the first appearance of Cyrtocapsella spp., taken here as the basal datum of OS.24, would probably provide a more consistently recognizable base for this zone. At Site 289, deposition of the lower half of the $C$. virginis Zone and the greater part of the underlying $L$. elongata Zone appears to have been accompanied by a relatively high degree of Radiolaria dissolution.

Dorcadorpyris ateuchus Zone: The defined upper limit of this zone-the morphotypic base of $L$. elongata-is clearly recognizable at Site 289 . The defined base, however-the evolutionary transition from $T$. triceros to $D$. ateuchus-is impossible to place with confidence. again, the anticipated position of the event is within a short segment where opal dissolution appears to have been relatively intense and where, probably as a result, Radiolarias faunas are restricted. At Site 289 the actual position of the $T$. triceros $\rightarrow D$. ateuchus transition could be a maximum of some 25 meters lower than the level at which it has been recorded. The scarcity of $D$. ateuchus at the bottom of its range has been noted at other sites (A. Sanfilippo, personal communication), and it is possible that the morphotypic base of $C$. prismaticus might provide a slightly more satisfactory basal datum 
TABLE 4

Radiolaria at Site 288

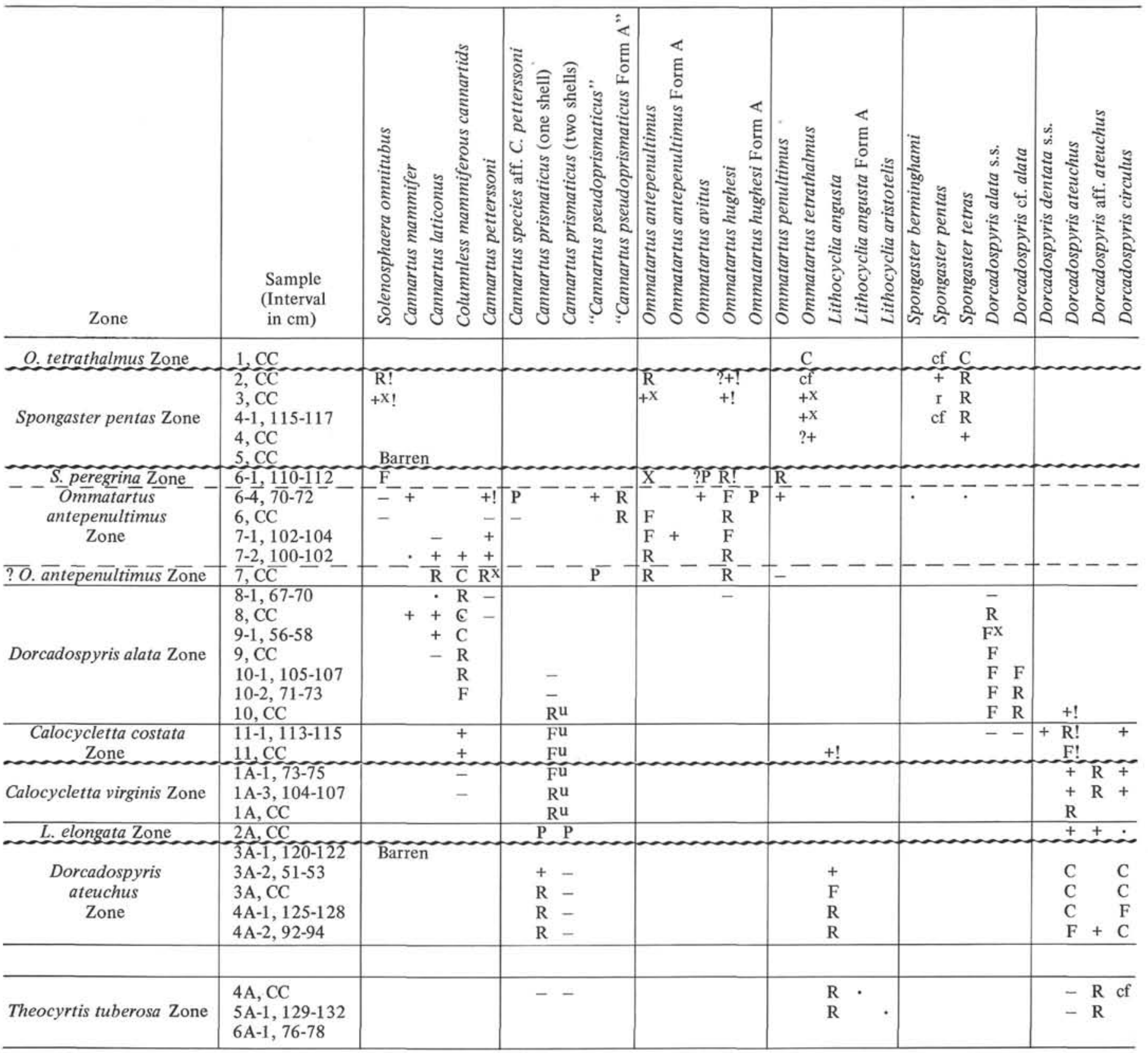

Note: For explanation of most symbols see Methods and Presentation of Results. $\mathrm{u}=$ varieties not differentiated; $\mathrm{cf}$. $=$ specimens with some similarities to species named; aff. = specimens with some very slight similarity to species named.

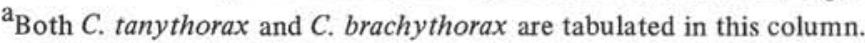

of the column headed "cores." Positions of events are represented by lines, and the sections, or core catchers, between which events can be placed are indicated above for the $D$. ateuchus Zone. Though $C$. prismaticus is also scarce at the bottom of its range, it is more readily identifiable than $D$. ateuchus in poorly preserved material. At Site 289 there is no overlap in the ranges of $T$. triceros and $D$. ateuchus (apparently seen at some previously investigated sites) and the position of the $T$. triceros to $D$. ateuchus transition is taken to be only some 20 meters above the morphotypic base of $C$. prismaticus.

Theocyrtis tuberosa Zone: The true base of this zone is present only at one of the Leg 30 sites, Site 286. Here, the base has been taken at the morphotypic first appearance of $L$. angusta rather than at the transition from $L$. aristotelis to L. angusta (Riedel and Sanfilippo, in press). L. aristotelis is scarcely detectable at Site 286. At Site 289 the species disappears abruptly slightly below the Eocene-Oligocene unconformity and prior to the morphotypic first appearance of $L$. angusta. It is not clear whether the species is genuinely present in association with $L$. angusta at the lowest preserved levels of the T. tuberosa Zone.

Podocyrtis goetheana Zone and Podocyrtis chalara Zone: Neither zone is detectable in material from Site 289 , perhaps due to a combination of poor recovery and 
TABLE 4 - Continued

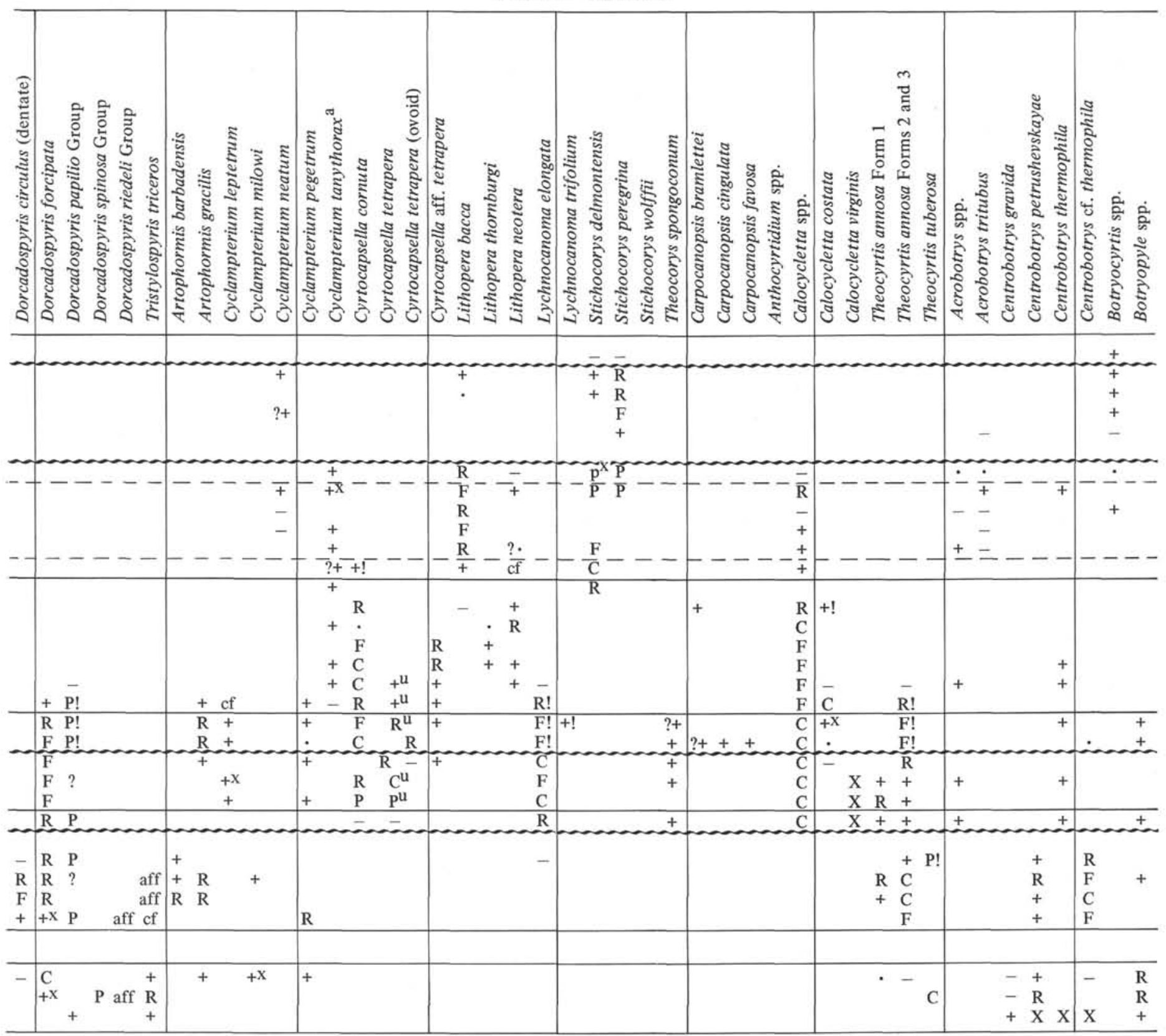

disappearance of Radiolaria between Cores 108-1 and 110-1. In the recovered material the first appearance of $P$. goetheana, in extremely low abundance, is higher than the base of the T. bromia Zone.

At Site 286 assemblages immediately below the level of first detection of $T$. bromia completely lack $P$. goetheana. The $P$. goetheana Zone would thus appear to be unrepresented at Site 286, and $P$. goetheana is absent from all recovered material. However, the 286 faunas are somewhat inadequate, and it is conceivable that the first detected $T$. bromia level is higher than the level of actual first appearance of the species. If so, the time equivalents of the $P$. chalara and $P$. goetheana zones would be the essentially barren sediments between Section 286-17-5 and Sample 286-21, CC.

\section{RADIOLARIA EVENTS AT SITE 289}

\section{Presentation}

Figure 4 is a graphic presentation of the positions of all Radiolaria events determined in the uppermost 110 cores of Site 289. Positioning of events is sometimes complicated by partial recovery failure. Where less than six sections were recovered in a barrel, the recovered sections are considered to come from the upper part of the cored interval, and the base of the lowest section is considered to be contiguous with the core catcher. Where a core catcher alone was recovered, it is considered to belong to the uppermost rather than the lowermost level of the interval cored. The approximate length of empty core barrel is represented in Figure 4 by dots at the side 
TABLE 5A

Radiolaria at Site 289

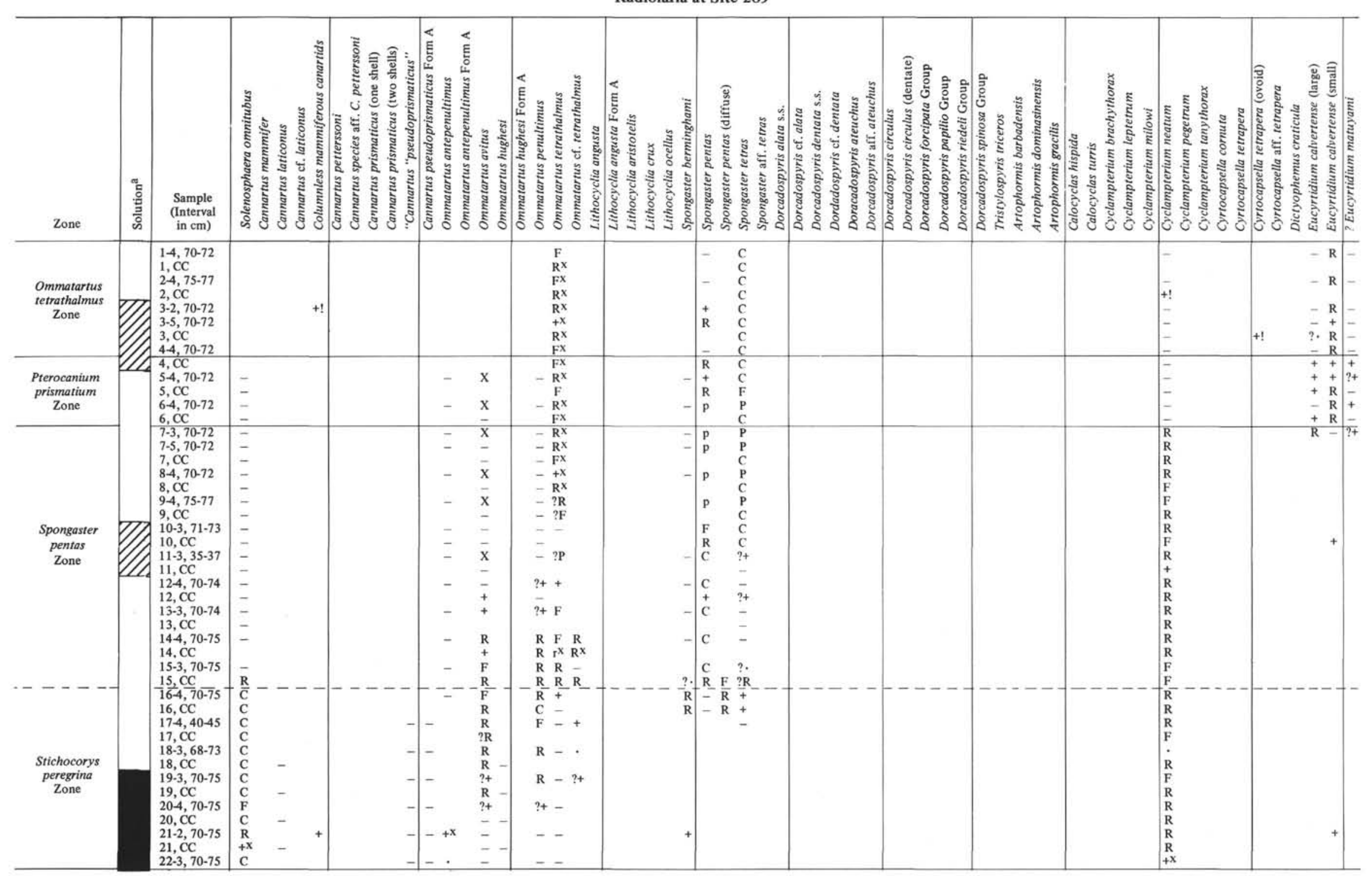




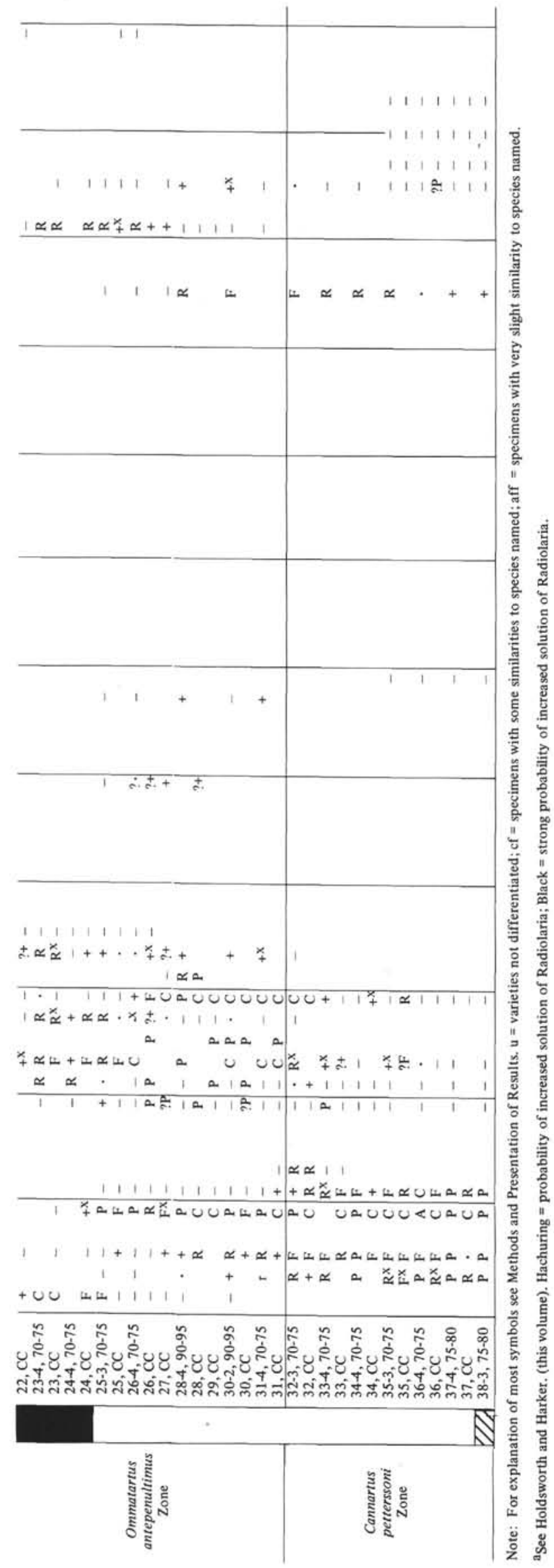

and below the lines. An "event line" is drawn approximately midway between the two samples. A reasonably clear visual impression is gained of the approximate thicknesses separating event levels in the hole.

Limits of foraminifera zones indicated were determined by T. Saito, and limits of time divisions are based on these zones (after Berggren).

\section{Types of Event}

Events recorded are essentially of the type recorded in earlier Initial Reports. The lowest and highest levels at which a taxon was detected are indicated "mb" (morphotypic base) and "mt" (morphotypic top), respectively. Where morphologic affinities between two taxa are such as to suggest that an ancestor-descendant relationship exists, the level at which the apparent descendant first becomes more abundant than the ancestral morphotype is considered to the the level of "evolutionary transition" (Riedel and Sanfilippo, 1971) and is indicated by an arrow.

No distinction is drawn between morphotypic and "morphotypic evolutionary" limits of taxa in the sense of Sanfilippo and Riedel (1973); Foreman (1973). In practice, a transition is considered to have occurred only when the descendant becomes at least some $30 \%$ more abundant than the ancestor.

Certain additional types of event are recorded. Some taxa prove to be very rare and of sporadic appearance at the top and/or bottom of their detectable range. In such cases, the absolute limits of range are recorded by " $\mathrm{mb}$ " and " $\mathrm{mt}$," and the limits of more abundant and consistent appearance are recorded " $\mathrm{mb} / \mathrm{mt}$... (main range)." For comparison between incompletely cored holes, or where faunas are sparse, it may sometimes be more realistic to consider the limits of main range rather than those of total range.

Where the final appearance of a taxon is suspected to be the result of upward reworking, the top is indicated "R." Where a taxon is possibly present lower than the level at which it was first definitely identified or higher than the level of last certain identification, the possible higher and lower limits are recorded "?mt/?mb."

A few taxa apparently have discontinuous ranges, thicknesses of consistent occurrence being separated by thicknesses in which the taxa are undetectable. In some such cases appearances and disappearances within the total range are indicated "mb/mt...(1), (2), etc."

Levels of marked change in the relative abundance of taxa which cannot be considered as levels of "evolutionary transition"-either because the taxa are not clearly related phylogenetically or because the change is seen to be reversible-are indicated "...... >...." (more abundant than) "............" (less abundant than). A level at which two species reach equal abundance is indicated "...... =....."

Following previous practice, an indication is given of the reliability of the positioning of each event-very good (VG), good $(\mathrm{G})$, moderate $(\mathrm{M})$, poor $(\mathrm{P})$, very poor (VP). The reliability grading takes into account the abundance of the taxon or taxa concerned at the apparent level of the event, the nature of occurrences prior 
TABLE 5A - Continued

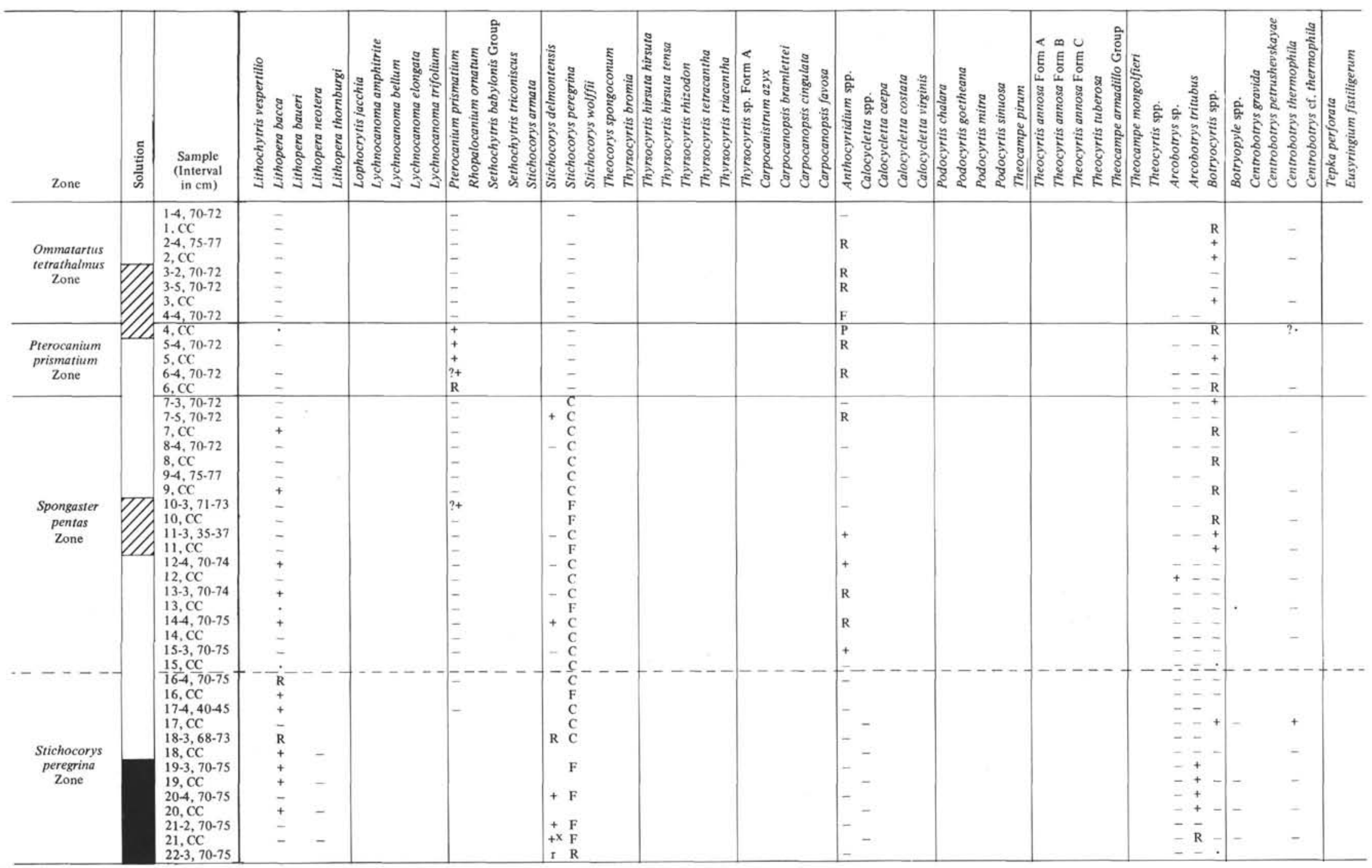




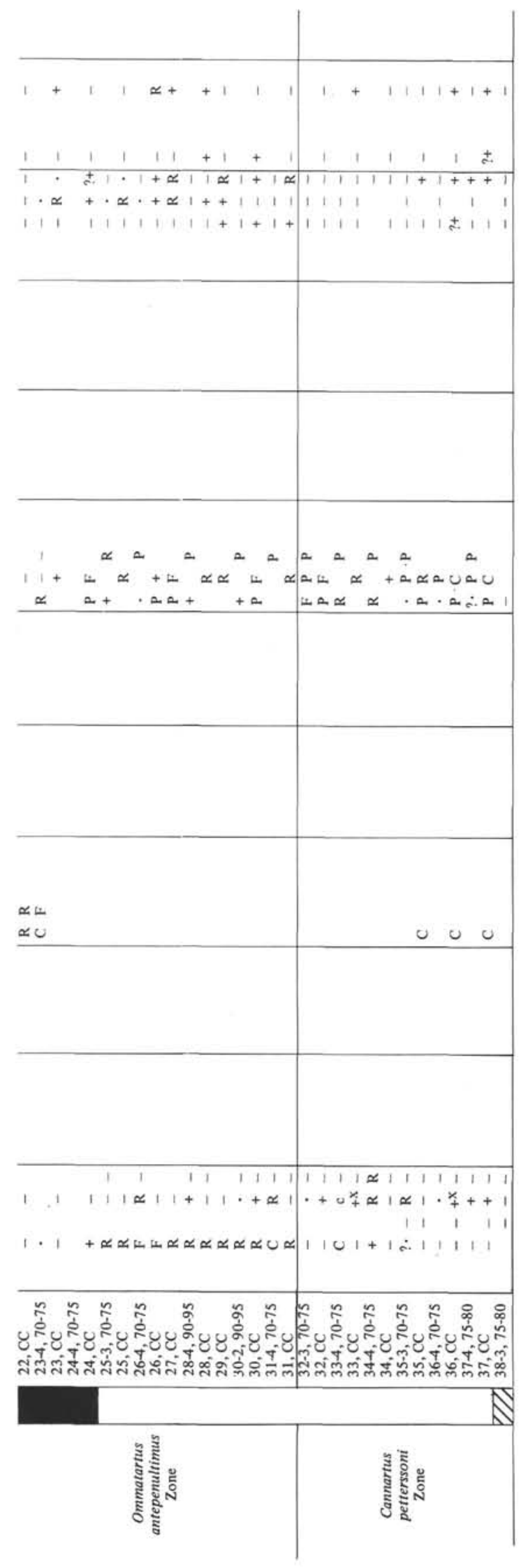

to apparent transition or extinction, the ease with which the taxon or taxa can be detected in a slide, and the distinctiveness of the taxa concerned.

Events chosen as basal datums for the informal divisions of the borehole are indicated by an asterisk.

\section{ONTONG-JAVA SEGMENTS: 0S.1-35}

The utility of Cenozoic Radiolaria in correlation of deep-sea sediment columns is now well established, and the Radiolaria zonation of tropical sediments developed by Foreman, Riedel, and Sanfilippo has found very general acceptance and proved to be relatively widely applicable. Certain difficulties of different kinds were, however, encountered during Leg 30 investigations.

Specific problems regarding faunal datums taken to define the limits of zones are mentioned above. Other problems arise in the presentation of biostratigraphic results. Most standard zones clearly have time values considerably greater than those of contemporaneous foram and nannoplankton zones, so that the simple positioning of a radiolarian assemblage within a zone provides only a broad assessment of its relative age. More precise statements are tortuous (e.g., "Dorcadospyris alata Zone higher than the morphotypic base of $C$. brachythorax but lower than the $L$. renzae to $L$. neotera transition"), largely incomprehensible to the nonspecialist and consequently, in the writer's brief experience, likely to be widely ignored. Precise and immediately comprehensible presentations of biostratigraphic results are possible only where fairly full information is available from more than one section, and diagrams can be constructed which compare the determined or estimated levels of particular faunal "events" in different columns (e.g., Figure 3). Spot samples and samples from very discontinuously cored holes are difficult to treat in this way, and the procedure is unsuitable for the rapid preparation of shipboard reports. A standard scheme of finer divisions seems desirable, based upon the Cenozoic Radiolaria "events" sequence and tied, wherever possible, to series and stages via the calcareous plankton.

Obvious problems exist in achieving such an ideal. Certain taxa of biostratigraphic value have relatively limited geographic distributions and some at least of the tropical-equatorial "events" appear to be diachronous. The full extent of such diachroneity between lowlatitude event sequences is still to be determined. Some taxa, otherwise useful, are so rare and/or so solution prone that their incorporation in a standard scheme would be unrealistic. Ideally, standard datums would delimit sediment sections accumulated during time periods of roughly comparable duration or of known relative duration, but the "time separations" of events are not easily estimated even in a relative way, based as such estimates must be on event spacings in columns of probably fluctuating accumulation rate. Some guidance may be expected in the future from statistical treatments of paleontologic and thickness data. Meanwhile, the most satisfactory recourse may be to regional schemes based upon chosen oceanic sections in which complications of reworking, solution, discontinuities, and accumulation fluctuations might be expected to be at a minimum. 


\begin{tabular}{|c|c|c|c|c|c|c|c|c|c|c|c|c|c|c|}
\hline Zone & 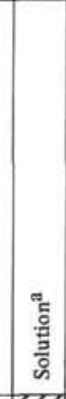 & $\begin{array}{c}\text { Sample } \\
\text { (Interval in cm) }\end{array}$ & 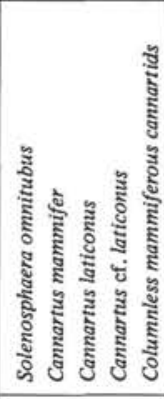 & 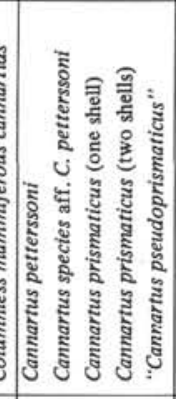 & 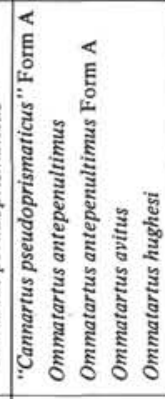 & 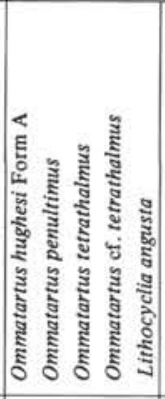 & 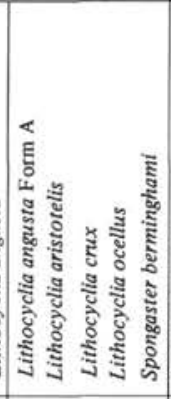 & 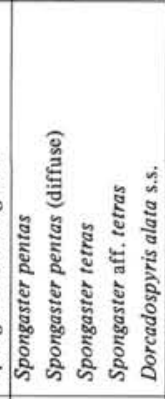 & 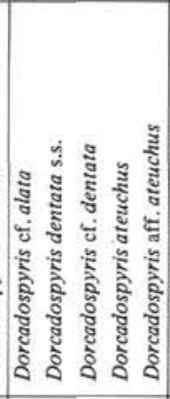 & 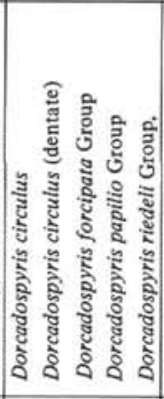 & 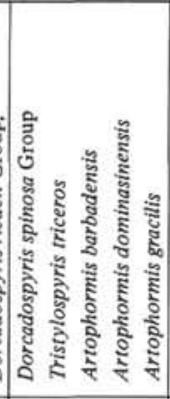 & 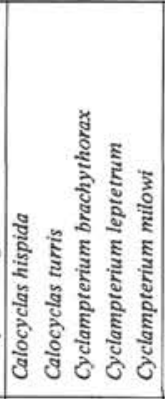 & 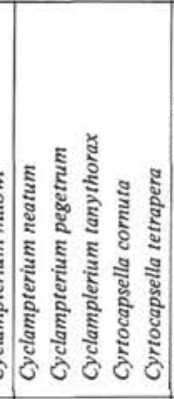 & 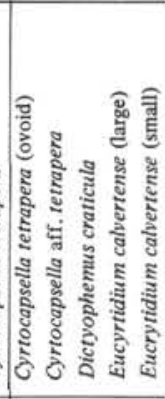 \\
\hline $\begin{array}{c}\text { Cannartus } \\
\text { petterssoni Zone }\end{array}$ & 8 & $\begin{array}{l}38-5,70-75 \\
38, \mathrm{CC} \\
39-3,70-75 \\
39, \mathrm{CC} \\
40-3,70-75 \\
40-5,70-75\end{array}$ & $\begin{array}{llll}\text { C } & \mathrm{FX}^{\mathrm{X}} & & \mathrm{P} \\
\mathrm{R} & \mathrm{F}^{\mathrm{X}} & & \mathrm{A} \\
\mathrm{F} & \mathrm{F} & & \mathrm{A} \\
\mathrm{F} & \mathrm{R} & \mathrm{R} & \mathrm{C} \\
\mathrm{R} & & & \mathrm{P} \\
\mathrm{P} & \mathrm{P} & & \mathrm{P} \\
\end{array}$ & + & $\begin{array}{ll}- & - \\
- & - \\
& -\end{array}$ & & 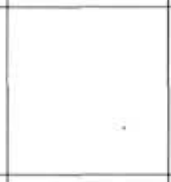 & $\begin{array}{l}- \\
- \\
-\end{array}$ & & & & $\begin{array}{l}+ \\
?+ \\
+- \\
\end{array}$ & $\begin{array}{lll}+ & - & - \\
- & - & - \\
\mathrm{R} & - & - \\
? \mathrm{R} & - \\
\mathrm{R} & \mathrm{C} & - \\
\mathrm{V} & \mathrm{C} & -\end{array}$ & $\begin{array}{l}-- \\
-- \\
-- \\
- \\
- \\
-\end{array}$ \\
\hline $\begin{array}{c}\text { Dorcadospyris } \\
\text { alata Zone }\end{array}$ & 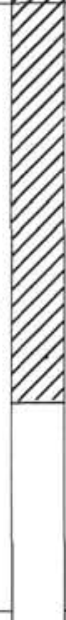 & $\begin{array}{l}40, \mathrm{CC} \\
41-1,70-75 \\
41, \mathrm{CC} \\
42-4,70-75 \\
42, \mathrm{CC} \\
43, \mathrm{CC} \\
44-3,70-75 \\
4-4-5,70-75 \\
44, \mathrm{CC} \\
45-3,70-75 \\
45, \mathrm{CC} \\
46, \mathrm{CC} \\
47-3,70-75 \\
47-5,70-75 \\
47, \mathrm{CC} \\
48-3,70-75 \\
48-5,70-75 \\
48, \mathrm{CC} \\
49-3,70-75 \\
49-5,70-75 \\
49, \mathrm{CC} \\
50-3,70-75 \\
50, \mathrm{CC} \\
\end{array}$ & 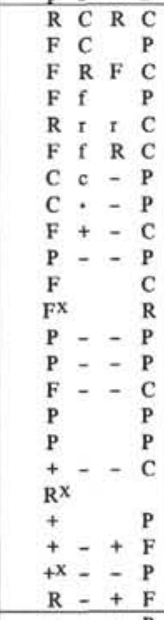 & : & $\begin{array}{c}+?+ \\
+ \\
+ \\
\text { R+ } \\
: \\
-\end{array}$ & & & $\begin{array}{l}- \\
\\
\mathrm{R} \\
\dot{ } \\
\dot{+} \\
+ \\
? \\
+ \\
\mathrm{R} \\
+ \\
+ \\
\mathrm{R} \\
+ \\
+ \\
\mathrm{R} \\
+ \\
\mathrm{R} \\
\mathrm{F} \\
+ \\
+ \\
\mathrm{C} \\
+\mathrm{X} \\
\mathrm{F}\end{array}$ & $\begin{array}{l}- \\
- \\
- \\
- \\
- \\
- \\
- \\
- \\
-\end{array}$ & $\begin{array}{l}- \\
\\
- \\
? \cdot \\
? \cdot \\
- \\
?+ \\
\text { aff }\end{array}$ & & $\begin{array}{c}- \\
-\cdot \\
- \\
- \\
\cdot- \\
? \mathrm{P} \\
\cdot \\
\mathrm{P} \\
+ \\
+ \\
+\mathrm{P} \\
\mathrm{X} \\
\mathrm{P} \\
+\mathrm{x} \\
+ \\
+\mathrm{X} \\
? \mathrm{R} \\
+ \\
+ \\
\mathrm{X}\end{array}$ & 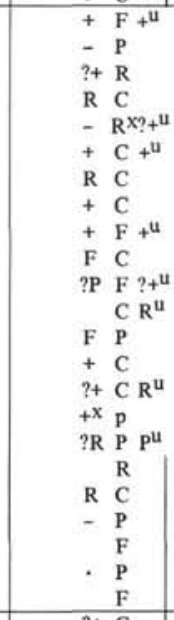 & $\begin{array}{ll} & + \\
+ \\
\text { R } \\
+ \\
+ \\
+ \\
+ \\
\text { R } \\
\text { F } \\
\text { P } \\
\text { R } \\
\text { F } \\
\text { P } \\
\text { C } \\
\text { F } \\
\text { P } \\
\\
\text { F } \\
\text { C } \\
+ \\
\text { R } \\
? . \\
-\end{array}$ \\
\hline \multirow[t]{2}{*}{$\begin{array}{l}\text { Calocycletta } \\
\text { costata Zone }\end{array}$} & & \begin{tabular}{|l}
$51-3,70-75$ \\
$51-5,70-75$ \\
$51, \mathrm{CC}$ \\
$52-3,70-75$ \\
$52-5,70-75$ \\
$52, \mathrm{CC}$ \\
$53-3,70-75$ \\
$53, \mathrm{CC}$ \\
$54-3,70-75$ \\
$54, \mathrm{CC}$ \\
$55-3,70-75$ \\
$55, \mathrm{CC}$ \\
$56-2,70-75$ \\
\end{tabular} & 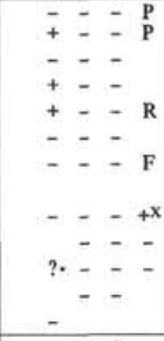 & $\begin{array}{l}\overline{-} \\
- \\
\overline{-} \\
- \\
- \\
- \\
++^{\mathrm{u}} \\
\mathrm{R}^{\mathrm{u}} \\
\mathrm{R}^{\mathrm{u}} \\
+\mathrm{x}^{\mathrm{u}} \\
+\mathrm{x}^{\mathrm{u}} \\
\mathrm{R}^{\mathrm{u}}\end{array}$ & & & & $\begin{array}{l}\overline{-} \\
\overline{-} \\
- \\
- \\
- \\
-\end{array}$ & 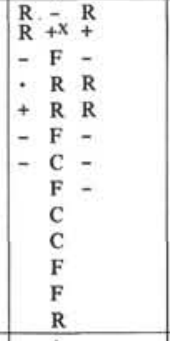 & $\begin{array}{l}\text { aff } \\
+x \\
+x \\
+x \\
+x \\
R \\
+x \\
\text { R } \\
+ \\
R \\
R \\
R \\
+x \\
\text { R } \\
?+ \\
?+\end{array}$ & & $\begin{array}{l}+\mathrm{X} \\
+\mathrm{X} \\
\mathrm{X} \\
\\
? \mathrm{R} \\
\mathrm{R} \\
\mathrm{X} \\
+\mathrm{x} \\
\mathrm{X} \\
. \mathrm{x} \\
\mathrm{X} \\
\mathrm{R} \\
\mathrm{X} \\
. \mathrm{x} \\
. \mathrm{P}\end{array}$ & $\begin{array}{r}?+\mathrm{C} \\
?+\mathrm{P} \\
\mathrm{F} \\
?+\mathrm{C} \\
\mathrm{C} \\
\text { ? } \mathrm{P} \\
\mathrm{F} \\
\text { F } \mathrm{C} \\
\mathrm{C} \\
\mathrm{C} \\
\mathrm{C} \\
\mathrm{C}\end{array}$ & $\begin{array}{r}\mathrm{F} \\
+ \\
+ \\
\mathrm{R} \\
\mathrm{R} \\
\mathrm{R} \\
\mathrm{R} \\
+ \\
+ \\
\mathrm{F} \\
+ \\
+ \\
+ \\
+ \\
+\end{array}$ \\
\hline & & $\begin{array}{l}56, \mathrm{CC} \\
57-3,70-75\end{array}$ & $-{ }^{-+}$ & $\mathrm{R}^{\mathrm{u}}$ & & & & & $\begin{array}{l}+ \\
\mathrm{R}\end{array}$ & $\begin{array}{l}+ \\
. x\end{array}$ & & $\mathrm{X}$ & $\begin{array}{l}\mathrm{C} \\
\mathrm{P}\end{array}$ & $t^{+u}-$ \\
\hline
\end{tabular}




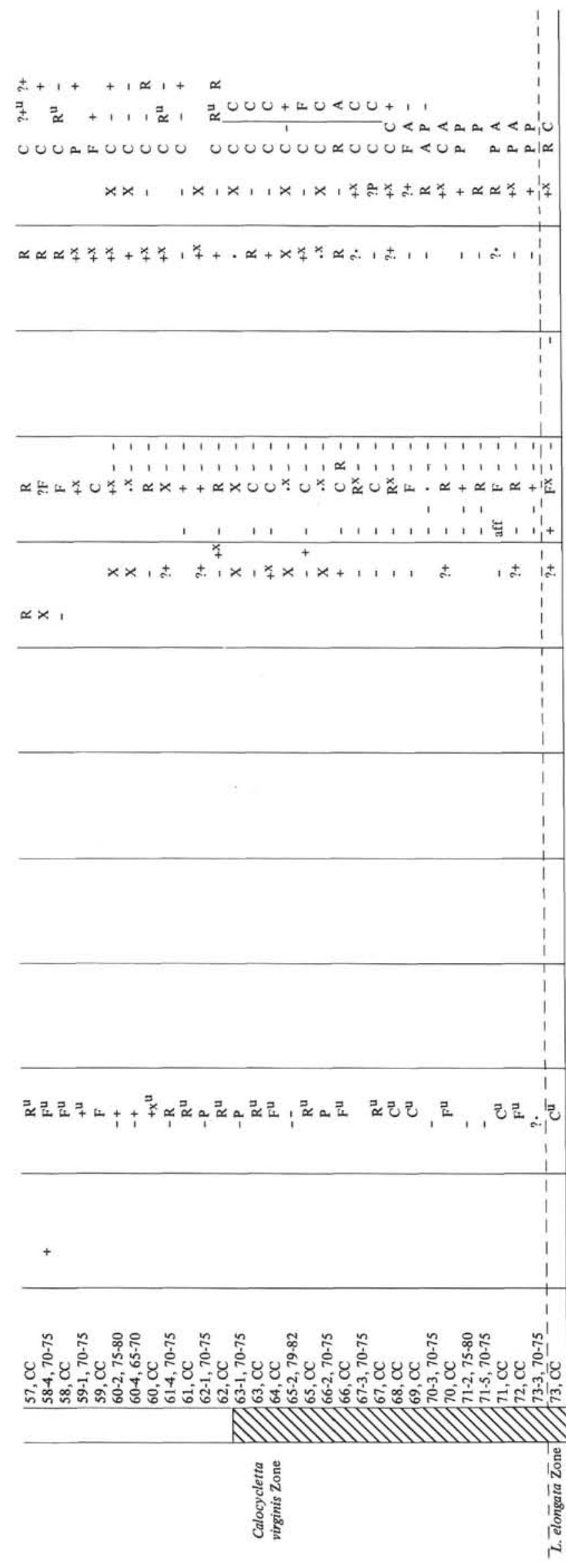

For the equatorial regions of the Pacific, at least, it seems likely that the Site 289 Ontong-Java sequence, when fully and expertly investigated, will provide an excellent "reference section" of this type for the late Eocene through Miocene. The Plio-Pleistocene record is less satisfactory in detail. The provisionally determined event sequence is set out in Figure 4. Events marked with an asterisk are those suggested as datums to delimit 35 provisional divisions of the late Eocene through Pleistocene sediment column and referred to as "Ontong-Java Segments" (OS.1-35). Choice of datum levels has been governed by the convenience of spacing and the distinctiveness of the events as observed in sample sequences of comparatively close spacing. Some are less satisfactory than others. Wherever possible, bases of standard Radiolaria zones have been made to coincide with segment bases, so that the majority of segments can be considered as locally developed, informal subzones. Relative thicknesses of segments, apparent relationships to Radiolaria and foram zones and to series and stages, can be found on Figure 4. Only a few comments are necessary.

OS.1:

OS.4:

OS.6-7:

OS.9:

OS.10:

OS.13: $\quad$ Again, the defined base of the segment appears to be very close indeed to the base of the $C$. petterssoni Zone, but differences of opinion could well exist regarding the position of the earliest $C$. petterssoni at Site 289.

OS.22: Assemblages of this segment are distinct in showing $C$. tetrapera in considerable abundance, with the ovoid form much more common than the nonovoid morphotype. C. tetraperarich levels do exist above OS.22 in the Ontong-Java Plateau sequence (Riedel and Sanfilippo, 1971, table 3A), but such higher occurrences should be clearly distinguishable by the presence of $C$. costata and/or D. dentata or $D$. altata.

OS.24: The relationship between the base of this segment and the base of the $C$. 


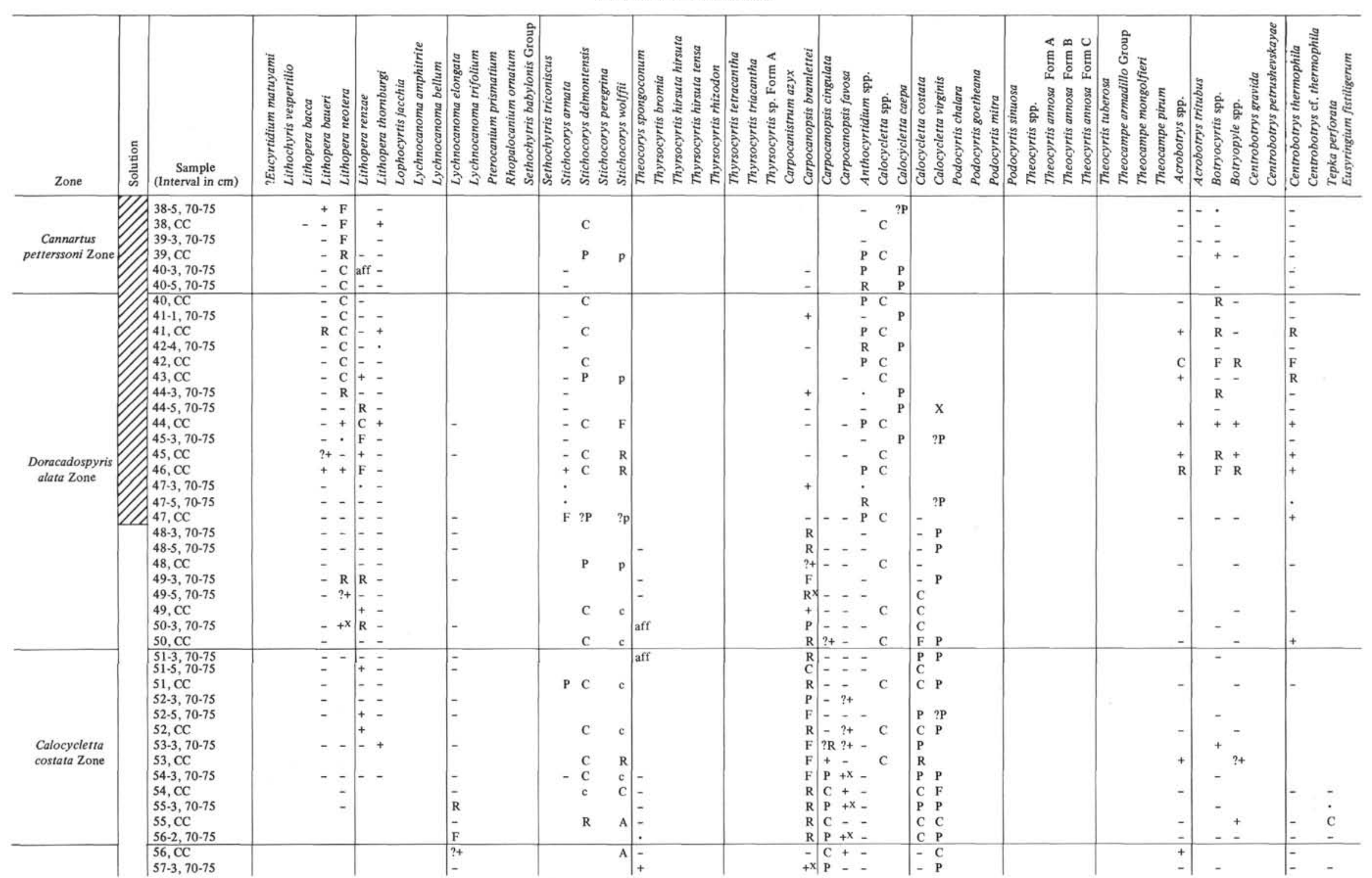




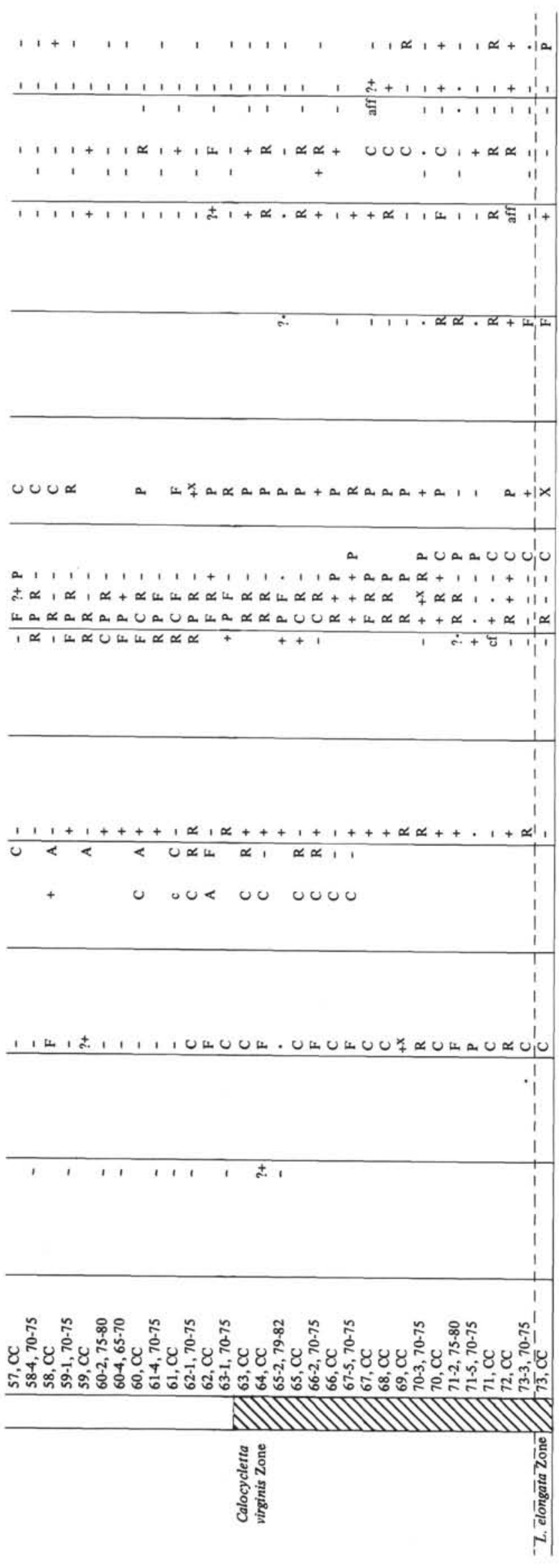

virginis Zone has been previously discussed. The defined basal datum of the segment is a "poor" event due to the scarcity of $C$. tetrapera at its earliest level, but frequency is "common" approximately 3 meters higher.

OS.27: The higher part of the segment is apparently strongly dissolved and the position of the L. angusta $\rightarrow C$. prismaticus datum defining the top may be governed by a diminution of solution effects.

OS.28a-28b: OS.28 apparently straddles the $T$. tuberosa Zone/ D. ateuchus Zone boundary and the junction between subsegments is drawn at the very uncertainly placed base of the latter zone.

OS.32 and 33: The diagnostic assemblages of these segments are, respectively: L. angusta unassociated with Centrobotrys spp.; Cyclampterium milowi unassociated with $L$. angusta. Due to the combined effects of the Eocene/Oligocene discontinuity and poor recovery, both assemblages are represented by only single samples-289-101, CC and 289 102-1, 91-95 cm, respectively.

OS.35 Poor recovery prevents a precise positioning of the upper datum-the extinction of $T$. bromia. Six other extinctions could be coincident or nearly so with the upper limit of $T$. bromia (Fig. 4). Three of these extinctions-of $C$. turris $T$. rhizodon and $T$, tetracantha-were found by Foreman, (1973) to occur within 5 meters of the T. bromia extinction. The top of OS.35 may mark virtually the final appearance of the genus Thyrsocyrtis in equatorial successions.

\section{PALEONTOLOGY}

Listed below are all taxa for which ranges have been recorded in Leg 30 samples. The original author is named and the figure or figures considered representative of each taxon and used for identification of Leg 30 specimens is indicated. Comments on definitions and ranges of taxa are added in some cases. Generic allocations are those that have most recently been used in reports of DSDP material and that are probably most familiar to the majority of Radiolaria workers. Attention is centered upon the definition of species morphotypes likely to be of practical value in comparing the relative ages of sediment samples. Possible phylogenetic relationships between these morphotypes and questions of supraspecific classification are very largely ignored.

\section{Solenosphaera omnitubus Riedel and Sanfilippo}

Riedel and Sanfilippo, 1971, plate 1B, fig. 23, 24.

This species is interpreted in the original sense of Riedel and Sanfilippo (1971). As far as can be determined the range is not significantly different, if at all, from the combined ranges of Solenosphaera omnitubus omnitubus plus Solenosphaera omnitubus procera (see Sanfilippo and Riedel, 1974).

This species is apparently absent at Site 285 and at other relatively high latitude sites (S.A. Kling and W.R. Riedel, personal communication). At Site 289 the first appearance of the species is nearly coincident in the late Miocene with a marked increase in abundance of all collosphaerids (Holdsworth and Harker, this volume), and it is 
TABLE 5C

Radiolaria at Site 289

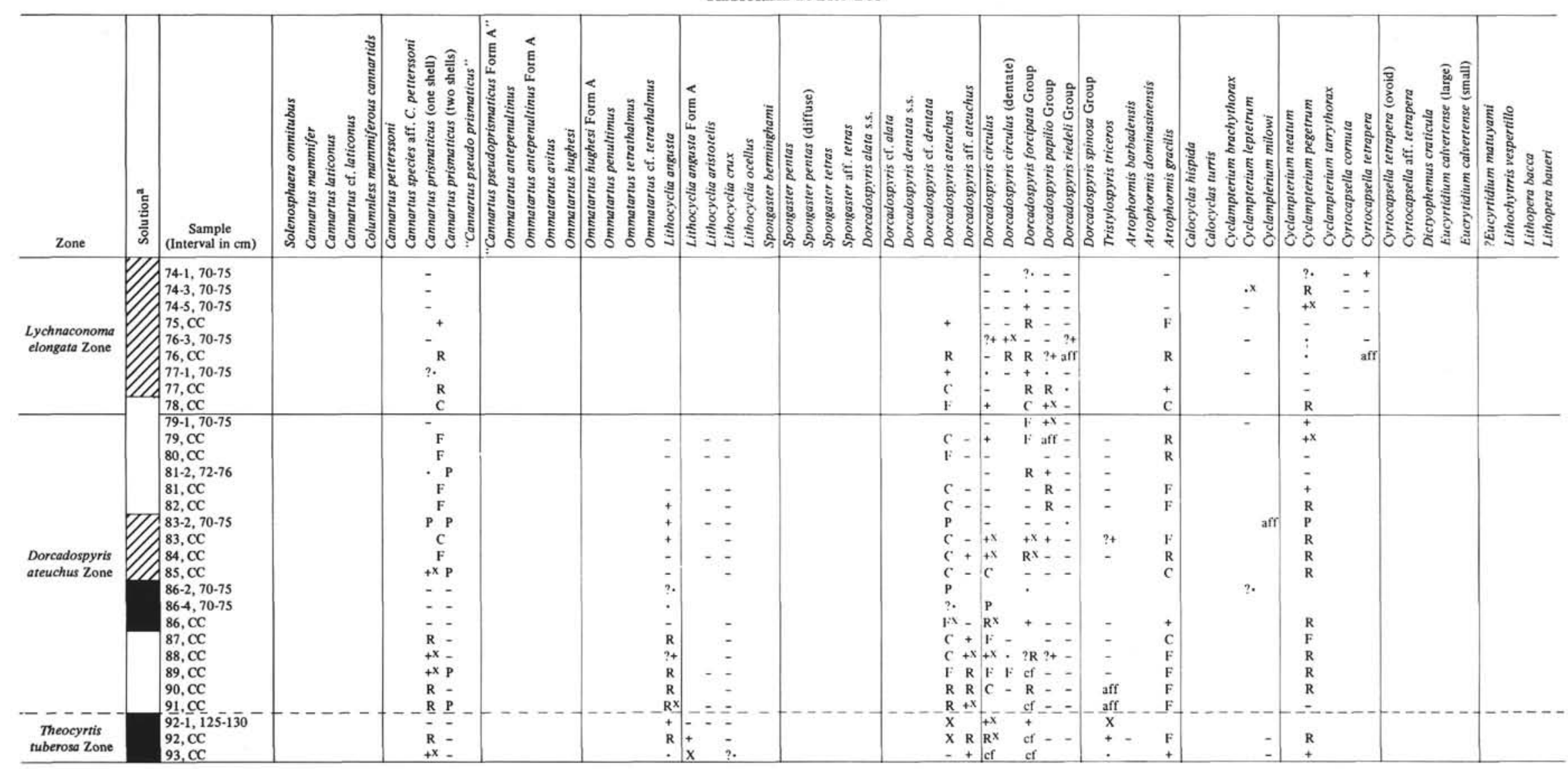




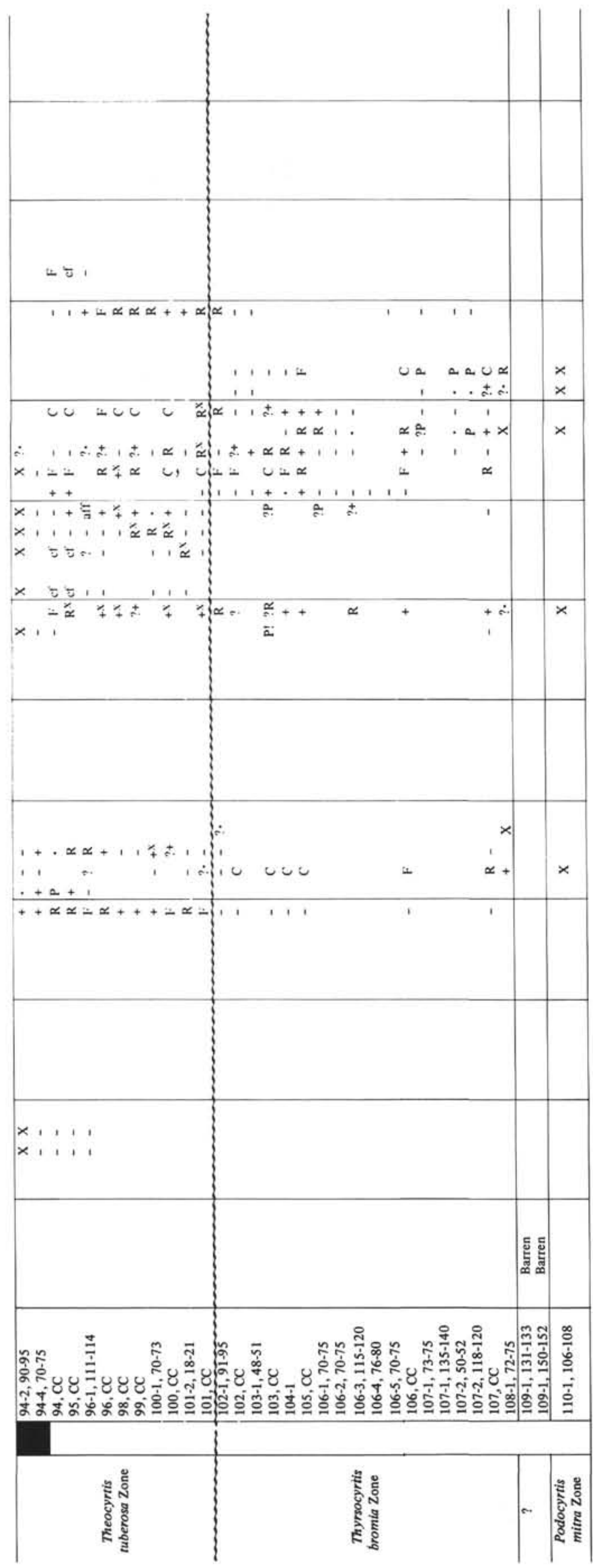

possible that the abundance of this species through its comparatively short range at Site 289 is partly due to concentration by selective solution of the total Radiolaria component of the sediment.

\section{Cannartus bassanii (Carnevale) \\ (Plate 1, Figures 1, 2)}

Sanfilippo et al., 1973, plate 1, fig. 1-3.

During tabulation of Site 289 samples, specimens similar to $C$. bassanii were encountered through a long segment of the hole. The distinction between $C$. bassanii and the Cannartus tubarius-Cannartus violina group was not, however, clear to the writer at that time, and to avoid possible confusion records have been omitted from the published tabulation. The morphologic base of the species is indicated in the events list for Site 289 and the earliest observed specimen is figured (Plate 1). C. bassanii appears to be the earliest cannartid at Site 289 showing an equatorial stricture.

\section{Cannartus laticonus Riedel}

Riedel and Sanfilippo, 1971, plate 1c, fig. 13.

\section{Cannartus ef. laticonus}

Cannartus mammifer (Haeckel)

Riedel and Sanfilippo, 1971, plate 2c, fig. 1-3.

\section{Columnless mammiferous cannartids.}

C. laticonus is considered in this account to be distinguished from $C$. mammifer by the presence of a narrow, unarched clear zone at the bases of the two relatively broad columns. Specimens in which these clear zones are only very weakly developed have been tabulated as $C$. cf. laticonus. Frequently strongly mammiferous coritcal shells are encountered, sometimes in profusion, which totally lack columns, probably due to breakage or solution. Such specimens can be allocated to neither species with certainty and have been separately tabulated as "columnless mammiferous cannartid." At Site 289 the first appearance of such specimens is slightly higher than the apparent morphologic base of C. mammifer and provides a comparatively useful datum.

The evolutionary transition between $C$. mammifer and $C$. laticonus has been taken at the level where specimens definitely allocatable to $C$. laticonus first numerically exceed specimens definitely allocatable to $C$. mammifer. But at Site 289, slightly above this level, there is apparently a short-lived reversion to a $C$. mammifer cominated population. Very little reliance can be placed on this transition as a chronostratigraphic datum.

\section{Cannartus petterssoni Riedel and Sanfilippo}

Riedel and Sanfilippo, 1971, plate 1c, fig. 19.

Differentiation between the earliest morphotypes and late $C$. laticonus morphotypes was found difficult.

\section{Cannartus sp. aff. C. petterssoni}

Riedel and Sanfilippo, 1971, plate 1c, fig. 15

This distinctive morphotype appears to have a very short range at Site 289.

\section{Cannartus prismaticus (Haeckel)}

Riedel and Sanfilippo, 1971, plate 2c, fig. 11-13; plate 4, fig. 5 .

This species shows considerable variation throughout its range, particularly with respect to the strength of development of the medullary shell. Some specimens, perhaps the majority, completely lack a medullary shell prior to the Lithocyclia angusta $\rightarrow C$. prismaticus transition. The single shell form is noted by Goll (1972) and figured by Riedel and Sanfilippo (1971, plate 4, fig. 5). Lithocyclia angusta Form A (see below) appears to constitute the morphologic link between this primitive $C$. prismaticus and typical $L$. angusta. Whether the typical two-shelled, late $C$. prismaticus population develops by reaquisition of the medullary shell, or whether the lineage $L$. angusta-L. angusta Form A-C. prismaticus (one shell) constitutes a separate development is not clear at present. At Site 289 the extinction of the single-shelled form is very tentatively placed slightly higher than the extinction level of typical $L$. angusta. 


\begin{tabular}{|c|c|c|c|c|c|c|c|c|c|c|c|c|c|}
\hline $\begin{array}{l}\text { Lychnocanoma } \\
\text { elongata Zone }\end{array}$ & 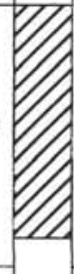 & $\begin{array}{l}74-1,70-75 \\
74-3,70-75 \\
74-5,70-75 \\
75, \mathrm{CC} \\
76-3,70-75 \\
76, \mathrm{CC} \\
77-1,70-75 \\
77, \mathrm{CC} \\
78, \mathrm{CC} \\
\end{array}$ & & $\begin{array}{l}\mathrm{F} \\
\mathrm{F} \\
\mathrm{F} \\
\mathrm{F} \\
\mathrm{P} \\
\mathrm{C} \\
\mathrm{C} \\
\mathrm{C} \\
\mathrm{F}\end{array}$ & & $\begin{array}{l}\overline{-} \\
\mathrm{R} \\
\mathrm{R} \\
- \\
\overline{-} \\
\overline{-} \\
-\end{array}$ & & 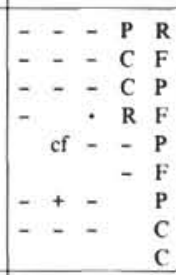 & $\begin{array}{l}\mathrm{x} \\
\mathrm{x} \\
\mathrm{x} \\
\mathrm{x} \\
\mathrm{x} \\
- \\
-\end{array}$ & & \begin{tabular}{|l}
$\mathrm{R}$ \\
$\mathrm{F}$ \\
$\mathrm{R}$ \\
+ \\
$\mathrm{P}$ \\
$\mathrm{R}$ \\
$\mathrm{C}$ \\
$\mathrm{C}$ \\
\end{tabular} & 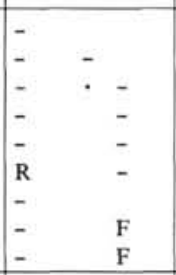 & 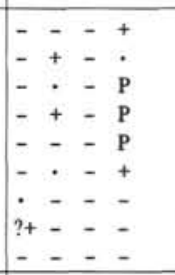 \\
\hline $\begin{array}{l}\text { Dorcadospyris } \\
\text { ateuchus Zone }\end{array}$ & 8 & \begin{tabular}{|l|}
$79-1,70-75$ \\
$79, \mathrm{CC}$ \\
$80, \mathrm{CC}$ \\
$81-2,72-76$ \\
$81, \mathrm{CC}$ \\
$82, \mathrm{CC}$ \\
$83-2,70-75$ \\
$83, \mathrm{CC}$ \\
$84, \mathrm{CC}$ \\
$85, \mathrm{CC}$ \\
$86-2,70-75$ \\
$864,70-75$ \\
$86, \mathrm{CC}$ \\
$87, \mathrm{CC}$ \\
$88, \mathrm{CC}$ \\
$89, \mathrm{CC}$ \\
$90, \mathrm{CC}$ \\
$91, \mathrm{CC}$
\end{tabular} & & $\begin{array}{l}- \\
\overline{-} \\
- \\
+ \\
+ \\
\end{array}$ & & $\begin{array}{l}- \\
- \\
- \\
- \\
- \\
- \\
+ \\
- \\
\vdots \\
\text { P } \\
- \\
-\end{array}$ & & $\begin{array}{l}-\mathrm{c} \\
\mathrm{c} \\
\mathrm{c} \\
\mathrm{P} \\
\mathrm{c} \\
-\end{array}$ & - & 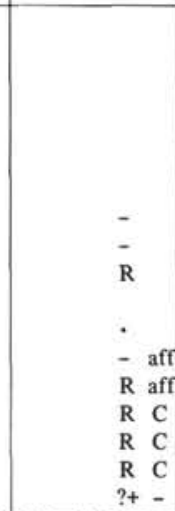 & $\begin{array}{l}\mathrm{C} \\
\mathrm{C} \\
\mathrm{F} \\
\mathrm{C} \\
\mathrm{P} \\
\mathrm{F} \\
\mathrm{R} \\
\mathrm{C} \\
\mathrm{P} \\
\mathrm{F} \\
\mathrm{F} \\
\mathrm{R} \\
-\end{array}$ & \begin{tabular}{|ll}
$\mathrm{F}$ & $\overline{\mathrm{C}}$ \\
+ & $\mathrm{R}$ \\
- & - \\
+ & $\mathrm{R}$ \\
$\overline{\mathrm{P}}$ & $\mathrm{F}$ \\
$\mathrm{R}$ & $\mathrm{C}$ \\
- & $\mathrm{R}$ \\
& $\mathrm{R}-$ \\
& \\
& - \\
& $\mathrm{R}$
\end{tabular} & 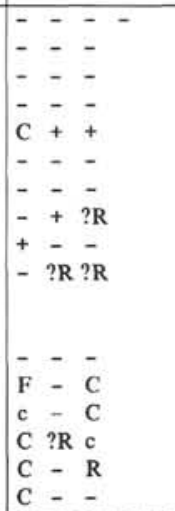 \\
\hline $\begin{array}{c}\text { Theocyrtis } \\
\text { tuberosa Zone }\end{array}$ & & $\begin{array}{l}\frac{91, C C}{92-\overline{1}, 125-130}-- \\
92, C C \\
93, C C \\
94-2,90-95 \\
94-4,70-75 \\
94, C C \\
95, C C \\
96-1,111-114\end{array}$ & & & & $\overline{-}$ & & & & $\begin{array}{l}\mathrm{F}- \\
\mathrm{P} \\
-\end{array}$ & - & $\mathrm{R}=$ & 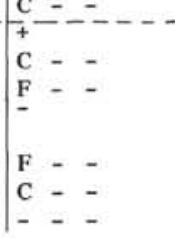 \\
\hline
\end{tabular}




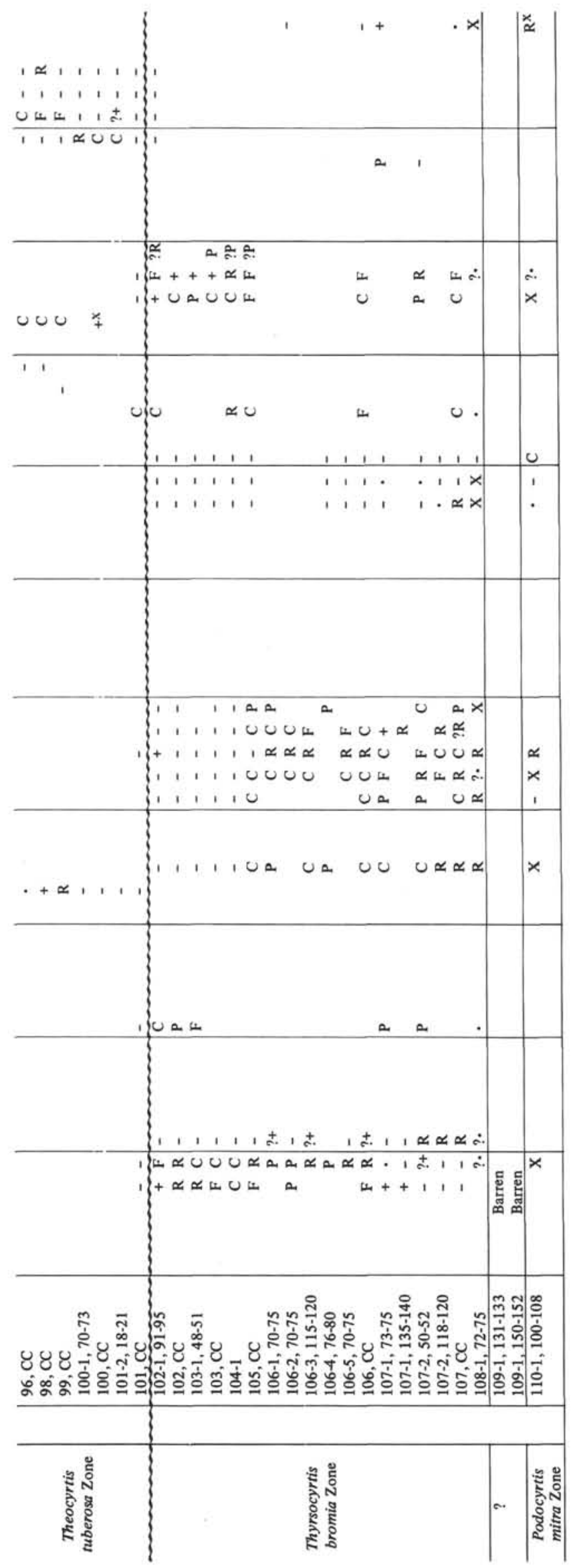

\section{"Cannartus pseudoprismaticus"}

This informal designation is used for smooth or very slightly mammilate specimens, lacking a marked equatorial constriction, superficially similar to $C$. prismaticus but occurring at higher levels. They have been figured by Sanfilippo and Riedel (1974) as "Cannartus sp. cf. C. prismaticus" (plate 1, fig. 1) and "Cannartus sp." (plate 1, fig. 9). The latter, more mammilate form is the earlier at Site 289 and may well have originated from $C$. laticonus stock by loss of clear zones and smoothing of the cortical shell. The former, smoother morphotype is believed to represent an analogous modification within the Ommatartus antepenultimus stock and occurs in association with a form totally lacking columns (Sanfilippo and Riedel, 1974, plate 1, fig. 8; Riedel and Sanfilippo, 1971, plate 10, fig.1), excluded here from " $C$. pseudoprismaticus" and tabulated as "C. pseudoprismaticus Form A."

\section{Cannartus tubarius (Haeckel)}

\section{Cannartus violina (Haeckel)}

The differentiation of these species was found to be so difficult that both have been omitted from the published tabulations. Some morphologic gradation may also exist between $C$. bassanii like and $C$. tubarius like forms.

\section{Lithapium anoectum Riedel and Sanfilippo}

Sanfilippo and Riedel, 1973, plate 24, fig. 6, 7.

\section{Ommatartus antepenultimus Riedel and Sanfilippo}

Riedel and Sanfilippo, 1971, plate 1C, fig. 11.

This species is considered in this account to be distinguished from $C$. laticonus by the presence of distinct caps with rounded tops and convex walls. Early specimens are completely gradational with $C$. laticonus and the evolutionary transition from $C$. laticonus to $O$. antepenultimus is nebulous. Later $O$. antepenultimus populations show considerable variation with respect to the shape of the cortical shell and cap development, the later form of "C. pseudoprismaticus" probably being an extreme variant.

\section{Ommatartus antepenultimus Form $\mathbf{A}$}

A distinctive morphotype in which a single extra chamber is developed in both columns adjacent to the tops of the main caps. The range indicated for this form at Site 289 is provisional.

\section{Ommatartus avitus Sanfilippo and Riedel}

Sanfilippo and Riedel, 1974, plate 1, fig. 10.

The name has been used in a broad sense for specimens with welldeveloped, rounded caps, lacking any trace of columns. Solution of the columns of $O$. antepenultimus and $O$. penultimus may well be responsible for some of the records, but the transition from an " $O$. avitus" dominated population to an Ommatartus tetrathalmus dominated population is reasonably convincing at Site 289 .

\section{Ommatartus hughesi (Campbell and Clark)}

Riedel and Sanfilippo, 1971, plate 1c, fig. 17, 18.

The earliest specimens allocated to $O$. hughesi in this account possess the cap at the end of the cortical shell, plus at least two further distinct chambers. Although $O$. hughesi is conventionally considered here to arise from $C$. petterssoni, the great variability of $O$. hughes $i$ like forms strongly suggests that more than one lineage is involved and that the trend towards forms with multiple chambers may have developed in both $C$. petterssoni and $O$. antepenultimus stocks.

\section{Ommatartus hughesi Form A}

(Plate 1, Figures 3-6)

A distinctive morphotype with very short range at Site 289 . The appearance of the cortical and medullary shells is virtually identical with that of $C$. petterssoni, and incomplete specimens could be confused with this species. The range of $O$. hughesi Form A is apparently higher than and separated from that of $C$. petterssoni. 


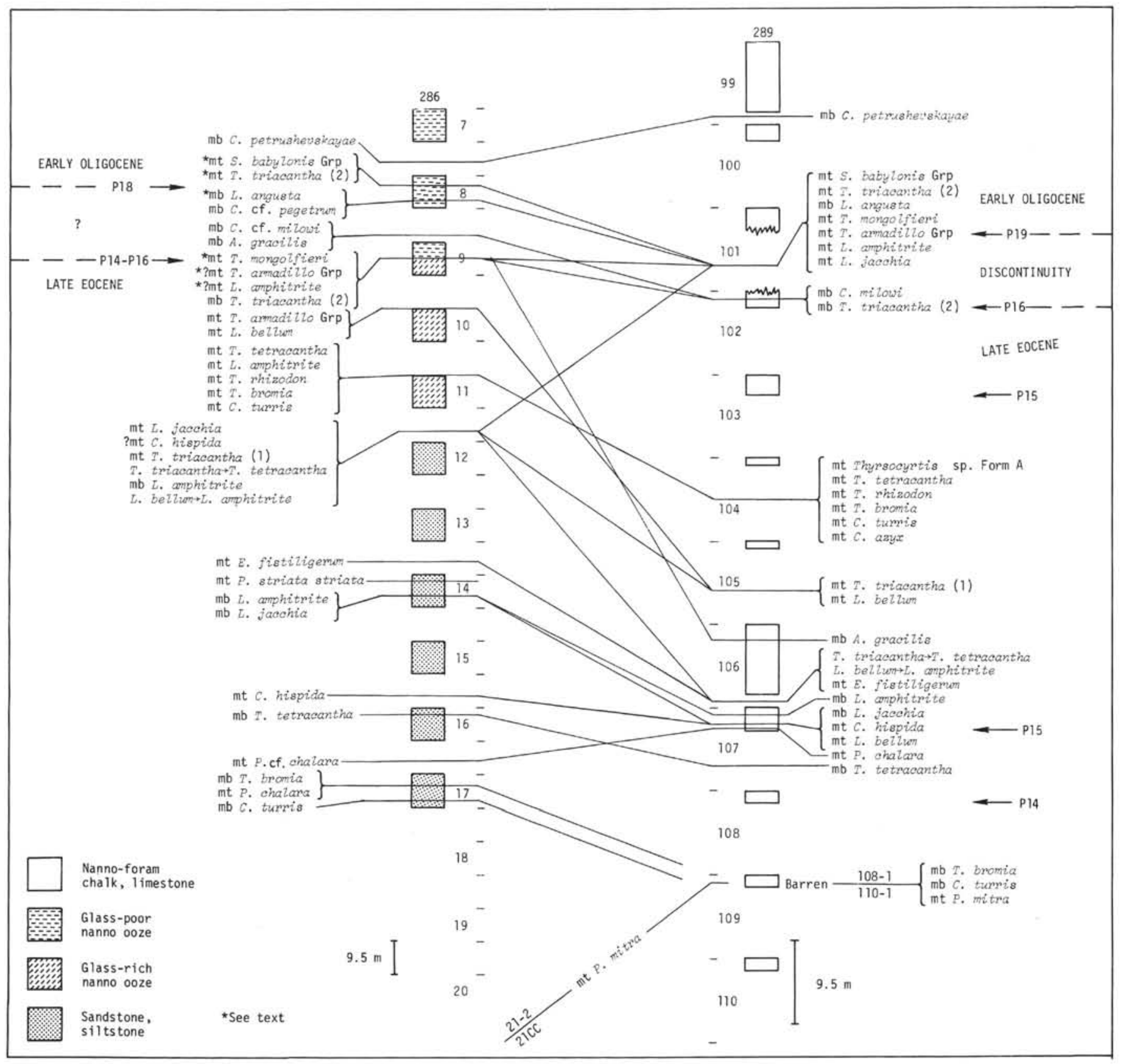

Figure 3. Eocene-earliest Oligocene correlation of Sites 286 and 289.

\section{Ommartartus penultimus (Riedel)}

Riedel, 1957, plate 1, fig. 1.

Differentiation of this species morphotype from the later $O$. antepenultimus morphotypes is virtually impossible, in the writer's experience, at levels where, according to earlier accounts, the evolutionary transition from $O$. antepenultimus to $O$. penultimus should occur. The difficulty has probably led to rather widely differing interpretations of the $O$. penultimus Zone in previous reports. In this account the name " $O$. penultimus" has been restricted to specimens in which the caps are distinctly inflated and in which at least one cap is roughly as large or larger than half the cortical shell.

\section{Ommatartus tetrathalmus (Haeckel)}

Riedel and Sanfilippo, 1971, plate Ic, figs. 5, 6.

This species is highly distinctive in the later part of its range, but in the earlier part is completely gradational with typical $O$. avitus. " $O$. tetrathalmus" has been used in this account for specimens in which the caps tend to have flattened sides and a pointed termination and in which the conical cap is attached to the cortical shell by fairly welldeveloped beams. True columns are lacking. Specimens with either rounded cap and well-developed beams or with slightly conical caps and poorly developed beams are tabulated as $O$. cf. tetrathalmus, but the distinction is indefinite and the criteria have probably not been applied consistently. Hays et al. (1969) have employed a rather different definition of $O$. tetrathalmus and have, therefore, probably placed the extinction of $O$. penultimus somewhat lower than the position very tentatively suggested at Site 289 .

Periphaena tripyramis triangula (Sutton)

Sanfilippo and Riedel, 1973, plate 9, fig. 10, 11.

Periphaena tripyramis tripyramis (Haeckel)

Sanfilippo and Riedel, 1973, plate 9, fig. 7-9 


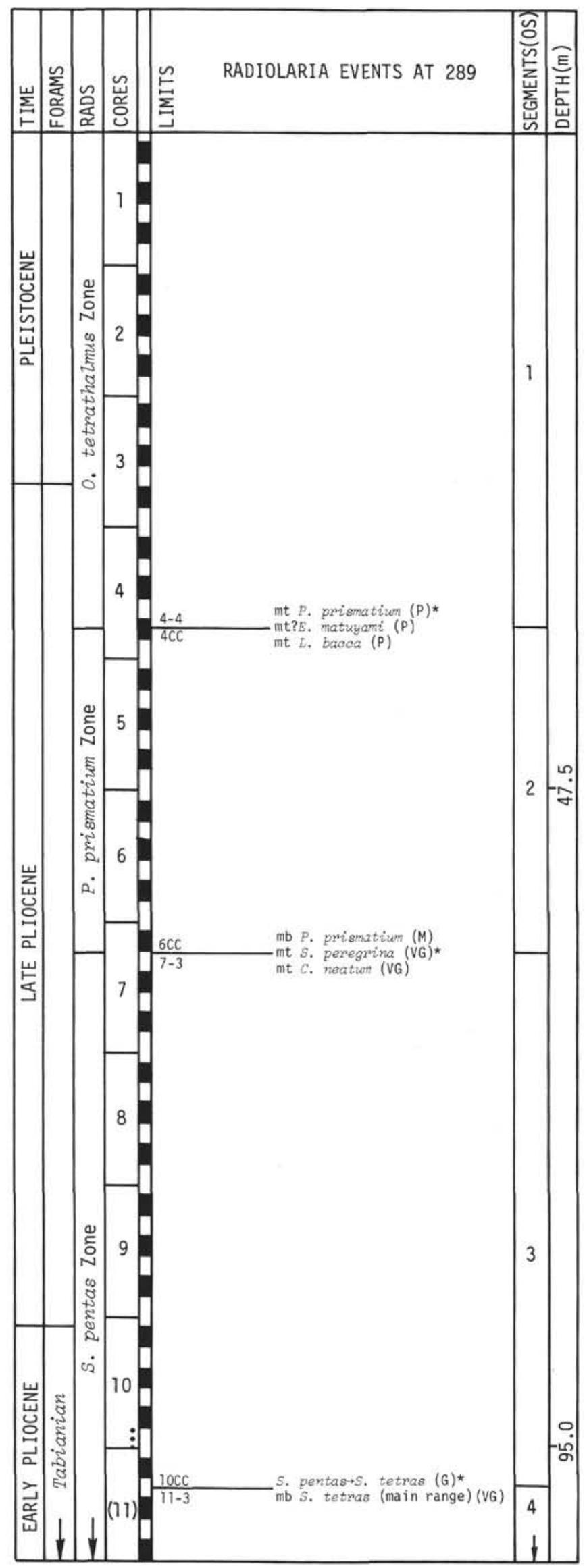

Figure 4. Radiolaria events at Site 289.

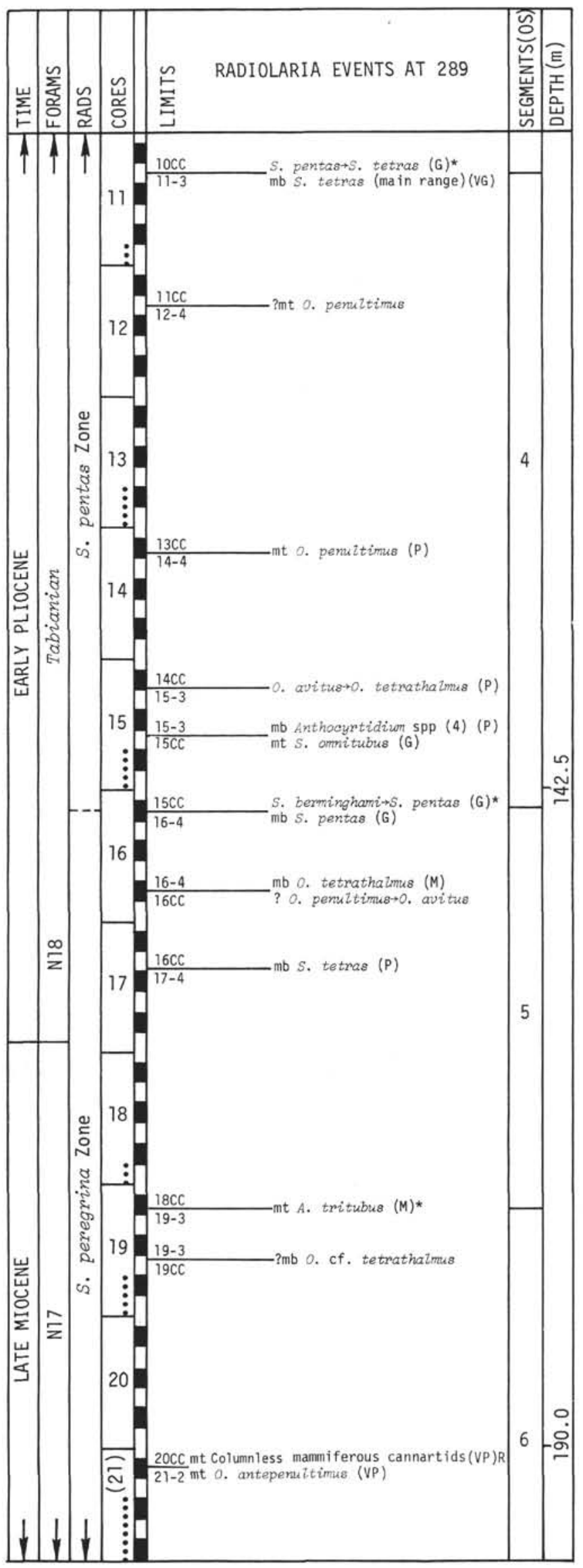

Figure 4. (Continued). 


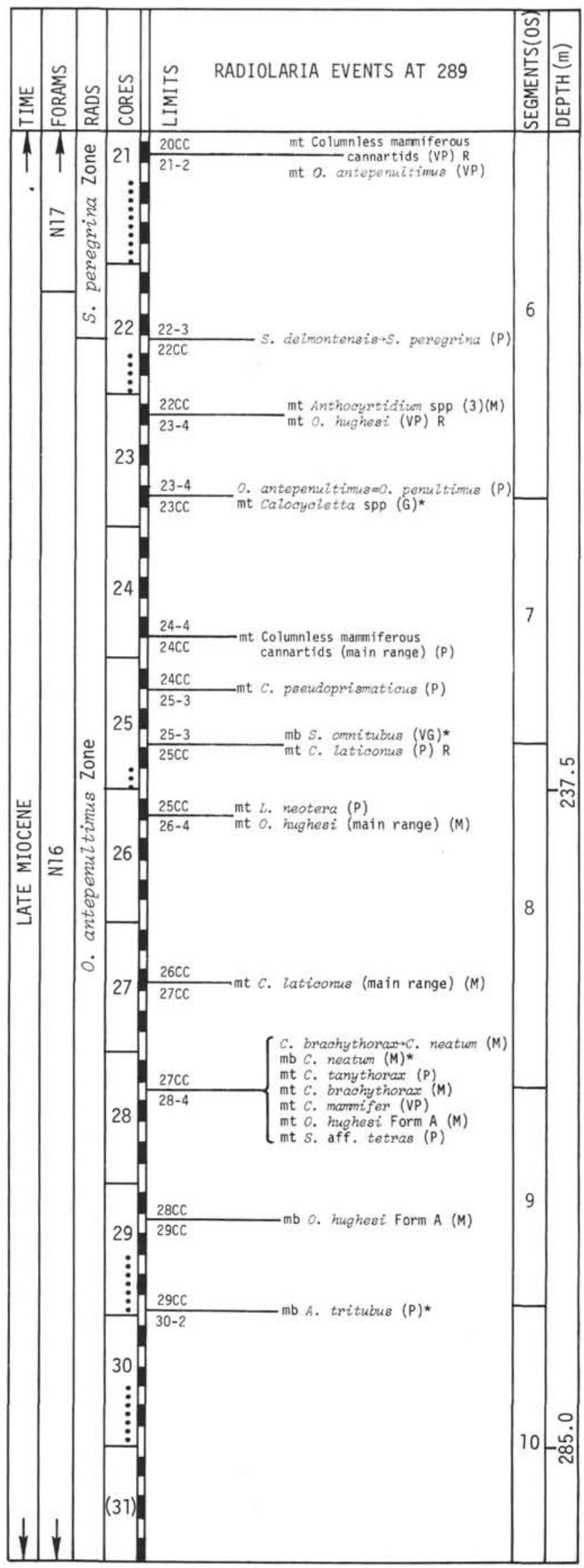

Figure 4. (Continued).

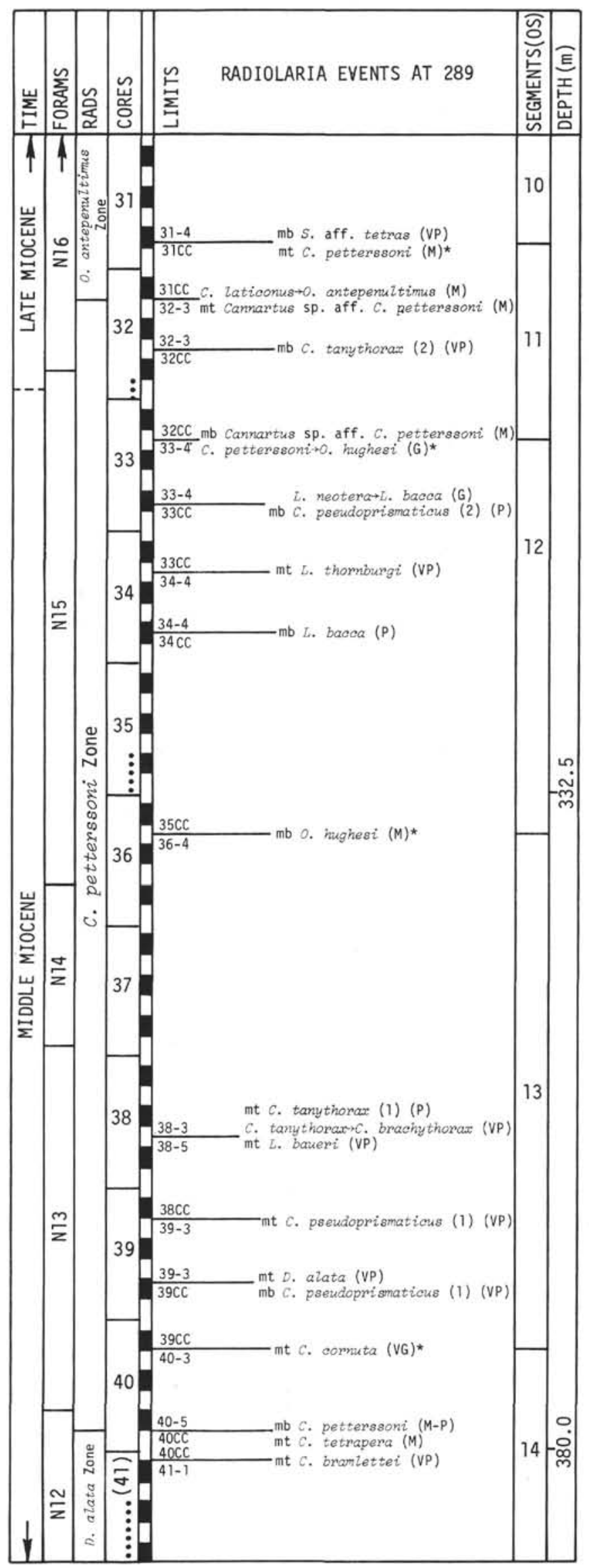

Figure 4. (Continued). 
CENOZOIC RADIOLARIA BIOSTRATIGRAPHY

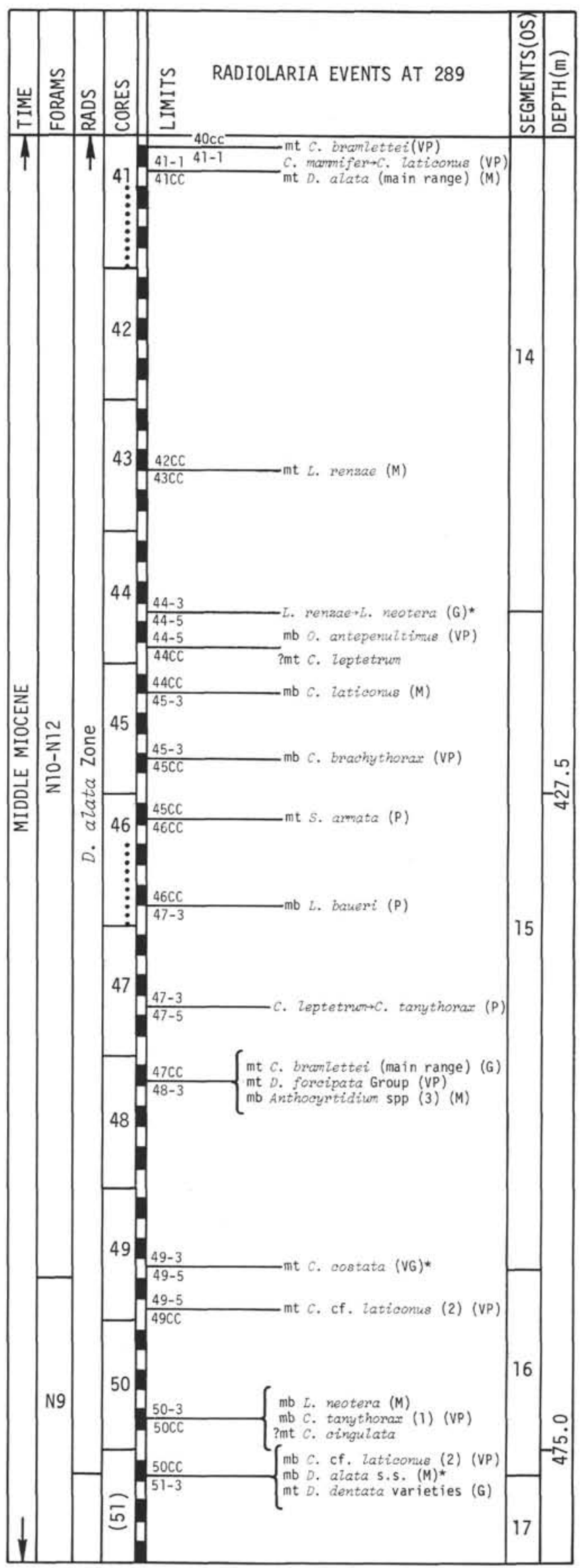

Figure 4. (Continued).

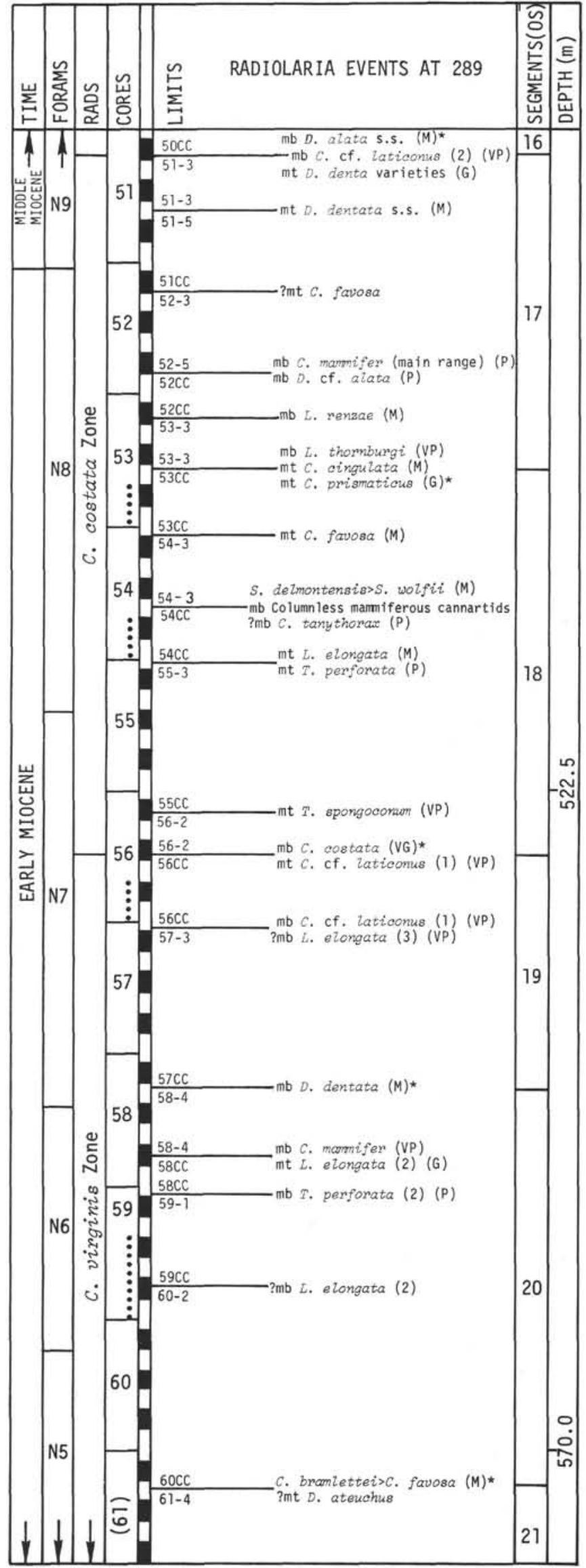

Figure 4. (Continued). 


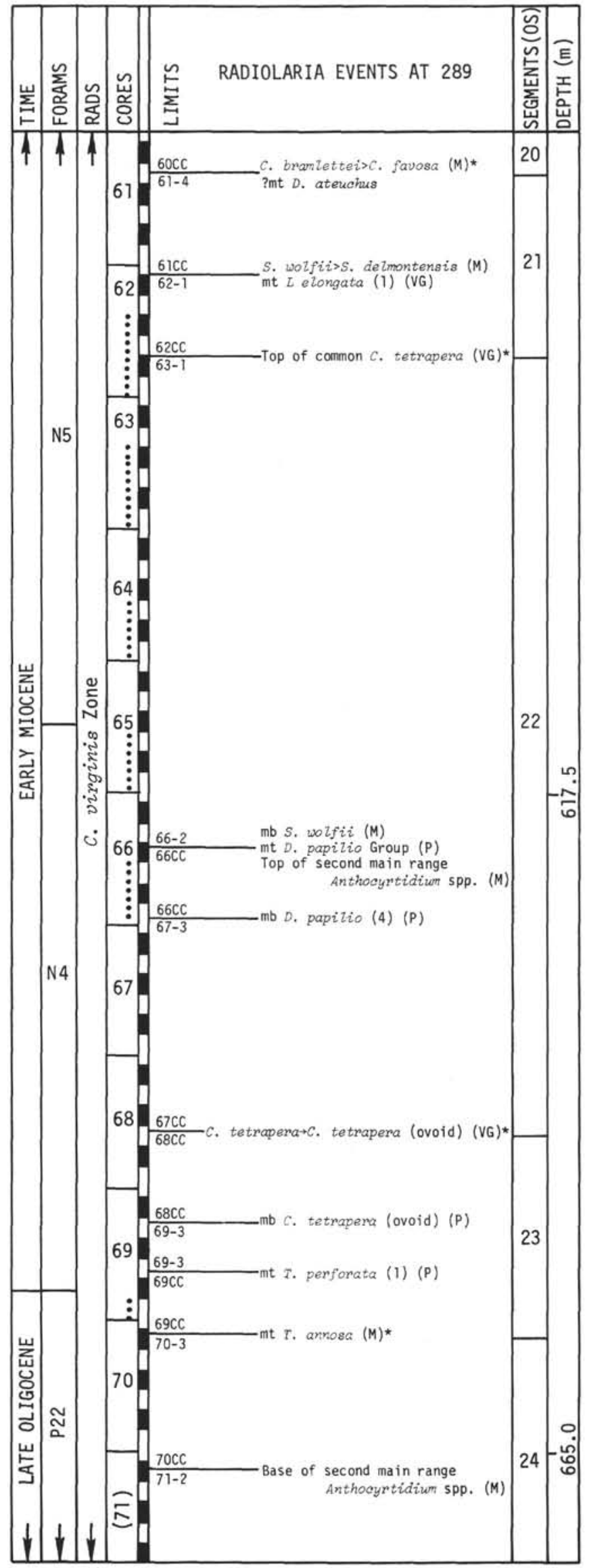

Figure 4. (Continued).

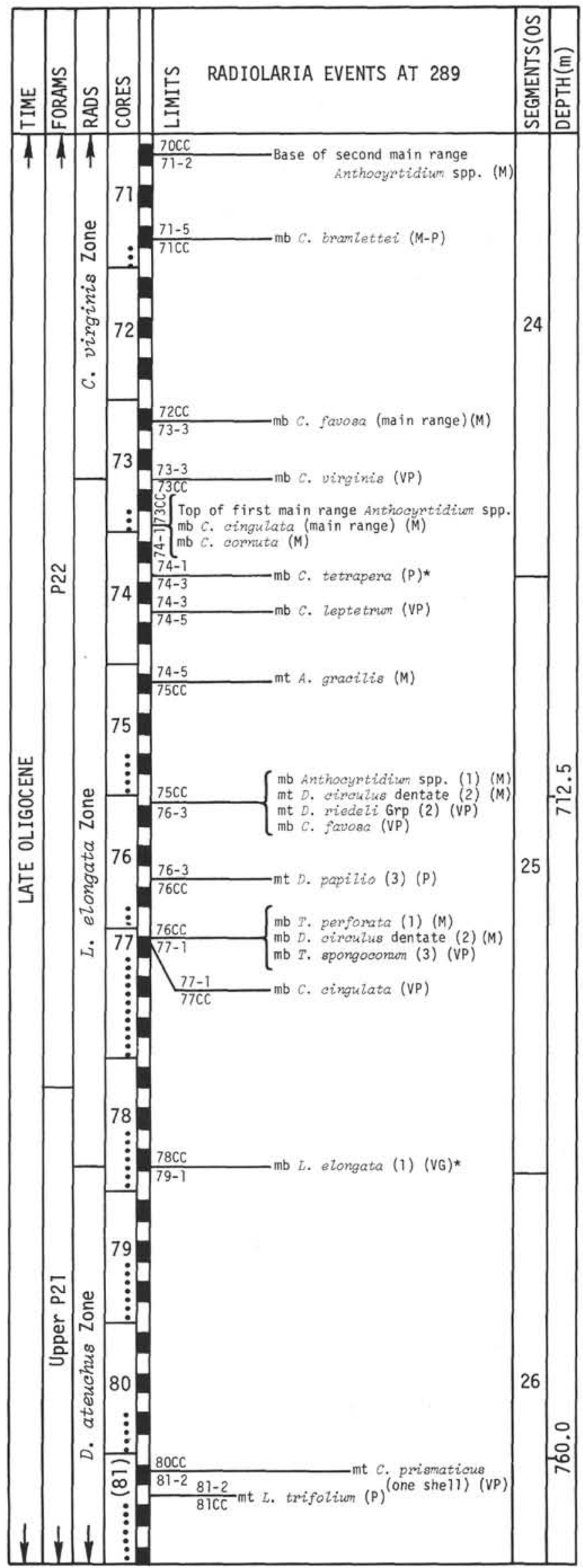

Figure 4. (Continued). 
CENOZOIC RADIOLARIA BIOSTRATIGRAPHY

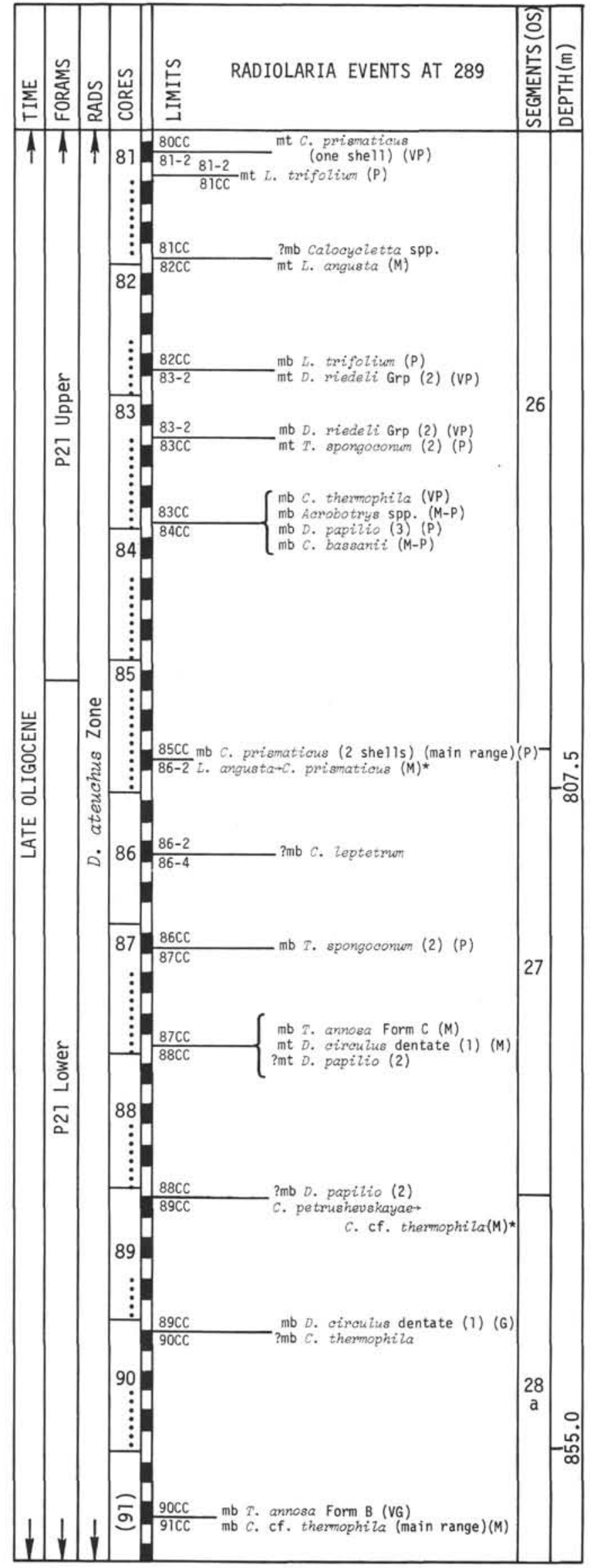

Figure 4. (Continued).

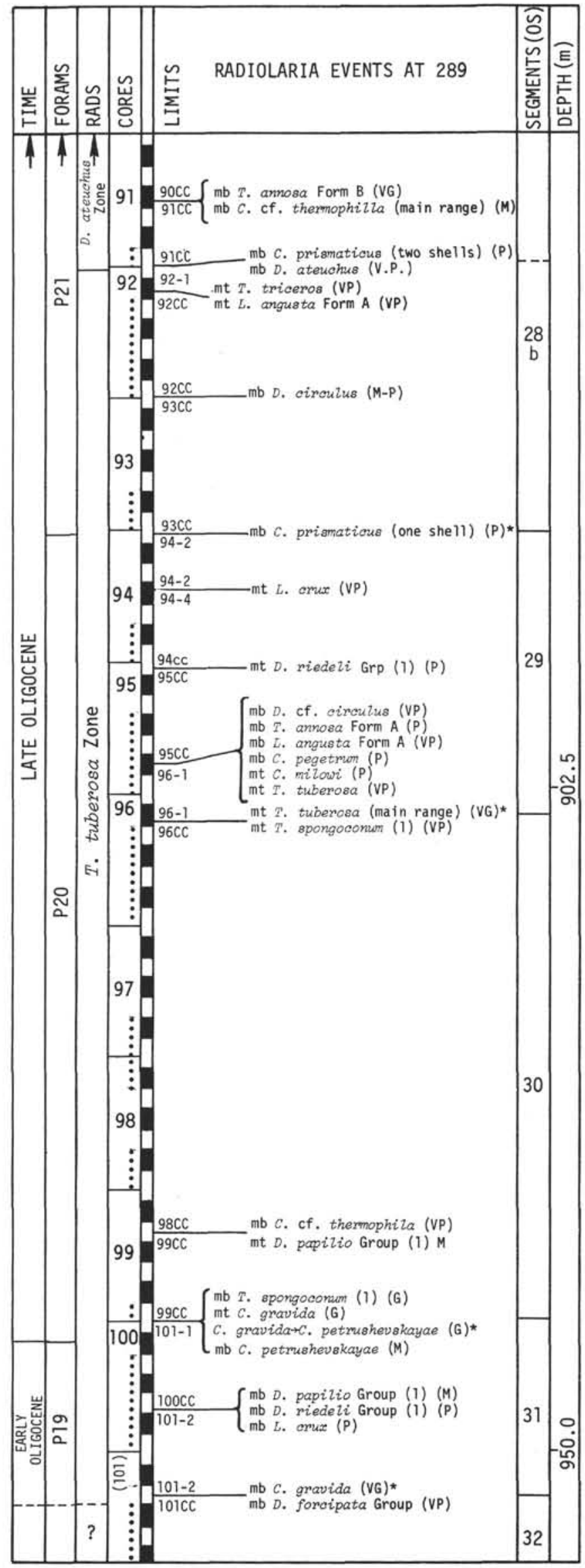

Figure 4. (Continued). 


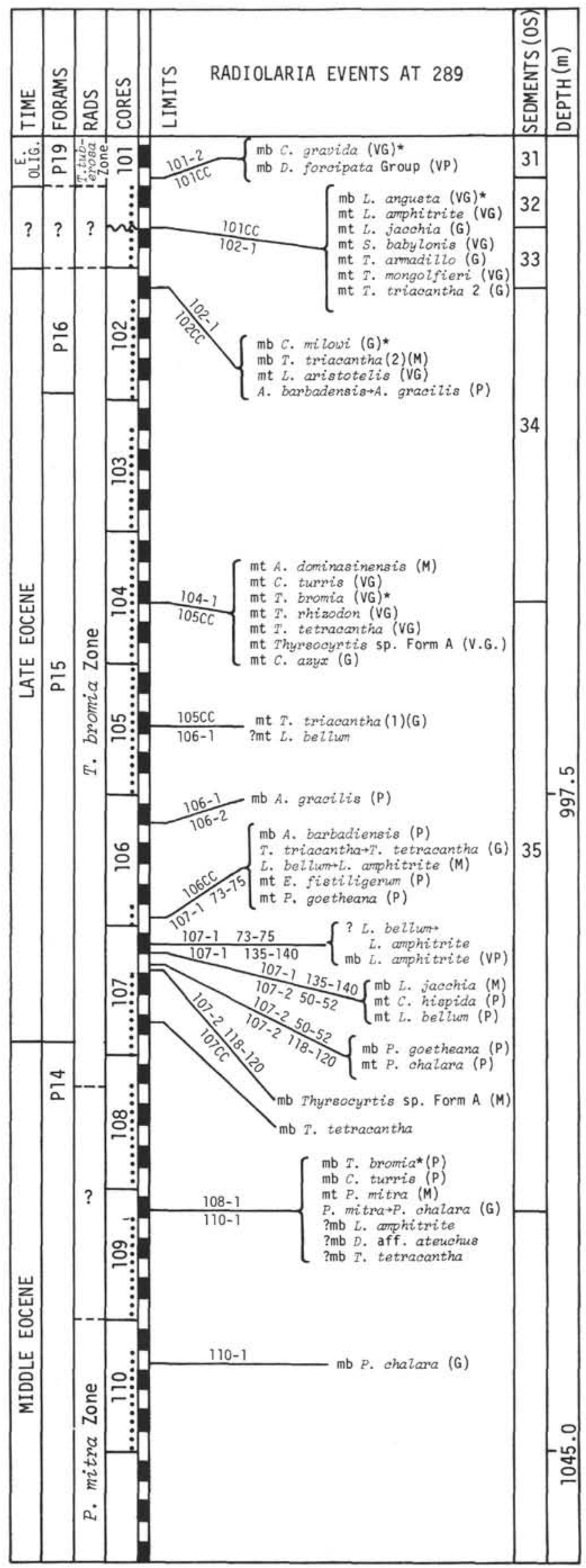

Lithocyclia angusta (Riedel)

Riedel and Sanfilippo, 1971, plate 3A, fig. 1-3.

\section{Lithocyclia angusta Form A}

(Plate 1, Figures 7-8)

A rare, highly distinctive morphotype of very short range at Site 289 , appearing slightly before and disappearing slightly after the first appearance of $C$. prismaticus. The spherical cortical shell, apparently lacking medullary shell, bears three weak spongy $L$. angusta like spines, and probably gave rise to $C$. prismaticus (single shell) by loss of one spine and relocation of the remaining two spines in polar positions. (See also above under $C$. prismaticus.)

\section{Lithocyclia aristotelis (Ehrenberg) Group}

Riedel and Sanfilippo, 1971, plate 3A, fig. 4, 5.

\section{Lithocyclia crux Moore}

Riedel and Sanfilippo, 1971, plate 3A, fig. 2.

\section{Lithocyclia ocellus Ehrenberg Group}

Riedel and Sanfilippo, 1971, plate 3A, fig. 6

\section{Spongaster berminghami Campbell and Clark}

Riedel and Sanfilippo, 1971, plate 1D, fig. 8-10

\section{Spongaster pentas Riedel and Sanfilippo}

Riedel and Sanfilippo, 1971, plate 1D, fig. 5, 7

The name " $S$. pentas" has been restricted to specimens of essentially circular form with five or more well-defined dark areas. The first appearance of such a form is clearly detectable at Site 289. Specimens often smaller, with a diffuse, essentially undivided dark area, similar to Riedel and Sanfilippo, 1971, plate 1D, fig. 6 are tabulated as " $S$. pentas (diffuse)."

\section{Spongaster tetras Ehrenberg}

Riedel and Sanfilippo, 1971, plate 1D, fig. 2-4.

\section{Spongaster aff. tetras}

A more robust form of apparently very short range in the $O$. antepenultimus Zone, similar to Riedel and Sanfilippo, 1971, plate 5, fig. 1, but apparently younger.

\section{Dorcadospyris alata (Riedel)}

Riedel and Sanfilippo, 1971, plate 2D, fig. 1

\section{Dorcadospyris dentata (Haeckel)}

Riedel and Sanfilippo, 1971, plate 2D, fig. 2, 3 .

Gradation in external morphology within a very short segment at Site 289 strongly suggests that typical $D$. dentata gave rise to typical $D$. alata, though Goll (1972) has demonstrated significant differences between the collar pore patterns of these species. The evolutionary transition $D$. dentata $\rightarrow D$. alata is accepted in this account.

" $D$. dentata s.s." is used for specimens with and without the cephalic horn. "D. alata s.s." is used for specimens lacking the cephalic horn and having two very extensive feet of continuous curvature with dentation variable but usually weak. Specimens with extension, dentation, and curvature of the feet of intermediate degree are tabulated either as "D. cf. dentata" or D. cf. alata." These intermediate morphotypes are found through only a very small thickness even at Site 289 , where accumulation rate was probably abnormally high, and they are unlikely to produce serious confusion in the placing of the $D$. dentata $\rightarrow D$. alata transition in most sections. At the top of its range at Site 289 D. alata is quite excessively scarce and the true extinction of the species is most unlikely to be determined consistently from section to section. Reduction in cephalis size of $D$. alata appears to be progressive throughout its range at Site 289 and could be a useful indicator of stratigraphic position. At Site 288, upward reworking of fossils is clearly detectable by virtue of the mixing of $D$. alata specimens of differing cephalis size.

Figure 4. (Continued). 


\section{Dorcadospyris ateuchus (Ehrenberg)}

Riedel and Sanfilippo, 1971, plate 2D, fig. 6; plate 3A, fig. 9, 10.

The name is used for specimens possessing only two major feet of equal thickness and length, both showing a slight to marked outward curvature of the terminations. Scarcity and breakage of specimens renders the upper and lower limits of the range of this species uncertain at Site 289 .

\section{Dorcadospyris aff. ateuchus}

This designation is used in tabulations for specimens not perfectly conforming with the diagnosis of $D$. ateuchus given above, usually possessing a third, weak foot of circular cross-section and/or lacking the symmetry of $D$. ateuchus.

\section{Dorcadospyris circulus (Haeckel)}

Moore, 1971, plate 8, fig. 3-5.

The name is used for a variable group of specimens in which only two major feet are present, lacking dentation, and curving continuously inward to fuse in the form of a more or less perfectly circular loop. The group is probably polyphyletic and in need of detailed revision.

\section{Dorcadospyris circulus (dentate)}

(Plate 1, Figures 9-11)

This designation is used for specimens generally agreeing with $D$. circulus as defined above, with or without a cephalic horn, but also bearing teeth of variable strength on the outer margins of the feet. This form occurs through two thin segments at Site 289.

\section{Dorcadospyris forcipata (Haeckel) Group}

Riedel and Sanfilippo, 1971, plate 2C, fig. 29-23; plate 3A, fig. 8.

This name has been used very broadly to cover a much wider range of morphotypes than figured by Riedel and Sanfilippo (1971). Forms with only two pendant, essentially incurving, unfusing feet, with or without cephalic horn, have been included. Forms previously allocated to Dorcadospyris simplex and Dorcadospyris praeforcipata are probably included in the present writer's definition, but if seems unlikely that names presently available are adequate to completely encompass the variation encountered in the present work. Without revision this group seems to be of little practical value in chronostratigraphy.

The following three dorcadospyrid taxa raise problems due to their general scarcity, great variability, and apparently discontinuous ranges. All, however, are of clear stratigraphic utility and a more detailed account is in preparation based upon Site 289 material.

\section{Dorcadospyris papilio (Riedel) Group}

Riedel, 1959, plate 2, fig. 1, 2 .

This designation has been used in tabulations for specimens which agree with Dorcadospyris papilio as originally defined in having two and only two primary feet "initially divergent at approximately $180^{\circ}$ or more" (Riedel, 1959, p. 294). Moore (1971) described as a new species Dorcadospyris pseudopapilio with primary feet "usually strongly divergent (equal to or greater than $180^{\circ}$ )," but showing some examples with less divergent feet. This species was distinguished from $D$. papilio by the possession of two, centrally positioned and opposed serrate, tabular feet. The range of $D$. pseudopapilio as indicated by Moore (1971) is entirely earlier than and separated from that of $D$. papilio.

At Site 289 forms allocatable to either D. papilio or D. pseudopapilio were first encountered in the low $T$, tuberosa Zone, Core 289-100. Some specimens are identical with Moore's figured D. pseudopapilio, but others, with much more extreme flexure of the primary feet, appear to lack secondary feet and can only be assigned to $D$. papilio. Two distinct forms may be present. Specimens generally agreeing with Dorcadospyris papilio Riedel vary considerably from horizon to horizon, particularly in the number and form of the secondary feet. More than one lineage almost certainly exists.

\section{Dorcadospyris riedeli Moore Group}

Moore, 1971, plate 9, fig. 1-3.

Specimens in which at least two strong arching feet appear to arise from the shell have been tabulated under this name. The distinction between $D$. riedeli and Dorcadospyris quadripes Moore seems not always to be clear, however (see Moore, 1971, plate 7, fig. 4).

\section{Dorcadospyris spinosa Moore Group}

Moore, 1971, plate 7, fig. 1, 2.

Riedel and Sanfilippo, in press, plate 10, fig. 6

Riedel and Sanfilippo, 1973, plate 2, fig. 2.

Figures cited above reveal considerable breadth in the interpretation of $D$. spinosa. In this account "D. spinosa Group" has been used for dorcadospyrids with more than two dentate feet. At Site 289 a form similar to Riedel and Sanfilippo (in press) plate 10, fig. 6, is confined to $T$. bromia Zone, OS.35-34. Specimens from the T. tuberosa Zone appear to differ in having only two (joined), major spinose feet, the remaining (unjoined) feet being spinose but weak.

Tristylosyris triceros (Ehrenberg)

Riedel and Sanfilippo, 1971, plate 3A, fig. 11, 12.

Artophormis barbadensis (Ehrenberg)

Riedel and Sanfilippo, 1971, plate 3B, fig. 8, 9.

Artophormis dominasinensis (Ehrenberg)

Riedel and Sanfilippo, 1971, plate 6 , fig. 6

Artophormis gracilis Riedel

Riedel and Sanfilippo, 1971, plate 3B, fig. 5-7

Calocyclas hispida (Ehrenberg)

Riedel and Sanfilippo, 1971, plate 3B, fig. 10, 11

Calocyclas turris (Ehrenberg)

Riedel and Sanfilippo, 1970, plate 13, fig. 3, 4.

C. turris is clearly distinguished from C. hispida by the presence of a true perforate abdomen. In the upper Podocyrtis mitra Zone at Site 286 a few Calocyclas specimens show the incipient development of such an abdomen in the form of a single, usually incomplete, ring of anastomoses between the strap-like feet, developed close to the thorax periphery. "C. turris" has been restricted to specimens in which at least two such complete rings are present.

\section{Calocycloma ampulla (Ehrenberg)}

Foreman, 1973, plate 1, fig. 1-5; plate 9, fig. 20.

Cyclampterium brachythorax Sanfilippo and Riedel

Sanfilippo and Riedel, 1970, plate 2, fig. 15, 16.

Cyclampterium leptetrum Sanfilippo and Riedel

Riedel and Sanfilippo, 1971, plate 2D, fig. 9-12.

\section{Cyclampterium milowi Riedel and Sanfilippo}

Riedel and Sanfilippo, 1971, plate 3B, fig. 3.

This species has been interpreted in the original sense of Riedel and Sanfilippo (1971). Only specimens with relatively long abdomen and perforate feet have been admitted, so that the upper limit of this species as shown at Site 289 , will probably differ from the position established by workers using the later concept of C. milowi (Sanfilippo et al., 1973).

At Site 286 the earliest Cyclampterium specimens differ somewhat from forms seen at Site 289, and no typical C. milowi (in the sense of this account) seem to be present.

\section{Cyclampterium neatum Sanfilippo and Riedel}

Sanfilippo and Riedel, 1970, plate 2, fig. 17, 18.

At Site 289 this distinctive species shows a most convincing extinction coincident or nearly so with the extinction of Stichocorys peregrina. A single higher spot occurrence in the Pleistocene is considered to be the result of reworking. At other sites, however, the species seems to have a considerably higher continuous range (Sanfilippo and Riedel, 1974) and has been reported in modern plankton (W.R. Riedel, personal communication).

\section{Cyclampterium pegetrum Sanfilippo and Riedel}

Riedel and Sanfilippo, 1971, plate 20, fig. 13, 14; plate 3B, fig. 1, 2.

This species shows considerable morphologic change throughout its range at Site 289 and certain variants may be characteristic of comparatively thin segments in the hole. A morphotype with very short, 
strong, closed abdomen, probably identical with Sanfilippo et al., 1973, plate 4, fig. 16, 17, is particularly distinctive and probably short ranging. As interpreted in this account, the earliest $C$. pegetrum specimens tend to have somewhat weaker abdomen bars than later forms. Early forms at Site 286 with weak abdomen bars have comparatively long, incurving, needle-like feet which suggest that they may have arisen from the Thyrsocyrtis triacantha-Thyrsocyrtis tetracantha Group. At both Sites 286 and 289 the earliest appearance of Cyclampterium specimens is associated with a brief reappearance of rare $T$. triacantha.

\section{Cyclampterium tanythorax Sanfilippo and Riedel}

Sanfilippo and Riedel, 1970, plate 2, fig. 13, 14.

This form is fairly clearly distinguishable from the later $C$. brachythorax by its inflated, undepressed thorax. At Site 289, however, some Cyclampterium specimens revert to the $C$. tanythorax shape shortly before the evolutionary transition to $C$. neatum.

Cyrtocapsella cornuta (Haeckel) amended herein

(Plate 2, Figures 1-3, 5-7, 8, 10, 16)

Cyrtocapsella tetrapera (Haeckel) amended herein

(Plate 2, Figures 9, 13-15)

\section{Cyrtocapsella tetrapera (ovoid)}

(Plate 2, Figures 11, 12)

\section{Cyrtocapsella aff. tetrapera}

(Plate 2, Figure 4)

The definitive accounts of the species $C$. cornuta and $C$. tetrapera as understood by modern workers are those of Sanfilippo and Riedel (1970). In this report modifications to the Sanfilippo and Riedel concepts of these two species have been introduced in light of evidence regarding the evolution of Cyrtocapsella spp. at Site 289, and in an attempt to provide more readily recognizable datum levels within the evolutionary record of the genus.

Cyrtocapsella, in the widest sense, is a theoperid with the third or fourth segment cap-shaped and the aperture of this segment more or less constricted. If further segments exist they are thin-walled, narrower than the constricted segment, and their presence is not associated with any reduction in the stricture of the aperture of this preceding segment. So defined, Cyrtocapsella clearly arises from an earlier group of elongate, multisegmented theoperids with essentially unrestricted segment apertures, generally allocated to Eucyrtidium (Plate 2).

Sanfilippo and Riedel (1970) distinguished C. cornuta from $C$. tetrapera by the break in contour which exists in the former species between thorax and abdomen, but defined both as having very restricted apertures "about twice as wide as a pore." In practice, determination of aperture size is difficult and constriction of the aperture probably increases in successively younger populations. It is unlikely, given a series of closely successive samples, that two observers would place the morphotypic bases of these species, so defined, at the same levels. Nor is the shape distinction between "tetraparoid" and "cornutoid" specimens clear at many horizons.

At Site 289 a much more readily identifiable level is that at which variable populations of multisegmented Eucyrtidium species are rather abruptly replaced by populations dominated by four-segmented theoperids (Plate 2). These first four segmented forms with hemispheric fourth segments have apertures considerably wider than two pore diameters, but it seems useful to distinguish them as " $\mathrm{Cyr}$ tocapsella species." At Site 289 the morphologic base of Cyrtocapsella species, so defined, is 10 meters below the first appearance of Calocycletta specimens sufficiently well preserved as to be identifiable as Calocycletta virginis. The Cyrtocapsella datum may, therefore, be preferable to the $C$. virginis datum as a base for the $C$. virginis Zone (see below under $C$. virginis).

The next important Cyrtocapsella datum at Site 289 is the appearance of $C$. tetrapera in which the outline is virtually completely smooth. This form is referred to as $C$. tetrapera (ovoid). Almost immediately it virtually totally replaces the earlier form. A third useful datum is the level at which C. tetrapera declines drastically in numbers relative to $C$. cornuta-recorded in the 289 events list as "Top of common $C$. tetrapera." Above this level $C$. cornuta develops its most distinctive size and shape, thoug frequently specimens may have a "tetraparoid" appearance due to thickening of the thoracic wall. Such specimens are tabulated as " $C$. aff. tetrapera." "True" $C$. tetrapera, both the ovoid form and a much smaller morphotype of irregular outline, do reappear in considerable numbers at some of these higher levels, but the associated species distinguish these late occurrences from occurrences within the main, lower range of $C$. tetrapera.

\section{Eucyrtidium calvertense Martin}

Kling, 1973, plate 4, fig. 16, 18, 19; plate 11, fig. 1-5.

\section{Eucyrtidium matuyami Hays}

Kling, 1973, plate 4, fig. 17.

Those two species were searched for only in the uppermost seven cores of Site 289. E. calvertense seems to be represented by two forms of distinctly different size, the smaller of which persists to the top of the hole. E. matuyami was not definitely identified, but a few specimens tabulated as? E. matuyami coexist with the larger form of $E$. calvertense.

\section{Dictyophimus craticula Ehrenberg}

Sanfilippo and Riedel, 1973, plate 19, fig. 1.

Eusyringium fistiligerum (Ehrenberg)

Riedel and Sanfilippo, 1971, plate 3B, fig. 14.

\section{Lithochytris vespertillio}

Riedel and Sanfilippo (in press), plate 7, fig. 15.

\section{Lithopera bacca Ehrenberg}

Riedel and Sanfilippo, 1971, plate 1F, fig. 10-13.

\section{Lithopera baueri Sanfilippo and Riedel}

Sanfilippo and Riedel, 1970, plate 2, fig. 4-6.

Lithopera neotera Sanfilippo and Riedel

Sanfilippo and Riedel, 1970, plate 1, fig. 24-26.

Lithopera renzae Sanfilippo and Riedel

Sanfilippo and Riedel, 1970, plate 1, fig. 21-23, 27.

Lithopera thornburgi Sanfilippo and Riedel

Sanfilippo and Riedel, 1970, plate 2, fig. 1, 2.

\section{Lophocyrtis jacchia (Ehrenberg)}

Riedel and Sanfilippo, 1971, plate 3C, fig. 4, 5.

At Site 289 this species may have been overlooked at levels above the Thyrsocyrtis bromia Zone. At other DSDP sites the upper limit of the species seems to be considerably higher than that reported here (A. Sanfilippo, personal communication).

\section{Lychnocanoma amphitrite Foreman}

Foreman, 1973, plate 11, fig. 10.

Riedel and Sanfilippo, 1971, plate 3C, fig. 1, 2.

Included in this species is the form with vestigial feet (Riedel and Sanfilippo, 1971, plate 2C, fig. 2).

\section{Lychnocanoma bellum (Clark and Campbell)}

Lychnocanoma elongata (Riedel)

Riedel and Sanfilippo, 1971, plate 2F, fig. 2, 3.

Lychnocanoma trifolium Riedel and Sanfilippo

Riedel and Sanfilippo, 1971, plate 8, figs. 2, 3.

\section{Pterocanium prismatium Riedel}

Riedel and Sanfilippo, 1971, plate 8, fig. 1.

This species is so scarce at Site 289 throughout its previously reported range that no reliability can be placed on the limits of range recorded in this account. At Site 289 its very short apparent range immediately succeeds the extinction of $S$. peregrina. 
Phormocyrtis embolum (Ehrenberg)

Riedel and Sanfilippo (in press), plate 8, fig. 13.

Phormocyrtis striata striata Brandt

Foreman, 1973, plate 7, fig. 5, 6, 9.

Phormocyrtis striata exquisita (Kozlova)

Foreman, 1973, plate 7 , fig. 1-4, 7, 8; plate 12, fig. 5 .

Rhopalocanium ornatum Ehrenberg

Foreman, 1973, plate 10, fig. 9, 10; plate 12, fig. 3 .

Sethochytris babylonis (Clark and Campbell) Group

Riedel and Sanfilippo, 1971, plate 3b, fig. 13.

Sethochytris triconiscus Haeckel (?)

Riedel and Sanfilippo (in press), plate 9, fig. 7.

Stichocorys armata (Haeckel)

Riedel and Sanfilippo, 1971, plate 2E, fig. 13-15.

This species was noted through only a small thickness at Site 289, but it was not searched for routinely and may have been overlooked at other horizons.

Stichocorys delmontensis (Campbell and Clark)

Riedel and Sanfilippo, 1971, plate 1F, fig. 5-7; plate 2E, fig. 10, 11.

\section{Stichocorys peregrina (Riedel)}

Riedel and Sanfilippo, 1971, plate 1F, fig. 2-4.

The reported evolutionary transition between $S$. delmontensis and $S$. peregrina was found to be extremely difficult to place with any reliability at Site 289. This is due to the existence of late $S$. delmontensis morphotypes (Riedel and Sanfilippo, 1971, plate 1F, fig. 5) which are perfectly gradational with the $S$. peregrina morphotype and which dominate Stichocorys populations at levels where the transition has been reported. In this account, typical $S$. delmontensis is considered to be a form in which the abdomen, annular or conical, is noticeably wider than any other segment, and in which the post-abdominal segments are relatively poorly developed. Such a morphotype is clearly distinct from typical $S$. peregrina in which the fourth segment is also well developed, so that the first four segments together comprise a unit of roughly elliptical to conical outline, with the more posterior segments, ususally thinner walled, comprising a parallel-sided tube. However, the existence of the wholly intergradational populations of the late Ommatartus antepenultimus Zone and previously reported Ommatartus penultimus Zone makes the evolutionary transition a most unsatisfactory datum which is unlikely to be determined consistently in sequences of closely spaced samples. Further, the typical $S$. peregrina morphotype appears to originate earlier and occur without the typical $S$. delmontensis morphotype at some relatively high-latitude sites (see above). During the latter part of its range $S$. peregrina shows a marked "Cyrtocapselloid" trend, in that the aperture of the fourth segment becomes restricted and the more posterior segments may be very weak and narrow. It seems possible that this trend, in considerably earlier Stichocorys populations, may account for occasional atypical Cyrtocapsella like specimens noted.

\section{Stichocorys wolffii Haeckel}

Riedel and Sanfilippo, 1971, plate 2E, fig. 8, 9.

In the present account $S$. wolffii is considered to differ from $S$. delmontensis in having at least $50 \%$ of the thoracic pores closed or virtually closed, giving the thorax a distinctly hyaline appearance. In the most characteristic examples virtually all the pores are closed (Riedel and Sanfilippo, 1971, plate 2E, fig. 9; Riedel, 1957, plate 4, fig. 6). Rarely, closure extends to the abdomen so that the greater part of the shell is more or less hyaline.

So defined the $S$. wolffii morphotype at all levels of its occurence is perfectly gradational with contemporaneous $S$. delmontensis morphotypes, though the majority of $S$, wolffii specimens are more slender than the most typical $S$. delmontensis. As previously reported (Riedel and Sanfilippo, 1971, p. 1595) in DSDP materials, Site 289 contains a segment throughout which $S$. wolffii clearly predominates numerically over $S$. delmontensis, this segment being preceded and succeeded by segments in which $S$. delmontensis is predonimant. The most characteristic $S$. wolffii morphotype is restricted to the $S$. wolffii dominated segment. The levels of population change are comparatively easily recognizable datums at Site 289 . However, the observed morphologic gradation between $S$. wolffii and $S$. delmontensis morphotypes, and the reversible dominance of the former might suggest that " $S$. wolffii" is no more than a dimorph of $S$. delmontensis, its abundance being determined by local environmental factors. At the high-latitude DSDP Site 53, $S$. wolffii appears to persist in relative abundance to considerably higher levels than it reaches in comparable abundance at Site 289 (Kling, 1971, p. 1076).

Theocorys anaclasta Riedel and Sanfilippo

Foreman, 1973, plate 5, fig. 14, 15.

\section{Theocorys spongoconum Kling}

Kling, 1971, plate 5, fig. 6. Riedel and Sanfilippo, 1971, plate 2F, fig. 4.

In this account only specimens with a very finely spongy, opaque abdominal wall have been included in this species. So defined, the species has a markedly discontinuous range.

Theocotyle cryptocephala cryptocephala (Ehrenberg)

Foreman, 1973, plate 4, fig. 6, 7; plate 12, fig. 18.

Theocotyle cryptocephala nigriniae Riedel and Sanfilippo

Foreman, 1973, plate 4, fig. 1-5; plate 12, fig. 17.

\section{Theocotyle ficus (Ehrenberg)}

Foreman, 1973, plate 4, fig. 16-20

\section{Thyrsocyrtis bromia Ehrenberg \\ (Plate 1, Figures 12-14, 19-21)}

Riedel and Sanfilippo, 1971, plate 8, fig. 6.

Sufficient specimens of intermediate morphology were found at Site 286 to confirm the earlier suggestion (Riedel and Sanfilippo, 1970) that this species evolved from Thyrsocyrtis rhizodon. In this account, specimens included in $T$. bromia have the majority of abdominal pores at least some three times the size of the thoracic pores. Early specimens from the lowest levels of the $T$. bromia Zone have relatively slender abdomens and frequently possess marked, pointed, triangular feet (Plate 1). At both Sites 286 and 289 the uppermost range of $T$. bromia is characterized by the dominant presence of a more robust morphotype with almost spherical abdomen, proportionally fewer and larger abdominal pores and feet reduced to broad lappets or low undulations or-in the most distinctive variant-with feet completely missing (Plate 1). Change in populations with time appears similar to that reported by Dinkelman (1973).

\section{Thyrsocyrtis hirsuta hirsuta (Krasheninnikov)}

Foreman, 1973, plate 3, fig. 3-8.

\section{Thyrsocyrtis hirsuta tensa Foreman}

Foreman, 1973, plate 3, fig. 13-16.

\section{Thyrsocyrtis rhizodon Ehrenberg}

(Plate 1, Figures 15, 22, 23)

Foreman, 1973, plate 3, fig. 1, 2.

\section{Thyrsocyrtis tetracantha (Ehrenberg)}

Riedel and Sanfilippo (in press), plate 11, fig. 3. 4.

\section{Thyrsocyrtis triacantha (Ehrenberg) (Plate 1, Figure 18)}

Foreman, 1973, plate 12, fig. 9-11.

Riedel and Sanfilippo (in press), plate 8, fig. 2, 3.

The most characteristic $T$. tetracantha and $T$. triancantha morphotypes exemplified by the figured specimens cited above are perfectly distinct. Positioning of the $T$. triacantha $\rightarrow T$. tetracantha transition is complicated, however, by the existence of intermediate specimens with the abdominal rim weak or absent-as in $T$. tetracantha-but with only three feet, often weak and of unequal strength. For tabulation purposes such specimens with three unequally 
developed feet have been ignored, as have specimens in which there is a suggestion of four feet, but in which all feet are very weakly developed.

\author{
Thyrsocyrtis sp. Form A. \\ (Plate 1, Figures 16, 17, 25)
}

This designation is used for specimens somewhat similar to $T$. triacantha in which the abdomen is wide and inflated and the three long feet are three bladed. The form may be the one figured by Riedel and Sanfilippo (1970) plate 8, fig. 4. Presence of specimens with unbladed or partly unbladed feet (Plate 1, Figure 16) at some horizons suggests a close phylogenetic relation to $T$. triacantha, and at Site 289 Form A becomes more abundant than $T$. triacantha and ultimately completely replaces it in the upper part of $T$. bromia Zone OS.35. Form A was not noticed at Site 286 and may be absent.

\section{Carpocanistrum azyx Sanfilippo and Riedel}

Sanfilippo and riedel, 1973, plate 35 , fig. 9.

Carpocanopsis bramlettei Riedel and Sanfilippo

Riedel and Sanfilippo, 1971, plate 2G, fig. 8-14.

\section{Carpocanopsis cingulata Riedel and Sanfilippo}

Riedel and Sanfilippo, 1971, plate 2G, fig. 17-21; plate 8, fig. 8 .

Both the top and the bottom of the range of this species at Site 289 are rather indefinite. The most useful datum is the level of abrupt disappearance of the distinctive large form at the top of C. costata Zone, OS.18. Above this level the species is represented, if at all, only by sporadic small specimens of somewhat uncertain identity.

\section{Carpocanopsis favosa (Haeckel)}

Riedel and Sanfilippo, 1971, plate 2G, fig. 15, 16; plate 8, fig. 9, 11.

\section{Anthocyrtidium Haeckel spp.}

No attempt has been made in this report at specific identification of Anthocyrtidium spp., though at least some forms seem to have comparatively short ranges at Site 289 and could be of biostratigraphic utility. "Anthocyrtidium sp." has been used for any form with rather elongate cephalis, campanulate thorax terminating in a more or less well-defined peristome and lacking a true abdomen. The peristome can vary from a simple annular band of variable depth to a band with very marked terminal teeth. In practically all Anthocrytidium so defined, the perforate thorax terminated with a circlet of outwardly and downwardly directed teeth, very variable in strength.

The earliest ( $L$. elongata Zone) species detected at Site 289 is a relatively robust form with simple peristome, perhaps identical with Sanfilippo et al. (1973), plate 6, fig. 9. The genus persists at least to the Pliocene.

An interesting feature is the markedly fluctuating abundance of this genus at Site 289. Discontinuities in the range indicated in the Events Table (Figure 4 ) are at present only tentatively placed, but provide a rough guide to relative abundance in different segments.

\section{Calocycletta spp.}

This heading in tabulations has been used to indicate the presence of the genus in samples where specimens cannot be identified to species or where time has not permitted any such attempt.

\section{Calocycletta caepa Moore}

Sanfilippo and Riedel 1974, plate 3, fig. 8.

Through the uppermost part of the range of Calocycletta this is probably the only species present. The morphotypic base of the species was found difficul to place at Site 289.

\section{Calocycletta costata (Riedel)}

Riedel and Sanfilippo, 1971, plate 2H, fig. 12-14.

\section{Calocycletta virginis Haeckel}

Riedel and Sanfilippo, 1971, plate 2H, fig. 5-11

The actual morphotypic base of this species may well be lower at Site 289 than the level at which it is recorded. Early specimens of $C$. virginis aspect, however, invariably have the diagnostic feet dissolved away.
Podocyrtis chalara Riedel and Sanfilippo

Riedel and Sanfilippo, 1970, plate 12, fig. 2, 3.

Podocyrtis goetheana (Haeckel)

Riedel and Sanfilippo (in press), plate 11, fig. 6.

\section{Podocyrtis mitra Ehrenberg}

Riedel and Sanfilippo, 1970, plate 11, fig. 5, 6.

Podocyrtis sinuosa Ehrenberg (?)

Riedel and Sanfilippo, 1970, plate 11, fig. 3, 4.

\section{Theocyrtis annosa (Riedel) Group}

The base of this species may have been recorded at Site 289 at a level which is relatively lower than that previously recorded. Three variants are tabulated:

Theocyrtis annosa Form A. The earliest $T$. tuberosa Zone specimens: very delicately ribbed, usually rare and often represented by only fragmentary specimens.

Theocyrtis annosa Form B. Specimens with more pronounced ribbing and a suggestion that the shell is molded into broad, raised, longitudinal segments-identical with Riedel and Sanfilippo, 1971, plate $3 \mathrm{D}$, fig. 13. The first appearance is higher than the morphotypic base of Form A.

Theocyrtis annosa Form C. Larger specimens, lacking the suggestions of longitudinal segmentation, identical with Riedel and Sanfilippo, 1971, plate $2 \mathrm{H}$, fig. 4; plate $3 \mathrm{D}$, fig. 12 . The first appearance is higher again than that of Form B, and it is probable that only Form C persists to the extinction level of $T$. annosa group. In the highest part of its range Form $\mathrm{C}$ shows a tendency to reduction in rib strength and reversion to a morphotype somewhat similar to Form A.

As noted elsewhere (Riedel and Sanfilippo, 1973, p. 711), at Site 289 the ranges of $T$. annosa Group and Theocyrtis tuberosa do not overlap. The phylogenetic relationships between successive Theocyrtis populations is far from clear. In the T. bromia Zone at Site 289 Theocyrtis specimens exist which are difficult to exclude from $T$. annosa Group.

\section{Theocyrtis tuberosa Riedel}

Riedel and Sanfilippo, 1971, plate 3D, fig. 14.

In the $T$. tuberosa Zone at Site 289 this is a distinctive species with a very well-marked morphotypic top. It was found impossible, however, to decide where the morphotypic base should be placed in the very variable Theocyrtis populations of the $T$. bromia Zone. Indications of the abundance of the genus at these levels at Site 289 are given by tabulating the frequencies under the heading "Theocyrtis species."

\section{Theocampe armadillo (Ehrenberg) Group}

Riedel and Sanfilippo, 1971, plate 3E, fig. 3-6.

\section{Theocampe mongolfieri (Ehrenberg)}

Riedel and Sanfilippo, 1971, plate 3E, fig. 13.

Late specimens tend to have smaller, more numerous pores than those of the figured specimen cited here.

\section{Thoecampe pirum (Ehrenberg)}

Riedel and Sanfilippo, 1971, plate 3E, fig. 10, 11.

\section{Acrobotrys spp.}

Under this heading are tabulated all cannobotryids with less than or more than three tubes. Most commonly two tubes only are present, but a highly distinctive four-tubed form (Plate 2, Figure 29), probably of very short range was noted in the $C$. virginis Zone of Site 289 (OS.21-22). In the earliest noted Acrobotrys spp. specimens (D. ateuchus Zone, OS-26) the two tubes are closed.

\section{Acrobotrys tritubus Riedel}

Riedel and Sanfilippo, 1971, plate 15, fig. 19, 20.

\section{Botryocyrtis spp.}

Riedel and Sanfilippo, 1971, plate 15, fig. 1-11; plate 25, fig. 10-12; plate $3 \mathrm{~F}$, fig. 7 . 


\section{Botryopyle spp.}

The designation is used very broadly for cannobotryids, lacking prominent tubes, in which the cephalis is markedly eccentric with respect to the shell outline.

\section{Centrobotrys gravida Moore}

Moore, 1971, plate 5, fig. 8.

\section{Centrobotrys petrushevskayae Sanfilippo and Riedel}

(Plate 2, Figures 23-25)

Sanfilippo and Riedel, 1973, plate 36, fig. 12, 13.

\section{Centrobotrys thermophila Petrushevskaya}

Riedel and Sanfilippo, 1971, plate 1J, fig. 27-31; plate 2J, fig. 19; plate $3 \mathrm{~F}$, fig. 14.

This name is restricted to specimens in which the shell is virtually entirely poreless.

\section{Centrobotrys cf. thermophila}

(Plate 2, Figures 26-28)

This form is morphologically and, apparently, phyllogenetically intermediate between typical $C$. petrushevskayae and typical $C$. thermophila. The shell is less porous and commonly slightly larger than that of $C$. petrushevskayae, in which the pores are more evenly distributed and more closely spaced. The evolutionary transition from $C$. petrushevskayae to $C$. cf. thermophila is fairly distinct at Site 289 . The Centrobotrys population immediately prior to the transition is figured (Plate 2).

Tepka perforata Sanfilippo and Riedel

Sanfilippo and Riedel, 1973, plate 6, fig. 18-20.

\section{ACKNOWLEDGMENTS}

The writer is especially grateful to William Riedel and Annika Sanfilippo for patiently introducing him to the Cenozoic Radiolaria and for their help and Jean Westburg's help and advice as work proceeded. Thanks are due to Stanley Kling and Robert Goll for discussion of specific problems; to Jim Harrington and Bryonie Harker for invaluable help with shipboard and laboratory work, respectively; and to Tsune Saito for discussion of general stratigraphic problems. The University of Keel, financially supported Miss Harker's work and the writer is also most grateful to the Deep Sea Drilling Project for their generous support of his three periods of work and consultation at Scripps.

\section{REFERENCES}

Berggren, W.A., 1972. A Cenozoic time-scale-some implications for regional geology and palaeobiogeography: Lethaia, v. 5, p. 206.

Burns, R.E., Andrews, J.E., et al., 1973. Initial Reports of the Deep Sea Drilling Project, Volume 21: Washington (U.S. Government Printing Office).

Dinkelman, M.G., 1973. Radiolarian stratigraphy: Leg 16, Deep Sea Drilling Project. In Van Andel, T.H., Heath, R.G., et al., Initial Reports of the Deep Sea Drilling Project, Volume 16: Washington (U.S. Government Printing Office), p. 747-814.

Edwards, A.R., 1973. Southwest Pacific regional unconformities encountered during Leg 21 , In Burns, R.E., Andrews, J.E. et al., Initial Reports of the Deep Sea Drilling Project, Volume 21: Washington (U.S. Government Printing Office), p. 701-720.
Foreman, H.P., 1973. Radiolaria of Leg 10 with systematics and ranges for the families Amphipyndacidae, Artostrobiidae, and Theoperidae. In Worzel, J.L., Bryant, W., et al., Initial Reports of the Deep Sea Drilling Project, Volume 10: Washington (U.S. Government Printing Office), p. 407-474.

Goll, R., 1972. Leg 9 synthesis, Radiolaria. In Hays, J.D., Initial Reports of the Deep Sea Drilling Project, Volume 9: Washington (U.S. Government Printing Office), p. 9471058 .

Hays, J.D., Saito, T., Opdyke, N.D., and Burckle, L.H., 1969. Pliocene-Pleistocene sediments of the Equatorial Pacific: their paleomagnetic, biostratigraphic and climatic record: Geol. Soc. Am. Bull., v. 80, p. 1481-1514.

Kling, S.A., 1971. Radiolaria: Leg 6 of the Deep Sea Drilling Project. In Fischer, A.G., Heezan, B.C., et al., Initial Reports of the Deep Sea Drilling Project, Volume 6: Washington (U.S. Government Printing Office), p. 10691117.

1973. Radiolaria from the eastern North Pacific, Deep Sea Drilling Project, Leg 18, In Kulm, L.D., von Huene, R., et al., Initial Reports of the Deep Sea Drilling Project, Volume 18: Washington (U.S. Government Printing Office), p. 617-672.

Moore, T., 1971. Radiolaria. In Tracey, J.I., Jr., Sutton, G.H., et al., Initial Reports of the Deep Sea Drilling Project, Volume 8: Washington (U.S. Government Printing Office), p. 727-775.

Nigrini, C.A., 1971. Radiolarian zones in the Quaternary of the Equatorial Pacific Ocean. In Funnell, B.M. and Riedel, W.R. (Eds.), The Micropaleontology of Oceans: Cambridge (Cambridge Univ. Press), p. 443-461.

Riedel, W.R., 1957. Radiolaria: a preliminary stratigraphy. In Pettersson, H. (Ed.), Rept. Swedish Deep-Sea Exped. 19471948, Vol. VI, Göteborg, p. 61-96.

1959. Oligocene and lower Miocene Radiolaria in tropical Pacific sediments: Micropaleontology, v. 5, p. 285302.

Riedel, W.R. and Sanfilippo, A., 1971. Cenozoic Radiolaria from the Western tropical Pacific, Leg 7. In Winterer, E. L., et al., Initial Reports of the Deep Sea Drilling Project, Volume 7: Washington (U.S. Government Printing Office), p. $1529-1672$.

1973. Cenozoic Radiolaria from the Caribbean, Deep Sea Drilling Project, Leg 15, In Edgar, N.T., Saunders, J.B., et al., Initial Reports of the Deep Sea Drill ing Project, Volume 15: Washington (U.S. Government Printing Office), p. 705-751.

, in press. Cenozoic Radiolaria. In Ramsay, A.T.S. (Ed.) Oceanic micropalaeontology.

Sanfilippo, A. and Riedel, W.R., 1970. Post-Eocene "closed" theoperid Radiolarians: Micropaleontology, v. 16, p. 446462.

1973. Cenozoic Radiolaria (exclusive of Theoperids, Artostrobiids and Amphipyndacids) from the Gulf of Mexico, Deep Sea Drilling Project. Leg 10. In Worzel, J.L. Bryant, W., et al., Initial Reports of the Deep Sea Drilling Project, Volume 10: Washington (U.S. Government Printing Office, p. 475-612.

1974. Radiolaria from the west central Indian Ocean and Arabian Sea, DSDP Leg 24. In Initial Reports of the Deep Sea Drilling Project, Volume 24: p. 997-1036.

Sanfilippo, A., Burckle, L.H., Martini, E., and Riedel, W.R., 1973. Radiolarians, diatoms, silicoflagellates and calcareous nannofossils in the Mediterranean Neogene: Micropaleontology, v. 19, p. 209-234. 


\section{PLATE 1}

(All figures $\times 140$ except $9-11$ at $\times 55$ )

Figures 1, 2 Cannartus bassanii. 289-83, CC R(a). Z48.

Figures 3-6 Ommatartus hughest Form A. 289-28-4, 90-95 R.
3. X34/2.
4. $\mathrm{T} 45 / 4$.
5. T46.
6. R46.

Figures 7, 8 Lithocycliaangusta Form A. 289-94, CC R. W32/4.

Figures 9-11 Dorcadospyris circulus (dentate)

9. 289-76, CC R. N36/4.

10. 289-89, CC R(a). W35/2.

11. 289-89, CC R(a). E43.

Figures 12, 13 Thyrsocyrtis bromia. Late inflated form. 289-106, CC R(a).

12. $\mathrm{K} 61 / 4$.

13. $061 / 2$.

Figures 14, 19, Thyrsocyrtis bromia.

20,21

14. 289-106, CC R. K45/1.

19. 289-107-1, 135-140 cm R(c). K42/1.

20. 289-107, CC (2) R. W57/3.

21. 289-107, CC (2) R. Z63/1.

Figures 15, 22, Thyrsocyrtis rhizodon.

23

15, 289-106, CC R. 45/1

22. 289-107, CC (2) R. F35.

23. 289-107, CC R. L58/4.

Figures 16, 17, Thyrsocyrtis sp. Form A. 289-106, CC R.

25

16. K52.

17. $\mathrm{Z} 59 / 3$.

25. V $58 / 1$.

Figure 18 Thyrsocyrtis triacantha. 289-107, CC R. F47.

Figure 24 Thyrsocyrtis ? rhizodon. With horn similar to $T$. bromia. 286-17-4, 40-45 cm $\mathrm{Ph}(\mathrm{c})$. 040/2. 
PLATE 1
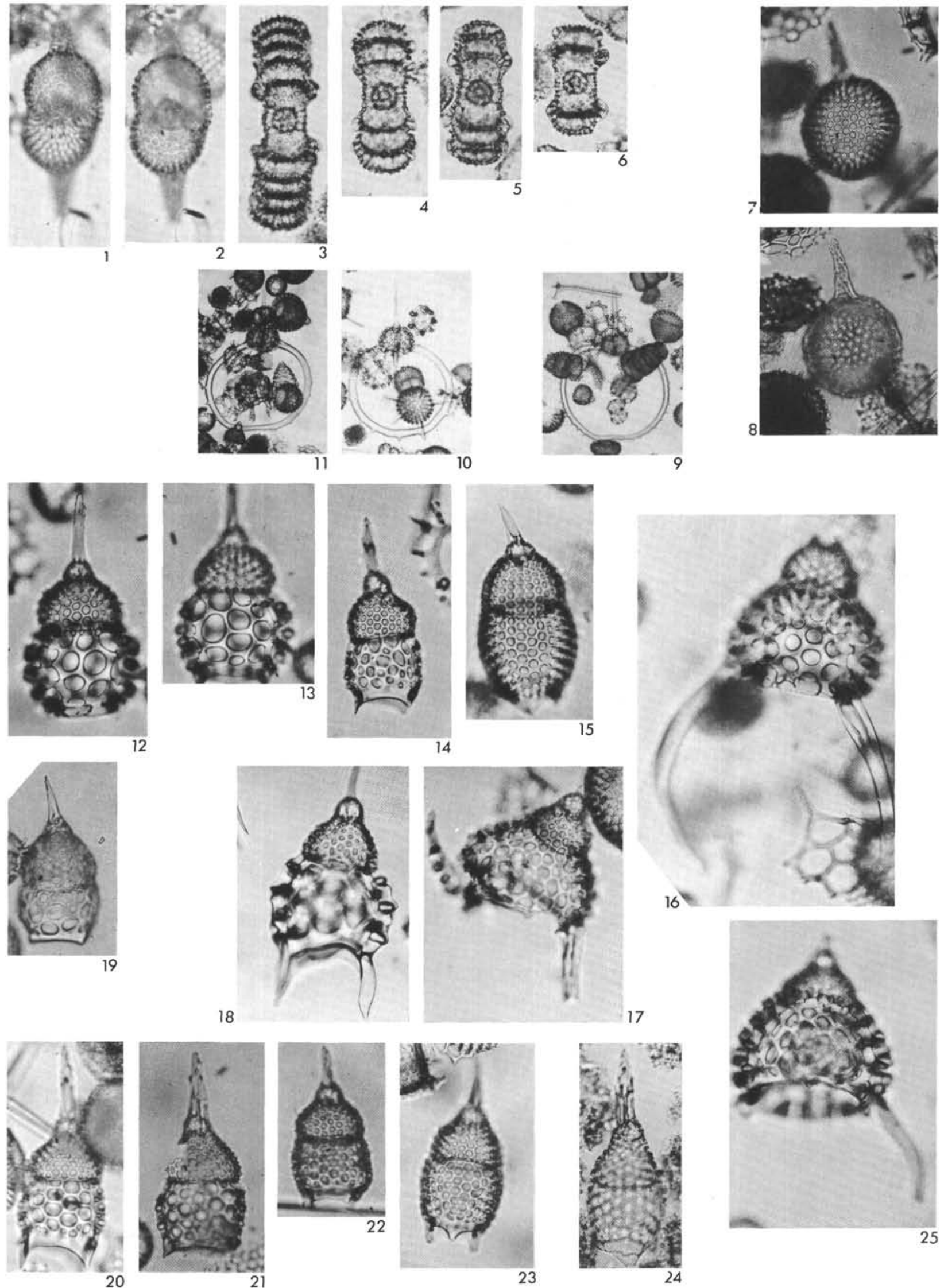


\section{PLATE 2}

Arrows indicate decreasing age of groups of Eucyrtidium spp. and Cyrtocapsella spp. Figures 23-28 illustrate the Centrobotrys population of 289-89, CC, slightly below the level of transition $C$. petrushevskayae $\rightarrow C$. $\mathrm{cf}$. thermophilla. All figures $\times 140$ except 29 at $\times 300$.

Figures 1-3, 5-8, Cyrtocapsella cornuta.

10,16
1. 289-40, CC R. D44/3.
2. 289-40, CC R. Z54/3.
3. 289-40, CC R. Z67/3.
5. 289-51-3, 70-75 cm R. W58/2.
6. 289-51-3, 70-75 cm R. W53/2.
7. 289-51-3, 70-75 cm R. W59.
8. 289-68, CC R. F50/3.
10. 289-67, CC R. L44/3.
16. $289-73-3,70-75 \mathrm{~cm} \mathrm{R} . \mathrm{Z62} / 4$.

Figure $4 \quad$ Cyrtocapsella aff. tetrapera. 289-51-31, 70-75 cm R. X53/1.

Figures 9, 13-15 Cyrtocapsella tetrapera.

9. 289-68, CC R. N41/2.

13. $289-73-3,70-75 \mathrm{~cm} \mathrm{R}$. Z62/4.

14. $289-73-3,70-75 \mathrm{~cm} \mathrm{R} . \mathrm{N} 29 / 2$

15. 289-73-3, 70-75 cm R. Z62/4.

Figures 11, 12 Cyrtocapsella tetrapera (ovoid) 289-67, CC R.

11. $\mathrm{V} 42 / 2$.

12. G34/2.

Figure $17 \quad$ Cyrtocapsella sp. 289-73-3, 70-75 cm R. 033/4.

Figures 18-22 Eucyrtidium sp.

18. 289-74-1, $70-75 \mathrm{~cm} \mathrm{Ra.} \mathrm{H40/1.}$

19. $289-74-1,70-75 \mathrm{~cm} \mathrm{Ra} . \mathrm{E} 32 / 3$.

20. 289-74-3, 70-75 cm Ra. L33.

21. 289-74-3, 70-75 cm Ra. M33.

22. $289-74-3,70-75 \mathrm{~cm} \mathrm{Ra} . \mathrm{F} 35 / 3$.

Figures 23-25 Centrobotrys petrushevskyae. 289-89, CC a.

23. Z54.

24. G39.

25. U62/2.

Figures 26-28 Centrobotrys cf. thermophilia. 289-89, CC Ra. 26. W44/1.

27. Z63.

28. Y49/4.

Figure 29 Acrobotrys sp. 289-63, CC Ra. F64/1. 
PLATE 2
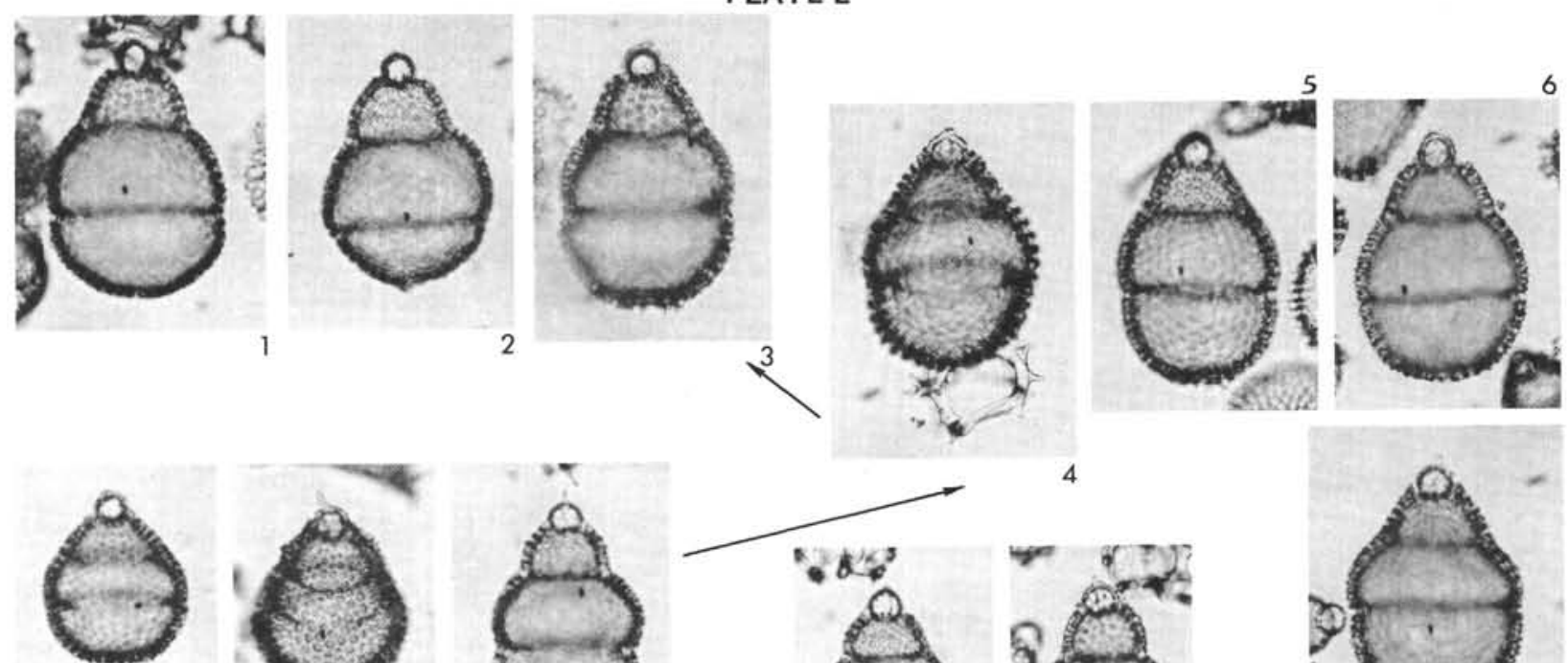

12
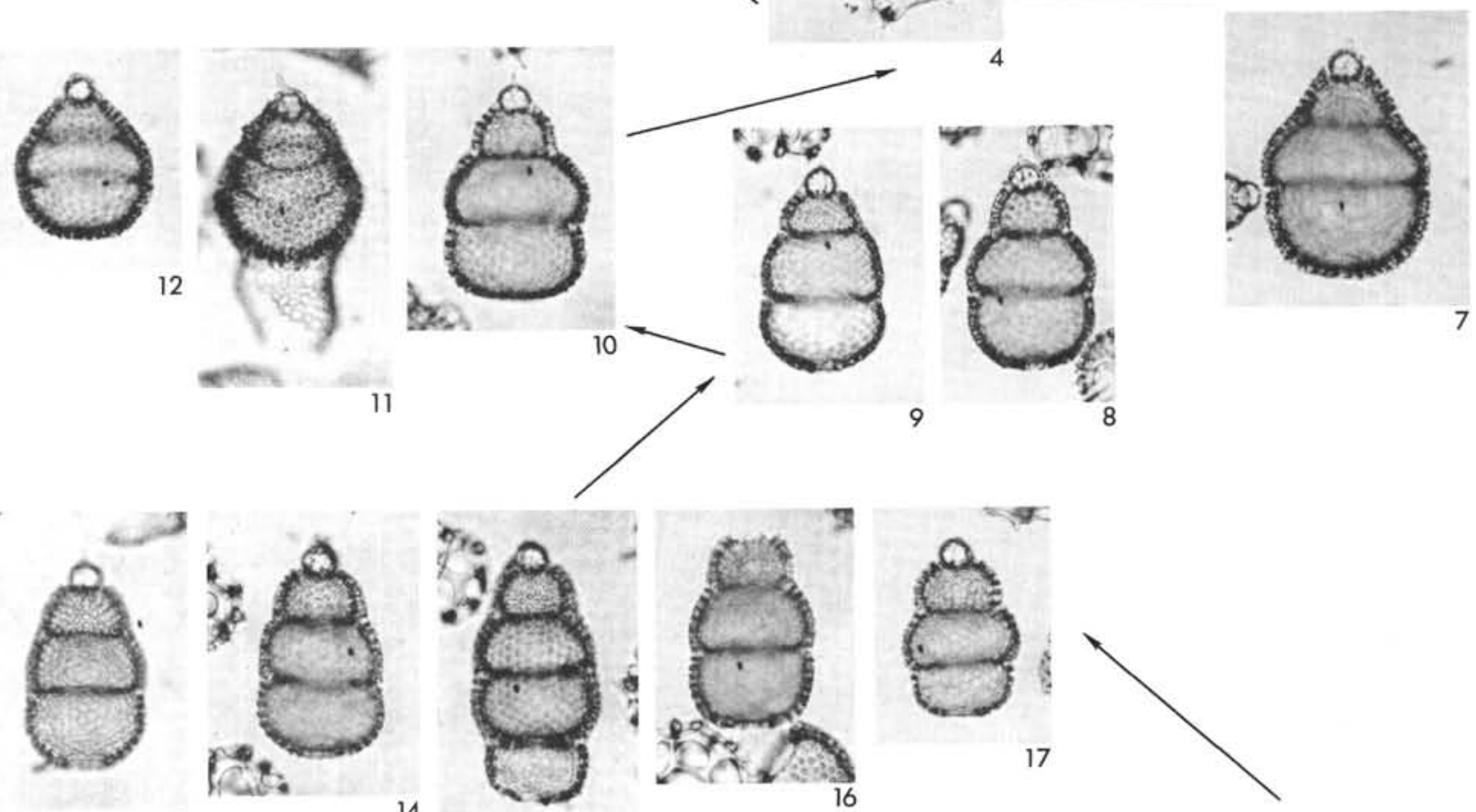

13
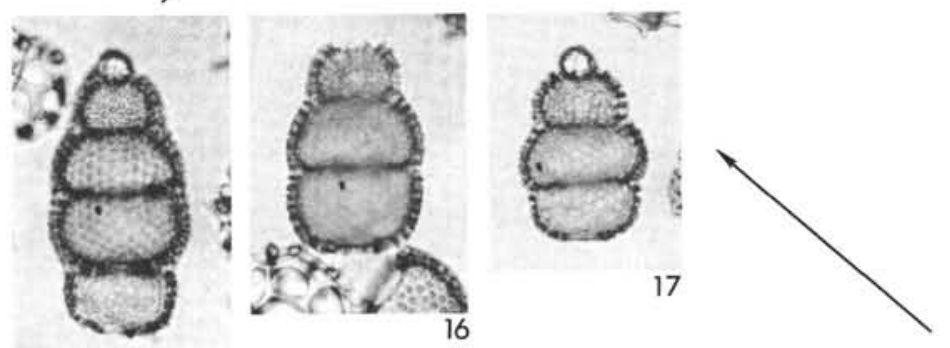

15
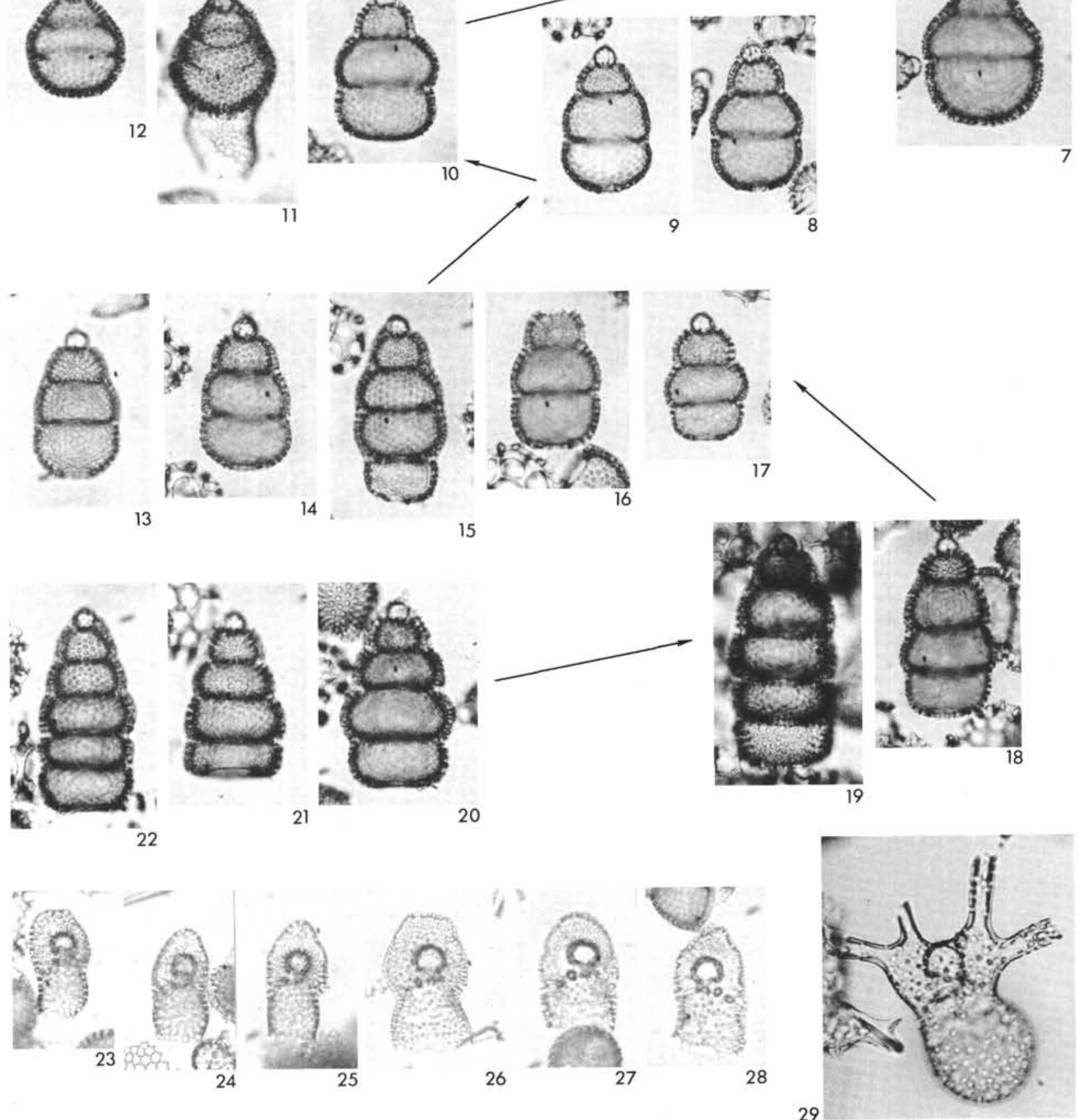